INEEL/EXT-99-01353

January 2000

\title{
OXIDATION, VOLATILIZATION, AND REDISTRIBUTION OF MOLYBDENUM FROM TZM ALLOY IN AIR
}

\author{
G. R. Smolik \\ D. A. Petti \\ S. T. Schuetz
}




\title{
Oxidation, Volatilization, and Redistribution of Molybdenum from TZM Alloy in Air
}

\author{
Galen R. Smolik \\ David A Petti \\ Stan T. Schuetz
}

Published January 2000

Idaho National Engineering and Environmental Laboratory Idaho Falls, Idaho 83415

Prepared for the U.S. Department of Energy Office of Energy Research Under the DOE Idaho Operations

Contract DE-AC07-99ID13727 


\begin{abstract}
The excellent high temperature strength and thermal conductivity of molybdenum-base alloys provide attractive features for components in advanced magnetic and inertial fusion devices. Refractory metal alloys react readily with oxygen and other gases. Oxidized molybdenum in turn is susceptible to losses from volatile molybdenum trioxide species, $\left(\mathrm{MoO}_{3}\right)_{\mathrm{m}}$, in air and the hydroxide, $\mathrm{MoO}_{2}(\mathrm{OH})_{2}$, formed from water vapor. Transport of radioactivity by the volatilization, migration, and re-deposition of these volatile species during a potential accident involving a loss of vacuum or inert environment represents a safety issue. In this report we present experimental results on the oxidation, volatilization and re-deposition of molybdenum from TZM in flowing air between 400 and $800^{\circ} \mathrm{C}$. These results are compared with calculations obtained from a vaporization mass transfer model using chemical thermodynamic data for vapor pressures of $\mathrm{MoO}_{3}(\mathrm{~g})$ over pure solid $\mathrm{MoO}_{3}$ and an expression for the vapor pressures of $\mathrm{MoO}_{2}(\mathrm{OH})_{2}$ from the literature. Calculations correlate well with experimental data. The volatilization process is dominated by $\mathrm{MoO}_{3}$ above $550^{\circ} \mathrm{C}$ and by $\mathrm{MoO}_{2}(\mathrm{OH})_{2}$, formed from the small ingress of water vapor, at temperatures below $550^{\circ} \mathrm{C}$. Partial saturation of gaseous species of $\left(\mathrm{MoO}_{3}\right)$ near specimen surfaces accounts for observed reductions in volatilization rates at lower flow rates at $700^{\circ} \mathrm{C}$. We have thus demonstrated predictive capabilities of the model to account for volatilization as influenced by temperature, humidity (vapor content), and flow rate.
\end{abstract}

We obtained oxidation rates $(\mathrm{mm} / \mathrm{h})$ as indicated by the recession into the base metal. These rates which accounted for the concurrent processes of oxidation and volatilization showed trends similar to other refractory metals, namely, niobium and tantalum.

Deposition of $\mathrm{MoO}_{3}$ downstream at lower temperatures was calculated with a model using saturation ratios of $\left(\mathrm{MoO}_{3}\right)_{\mathrm{m}}$ within segmented regions. Calculated locations of peak distributions and maximums within the temperature gradients generally correlate reasonable well with experimental measurements. Scanning electron microscopy showed that deposits collected in a final filter consisted of small agglomerated particles. We might expect such nucleation, growth and agglomeration of particles to result from the supersaturation of the $\left(\mathrm{MoO}_{3}\right)_{\mathrm{m}}$ upon cooling during transport. Hydroxide molecules also decompose back into $\mathrm{MoO}_{3}(\mathrm{~s})$ and water vapor at low temperatures. These latter two processes and increased surface areas due to extensive crystal growth from $\left(\mathrm{MoO}_{3}\right)_{\mathrm{m}}$ are plausible explanations for differences in peak height and distribution predictions between the model and experiments..

The oxidation-driven mobilization data, along with activation calculations determining radioactive isotope inventories, were used to determine airborne dose rates. These calculations showed that site boundary doses from TZM alloy would be one to two orders of magnitude lower than tungsten at comparable temperatures. 


\section{SUMMARY}

In this report we present the results of experimental and modeling approaches used to define the oxidation, oxidation-driven vaporization, and re-condensation behavior of TZM alloy tested in air environments between 400 and $800^{\circ} \mathrm{C}$. Experimental procedures are presented in Section 2. This section describes the test system used to expose specimens at various temperatures and flow rates in an air environment. Included are descriptions of the system and procedures used to collect, quantify, and examine the volatilized and re-deposited oxide products.

Experimental results are presented in Section 3. This includes the integration of mass change and inductively coupled plasma-atomic emission spectroscopy (ICP-AES) results to account for the concurrent processes of oxygen pick-up and oxide volatilization. These integrations provide oxidation rates $(\mathrm{mm} / \mathrm{h})$, the relative amount of the oxide that is volatilized, and the mobilization rate of molybdenum $\left(\mathrm{g} / \mathrm{m}^{2}-\mathrm{h}\right)$. Features of the oxidized specimens based on physical appearance, optical metallography, scanning electron microcopy (SEM), and x-ray diffraction (XRD) are given in Section 3.2. Illustrations of re-deposited oxides are shown in Section 3.3. Detailed descriptions of deposited oxide products on various system components, the chemical analyses procedures, and ICP-AES results providing mass flux calculations and distribution information are given in Appendices A, B, and C, respectively.

Experimental results are discussed in Section 4. Oxidation rates, mechanisms and the relative amount volatized at various temperatures are compared to the available information in the literature in Sections 4.1 and 4.2. A description of our vaporization mass transfer model including the procedure to handle partial saturation of volatilizing oxide species near specimen surfaces is given in Section 4.3. The treatment for partial saturation helped to explain flow rates effects. In this section we also present equilibrium vapor pressures for both volatilizing polymers of $\left(\mathrm{MoO}_{3}\right)_{\mathrm{m}}$ and $\mathrm{MoO}_{2}(\mathrm{OH})_{2}$ as a function of temperature and various water vapor concentrations. The combined results from these two species, with $\mathrm{MoO}_{2}(\mathrm{OH})_{2}$ dominating at low temperatures and $\left(\mathrm{MoO}_{3}\right)_{\mathrm{m}}$ dominating at high temperatures, provide a very good correlation with experimental measurements. Our model predicting the re-deposition from $\left(\mathrm{MoO}_{3}\right)_{\mathrm{m}}$ vapors is described and compared with experimental molybdenum profiles in Section 4.4. The model provides good correlation with the locations of peak deposition for tests performed at and above $600^{\circ} \mathrm{C}$. Plausible reasons for differences between predicted and measured peak heights and subsequent deposition profiles include: 1) nucleation, growth, agglomeration, and transport of particles due to supersaturation of $\left(\mathrm{MoO}_{3}\right)_{\mathrm{m}}$ upon cooling, 2) extra surface areas for re-deposition resulting from crystal development, 3) the role of $\mathrm{MoO}_{2}(\mathrm{OH})_{2}$ in the mobilization process at lower temperatures. A comparative study showing mobility-based doses derived for TZM alloy and tungsten is given in Section 4.5. This comparison shows that doses from the activated products of TZM alloy are one to two orders lower than tungsten for similar accident conditions of a conceptual fusion device. 


\section{ACKNOWLEDGMENTS}

This work is supported by the U.S. Department of Energy, Office of Energy Research, under the DOE Idaho Operations Contract DE-AC07-94ID13223. The authors wish to acknowledge the contributions of J. D. Christian and D. L. Hagrman for their help with vapor pressure properties and interpretation of the vaporization mechanisms, respectively. 


\section{CONTENTS}

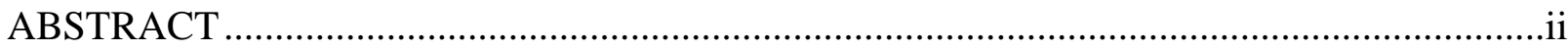

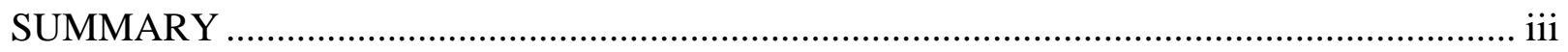

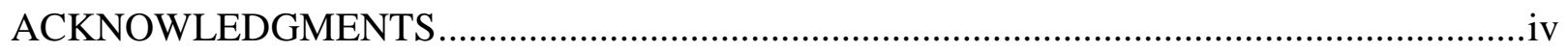

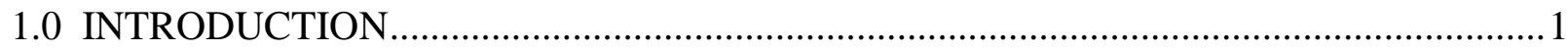

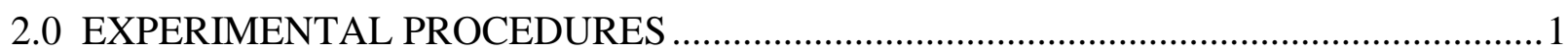

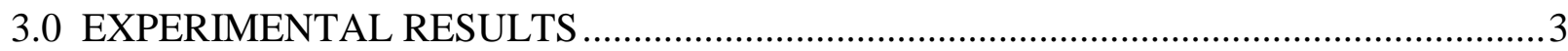

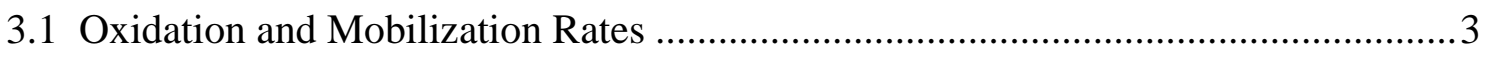

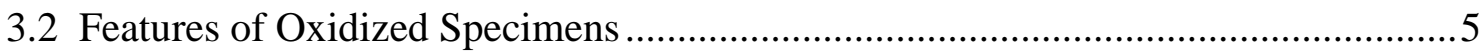

3.2.1 Specimen Appearance ...........................................................................

3.2.2 Microstructural Observations of Oxidized Specimens ....................................6

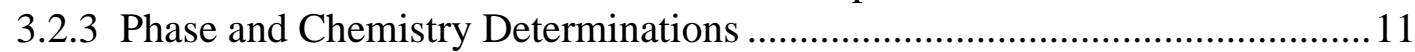

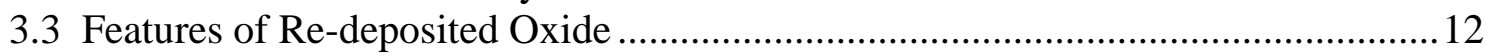

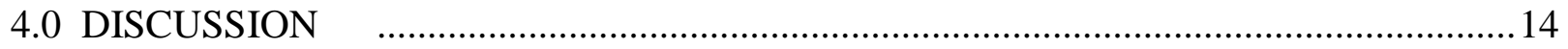

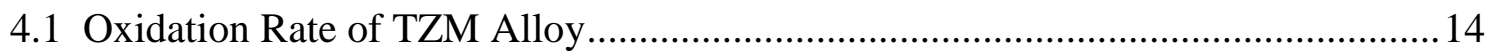

4.2 Volatilization Process from Oxidized TZM Alloy.................................................14

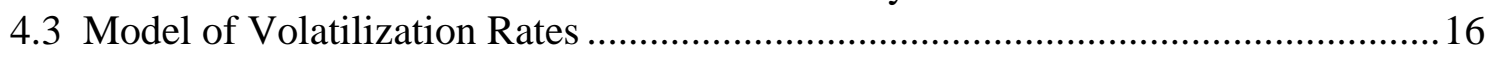

4.4 Model Re-deposition of Mobilized Molybdenum.................................................19

4.5 Mobility-Based Dose Derived from Oxidation Driven Volatility ............................26

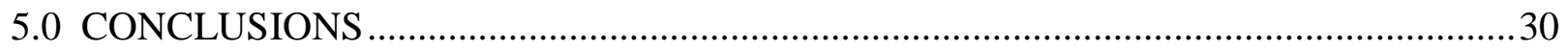

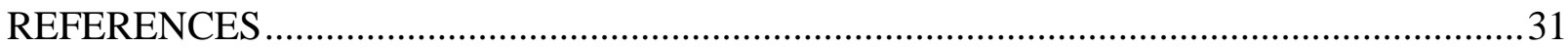

Appendix A: Descriptions of Molybdenum Oxide Products Deposited in Quartz Test Components ............................................................................

Appendix B: Procedures for Cleaning the Molybdenum-Bearing Test Components and Processing the Solutions for ICP-AES Analyses .......................................... B-1

Appendix C: ICP-AES Analyses, Mass Flux Calculations, Molybdenum Distributions, and Temperature Profiles ......................................................... 


\subsection{INTRODUCTION}

The potential of high temperature strength has motivated much interest in the oxidation behavior of refractory metals. Many of these studies have been oriented toward extremely high temperatures, e.g., up to $1700^{\circ} \mathrm{C}$, often under vacuum or environments with low oxygen activities [1, 2.4. Studies [15]6] on molybdenum at lower temperatures in high levels of oxygen report: 1) parabolic rate law at 250 to $450^{\circ} \mathrm{C}$, 2) linear behavior above $400^{\circ} \mathrm{C}$, 3) a role of $\mathrm{MoO}_{2}$ and other oxides $\left(\mathrm{MoO}_{\mathrm{Z}}\right)$, where $2<\mathrm{Z}<3$, between 450 to $650^{\circ} \mathrm{C}$. At temperatures above $650^{\circ} \mathrm{C}$, oxidation rates are largely influenced by the high rates of the vaporization of the various polymers of $\mathrm{MoO}_{3}$. Water vapor will also react with $\mathrm{MoO}_{3}(\mathrm{~s})$ to form a volatile hydroxide. Vapor pressures of this $\mathrm{MoO}_{2}(\mathrm{OH})_{2}$ species have been documented by Speiser and St. Pierre [6]. We performed this study to explore conditions more typical to future fusion devices and to demonstrate predictive capabilities of a vaporization mass transport model. The model had provided excellent mass transport predications for the highly volatile species produced in the tungsten-steam system. [7]

\subsection{EXPERIMENTAL PROCEDURES}

We tested specimens of TZM alloy between 400 and $800^{\circ} \mathrm{C}$ in air flowing at a rate of $1000 \mathrm{sccm}$. Flow rates were varied from $10 \mathrm{sccm}$ to $2500 \mathrm{sccm}$ for tests at $700^{\circ} \mathrm{C}$. Gas velocities for these flow rates at $700^{\circ} \mathrm{C}$, the pressure at the INEEL, and the test chamber cross section ranged from 0.033 to 8.3 meters per minute. The specimens were prepared from a $22-\mathrm{mm}$ diameter bar made by vacuum arc casting and then hot extrusion. The composition was $\mathrm{Mo}-99.25 \mathrm{wt} \%, \mathrm{Ti}-0.50$ wt $\%, \mathrm{Zr}-0.102 \mathrm{wt} \%, \mathrm{C}-0.018 \mathrm{wt} \%$, Si $-0.0034 \mathrm{wt} \%$, Fe -0.001 wt $\%$, Ni -0.001 wt $\%$, $\mathrm{O}-0.0009 \mathrm{wt} \%$, and $\mathrm{N}-0.0005 \mathrm{wt} \%$. Disc-shaped specimens of either 1.75- or 3.5-mm thickness were sectioned from the bar. Surfaces were polished to a 600-grit finish.

The specimens were tested in a dual furnace arrangement as shown in Figure 1. The test system consisted of three regions, the reaction furnace, a transition zone, and a furnace in which deposition occurred. The dimensions of the quartz components in the system were as follows: reaction chamber $(4.0 \mathrm{~cm}$ I.D. x $36 \mathrm{~cm}$ long), the transition zone $(1.5 \mathrm{~cm}$ I.D. x $13 \mathrm{~cm}$ long), and the deposition tube $(1.5 \mathrm{~cm}$ I.D. $x$ 90 cm long). Air from a compressed cylinder flowed through a column of Drierite and was preheated to $400^{\circ} \mathrm{C}$ before passage into the reaction furnace containing the specimen. Upon exiting the reaction furnace the gas stream then passed through a transition zone and a three-zone furnace with a prescribed temperature gradient. Oxidation products transported from the specimen were re-deposited in these components downstream at temperatures between 800 and $25^{\circ} \mathrm{C}$. The quartz collection tube in the three-zone furnace was lined with sections of 1-in., or 3-in., long quartz tube. These were used to determine the distribution to the re-deposited molybdenum oxide products along the temperature gradient. A final filter of quartz wool was used to ensure the complete capture of products at the end of the collection tube. 


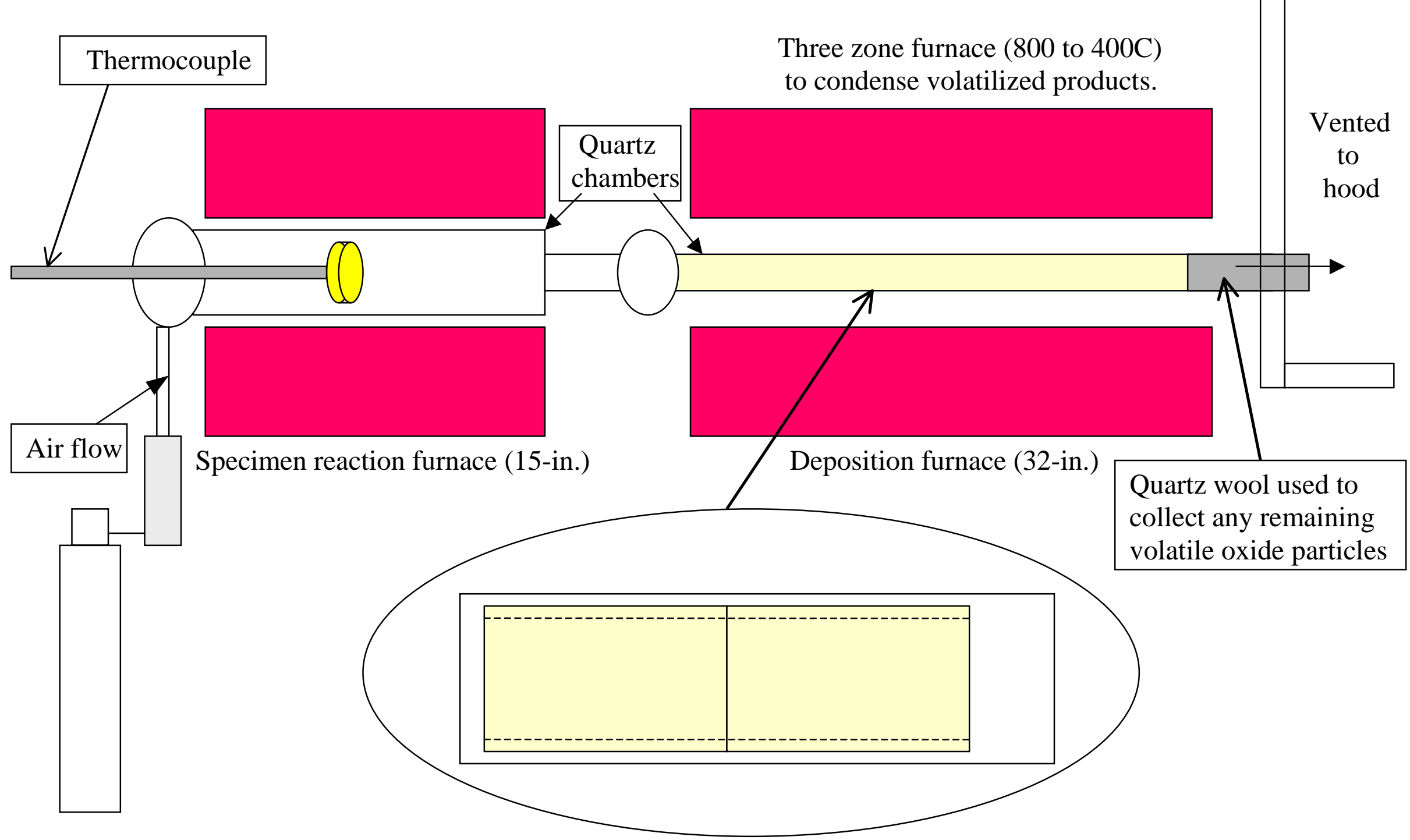

Figure 1. Schematic of test system to study the mobilization/deposition of $\mathrm{MoO}_{3}$ from TZM molybdenum alloy in flowing air. 
Specimens were weighed before and after testing to obtain mass change. The quartz components were visually inspected following the tests. Descriptions of the oxide products deposited on the components are given in Appendix A. The quartz components were then separately processed as described by the procedures in Appendix B. This involved cleaning the components with 2.9 molar $\mathrm{NH}_{4}(\mathrm{OH})$ solution to remove the molybdenum oxide products. The solutions were heated to drive off $\mathrm{NH}_{3}$ and then acidified with nitric acid and diluted to $100 \mathrm{ml}$ or $250 \mathrm{ml}$ samples. The diluted solutions were analyzed by inductively coupled plasma-atomic emission spectroscopy (ICP-AES). We examined oxidized specimens with optical metallography, scanning electron microcopy (SEM), and x-ray diffraction (XRD).

\subsection{EXPERMENTAL RESULTS}

3.1 OXIDATION AND MOBILIZATION RATES. The test matrix with temperatures, times, and flow rates, along with mass changes and total amounts of molybdenum transported as measured by ICP-AES are given in Table 1. Oxidation rates and molybdenum mass flux rates can be obtained from the data in Table 1. However, mass changes need to be corrected to allow for concurrent oxygen pick-up and losses by molybdenum oxide volatilization. For these calculations we assume that the oxidation process essentially produces molybdenum trioxide by the reaction: $\mathrm{Mo}+(3 / 2) \mathrm{O}_{2} \rightarrow \mathrm{MoO}_{3}$. The total mass of molybdenum $\left(\mathrm{M}_{\mathrm{t}}^{\mathrm{Mo}}\right)$ reacted can then be determined by the relationship expressed in Eq.(1):

$$
\left(\mathrm{M}_{\mathrm{t}}^{\mathrm{Mo}}\right)=\left(\mathrm{M}_{\mathrm{V}}^{\mathrm{Mo}}\right)+(96 / 48)\left[\Delta \mathrm{m}+\left(\mathrm{M}_{\mathrm{V}}^{\mathrm{Mo}}\right)\right] \text {, }
$$

where $\Delta \mathrm{m}$ is the mass change and $\left(\mathrm{M}_{\mathrm{V}}{ }^{\mathrm{Mo}}\right)$ is the amount of volatilized molybdenum as measured by ICP-AES. The results of these calculations are given in Table 2. We used these values to determined recession rates $(\mathrm{mm} / \mathrm{h})$ and the fraction of oxidized molybdenum that volatilized. Recession considered as the depth of alloy converted to oxide was calculated using $10.2 \mathrm{~g} / \mathrm{cm}^{3}$ as the density of molybdenum and initial surface area. We used metallography to measure recession rates $(\mathrm{mm} / \mathrm{h})$ for a limited number of specimens. Average mass flux values were obtained from the sum of the ICP-AES measurements for all system components for a given test, the initial surface area of the specimen, and the test duration. The detailed calculations from the ICP-AES measurements are reported in Appendix C. The calculations in Appendix $\mathrm{C}$ show the average mass flux from the specimen, molybdenum distributions, and temperature profiles. Essentially there was no indications of molybdenum mobilization at $400^{\circ} \mathrm{C}$. We use a flux value, which we refer to as the Engineering Maximum Flux Value (EMFV), at this temperature. It is determined from the ICP-EAS detection limit from a blank solution. The flux values at $500^{\circ} \mathrm{C}$ are orders of magnitude higher than the detection limit and more than ten times greater than the uncertainty based on ICP-AES limitations. A summary of the measurements and calculations refer to above are shown in Table 2. 
Table 1. Test matrix with mass changes and ICP-AES measurements.

\begin{tabular}{|c|c|c|c|c|c|c|c|c|}
\hline Specimen & $\begin{array}{c}\text { Temp., } \\
{ }^{\circ} \mathrm{C}\end{array}$ & $\begin{array}{c}\text { Flow rate, } \\
\text { sccm }\end{array}$ & $\begin{array}{c}\text { Time, } \\
\mathrm{h}\end{array}$ & $\begin{array}{c}\text { Initial } \\
\text { area,cm }{ }^{2}\end{array}$ & $\begin{array}{c}\text { Initial } \\
\text { weight, g }\end{array}$ & $\begin{array}{c}\text { Final } \\
\text { weight, } \mathrm{g}\end{array}$ & $\begin{array}{c}\text { Mass } \\
\text { change, g }\end{array}$ & $\begin{array}{c}\text { ICP-AES } \\
\text { total, g }\end{array}$ \\
\hline & & & & & & & & \\
\hline TZM14 & 400 & 1000 & 24 & 10.345 & 13.6641 & 13.6684 & 0.0043 & $1.5 \mathrm{E}-6(\mathrm{a})$ \\
\hline TZM15 & 500 & 1000 & 24 & 10.369 & 13.8827 & 13.94643 & 0.06373 & $1.02 \mathrm{E}-4$ \\
\hline TZM1 & 500 & 1000 & 24 & 9.101 & 6.6733 & 6.7429 & 0.0696 & $5.97 \mathrm{E}-5$ \\
\hline TZM16 & 550 & 1000 & 24 & 10.402 & 14.0636 & 14.4353 & 0.3717 & $9.04 \mathrm{E}-4$ \\
\hline TZM11 & 602 & 1000 & 8 & 10.235 & 13.15934 & 13.35724 & 0.19790 & $3.25 \mathrm{E}-3$ \\
\hline TZM7 & 599 & 1000 & 24 & 9.136 & 6.88303 & 7.65951 & 0.7765 & $3.56 \mathrm{E}-3$ \\
\hline TZM8 & 650 & 1000 & 8 & 9.123 & 6.8263 & 7.3607 & 0.5344 & $2.51 \mathrm{E}-2$ \\
\hline TZM4 & 699 & 10 & 2 & 8.994 & 6.1262 & 6.1887 & 0.0625 & $4.50 \mathrm{E}-3$ \\
\hline TZM17 & 700 & 10 & 8 & 10.311 & 13.4955 & 13.7485 & 0.2530 & $1.91 \mathrm{E}-2$ \\
\hline TZM5 & 699 & 50 & 2 & 9.111 & 6.7467 & 6.7988 & 0.0521 & $4.55 \mathrm{E}-3$ \\
\hline TZM18 & 700 & 50 & 8 & 10.326 & 13.5565 & 13.7589 & 0.2024 & $5.75 \mathrm{E}-2$ \\
\hline TZM10 & 699 & 100 & 2 & 9.112 & 6.71857 & 6.74414 & 0.02557 & $3.08 \mathrm{E}-2$ \\
\hline TZM6 & 700 & 500 & 2 & 9.075 & 6.4623 & 6.4560 & -0.0063 & $6.49 \mathrm{E}-2$ \\
\hline TZM12 & 700 & 1000 & 2 & 10.343 & 13.67683 & 13.67773 & 0.0009 & $5.43 \mathrm{E}-2$ \\
\hline TZM9 & 700 & 2500 & 2 & 9.069 & 6.52977 & 6.52907 & -0.0007 & $5.67 \mathrm{E}-2$ \\
\hline TZM3 & 750 & 1000 & 1 & 9.056 & 6.48254 & 6.1071 & -0.3754 & $3.46 \mathrm{E}-1$ \\
\hline TZM2 & 800 & 1000 & 1 & 9.150 & 6.9709 & 3.6501 & -1.9056 & $2.22 \mathrm{E}+0$ \\
\hline
\end{tabular}

(a) The value reported for $400^{\circ} \mathrm{C}$ is a maximum as established by the detection limit from ICP-AES.

Table 2. Oxidation and mass flux rates determined for molybdenum oxidation tests.

\begin{tabular}{|c|c|c|c|c|c|c|c|c|c|}
\hline Specimen & $\underset{{ }^{\circ} \mathrm{C}}{\text { Temp }}$ & $\begin{array}{l}\text { Flow } \\
\text { rate, } \\
\text { sccm }\end{array}$ & $\begin{array}{c}\text { Time } \\
\mathrm{h}\end{array}$ & $\begin{array}{l}\text { Total Mo } \\
\text { reacted, } \\
\mathrm{g}\end{array}$ & $\begin{array}{l}\text { Calculated } \\
\text { recession } \\
\text { rate, } \mathrm{mm} / \mathrm{h}\end{array}$ & $\begin{array}{l}\text { Measured } \\
\text { recession } \\
\text { rate, } \mathrm{mm} / \mathrm{h}\end{array}$ & $\begin{array}{l}\text { Fraction of } \\
\text { reacted Mo } \\
\text { volatilized }\end{array}$ & $\begin{array}{l}\text { Measured } \\
\text { mass flux } \\
\mathrm{g} /\left(\mathrm{m}^{2}-\mathrm{h}\right)\end{array}$ & $\begin{array}{l}\text { Predicted } \\
\text { mass flux } \\
\mathrm{g} /\left(\mathrm{m}^{2}-\mathrm{h}\right)\end{array}$ \\
\hline TZM14 & 400 & 1000 & 24 & 0.0086 & $3.40 \mathrm{E}-5$ & & $1.74 \mathrm{E}-4$ & 6.04E-5(a) & $8.22 \mathrm{E}-5$ \\
\hline TZM15 & 500 & 1000 & 24 & 0.1277 & $5.03 \mathrm{E}-4$ & & $8.00 \mathrm{E}-4$ & $4.10 \mathrm{E}-3$ & $2.97 \mathrm{E}-3$ \\
\hline TZM1 & 500 & 1000 & 24 & 0.1393 & $6.25 \mathrm{E}-4$ & & $4.30 \mathrm{E}-4$ & $2.73 \mathrm{E}-3$ & $2.97 \mathrm{E}-3$ \\
\hline TZM16 & 550 & 1000 & 24 & 0.7457 & $2.93 \mathrm{E}-3$ & & $1.21 \mathrm{E}-3$ & $3.62 \mathrm{E}-2$ & $2.28 \mathrm{E}-2$ \\
\hline TZM11 & 602 & 1000 & 8 & 0.4053 & $4.85 \mathrm{E}-3$ & & $8.02 \mathrm{E}-3$ & $3.97 \mathrm{E}-1$ & $2.97 \mathrm{E}-1$ \\
\hline TZM7 & 599 & 1000 & 24 & 1.5628 & $6.99 \mathrm{E}-3$ & $6.24 \mathrm{E}-3$ & $2.28 \mathrm{E}-3$ & $1.62 \mathrm{E}-1$ & $2.97 \mathrm{E}-1$ \\
\hline TZM8 & 650 & 1000 & 8 & 1.1434 & $1.54 \mathrm{E}-2$ & & $2.19 \mathrm{E}-2$ & $3.43 \mathrm{E}+0$ & $4.17 \mathrm{E}+0$ \\
\hline TZM4 & 699 & 10 & 2 & 0.1384 & $7.55 \mathrm{E}-3$ & & $3.25 \mathrm{E}-2$ & $2.50 \mathrm{E}+0$ & $7.06 \mathrm{E}-5$ \\
\hline TZM17 & 700 & 10 & 8 & 0.5631 & $6.69 \mathrm{E}-3$ & & $3.40 \mathrm{E}-2$ & $2.32 \mathrm{E}+0$ & $7.06 \mathrm{E}-5$ \\
\hline TZM5 & 699 & 50 & 2 & 0.1178 & $6.33 \mathrm{E}-3$ & & $3.86 \mathrm{E}-2$ & $2.50 \mathrm{E}+0$ & $4.60 \mathrm{E}-1$ \\
\hline TZM18 & 700 & 50 & 8 & 0.5745 & $6.85 \mathrm{E}-3$ & & $9.95 \mathrm{E}-2$ & $6.95 \mathrm{E}+0$ & $4.60 \mathrm{E}-1$ \\
\hline TZM10 & 699 & 100 & 2 & 0.1435 & $7.72 \mathrm{E}-3$ & $1.12 \mathrm{E}-2$ & $2.15 \mathrm{E}-1$ & $1.69 \mathrm{E}+1$ & $2.81 \mathrm{E}+0$ \\
\hline TZM6 & 700 & 500 & 2 & 0.1820 & $9.83 \mathrm{E}-3$ & & $3.57 \mathrm{E}-1$ & $3.57 \mathrm{E}+1$ & $2.79 \mathrm{E}+1$ \\
\hline TZM12 & 700 & 1000 & 2 & 0.1645 & $7.80 \mathrm{E}-3$ & & $3.30 \mathrm{E}-1$ & $2.62 \mathrm{E}+1$ & $4.93 \mathrm{E}+1$ \\
\hline TZM9 & 700 & 2500 & 2 & 0.1687 & $9.12 \mathrm{E}-3$ & & $3.36 \mathrm{E}-1$ & $3.13 \mathrm{E}+1$ & $8.67 \mathrm{E}+1$ \\
\hline TZM3 & 750 & 1000 & 1 & 0.2873 & $3.11 \mathrm{E}-2$ & $5.46 \mathrm{E}-2$ & $1.20 \mathrm{E}+0$ & $3.82 \mathrm{E}+2$ & $4.75 \mathrm{E}+2$ \\
\hline TZM2 & 800 & 1000 & 1 & 2.8435 & $3.05 \mathrm{E}-1$ & $3.85 \mathrm{E}-1$ & $7.80 \mathrm{E}-1$ & $2.42 \mathrm{E}+3$ & $3.79 \mathrm{E}+3$ \\
\hline
\end{tabular}

(a) The value reported for $400^{\circ} \mathrm{C}$ is a maximum as established by the detection limit from ICP-AES. 


\subsection{FEATURES OF OXIDIZED SPECIMENS.}

3.2.1 SPECIMEN APPEARANCE. The oxidized specimens of the TZM alloy were photographed at low magnification. Photographs in Figure 2 show specimens tested at various temperatures. Increasing amounts of residual oxide are apparent with increasing temperatures and times for up to $650^{\circ} \mathrm{C}$. Above $700^{\circ} \mathrm{C}$ the amount of residual oxide is notably less due to oxide evaporation. The samples exposed at 750 and $800^{\circ} \mathrm{C}$ have only a thin darker oxide layer. The oxide on the specimen exposed at $800^{\circ} \mathrm{C}$ shows evidence of having been molten. It flowed down the surfaces of the specimen and formed a glob at the bottom. Figure 3 shows photographs of specimens tested at $700^{\circ} \mathrm{C}$ under various flow conditions. Data in Table 2 show that there were comparable amounts of molybdenum metal oxidized for all flow conditions, however, significantly greater amounts were volatilized with the higher flow rates. This is reflected in the appearance of the specimens in Figure 3. The specimens with the lower flow rates have crystals developed on the surfaces. Volatilizing molybdenum trioxide species apparently were not swept away but instead re-deposited on preferentially oriented seed crystals located on the specimen surfaces. The specimens with higher flow rates had smoother surfaces and evidence of a darker underlying oxide showing that more of the oxide was volatilized and transported from the specimens in agreement with the ICP-AES measurements.

\section{Oxidized Specimens: Air Flow (1 liter/minute)}

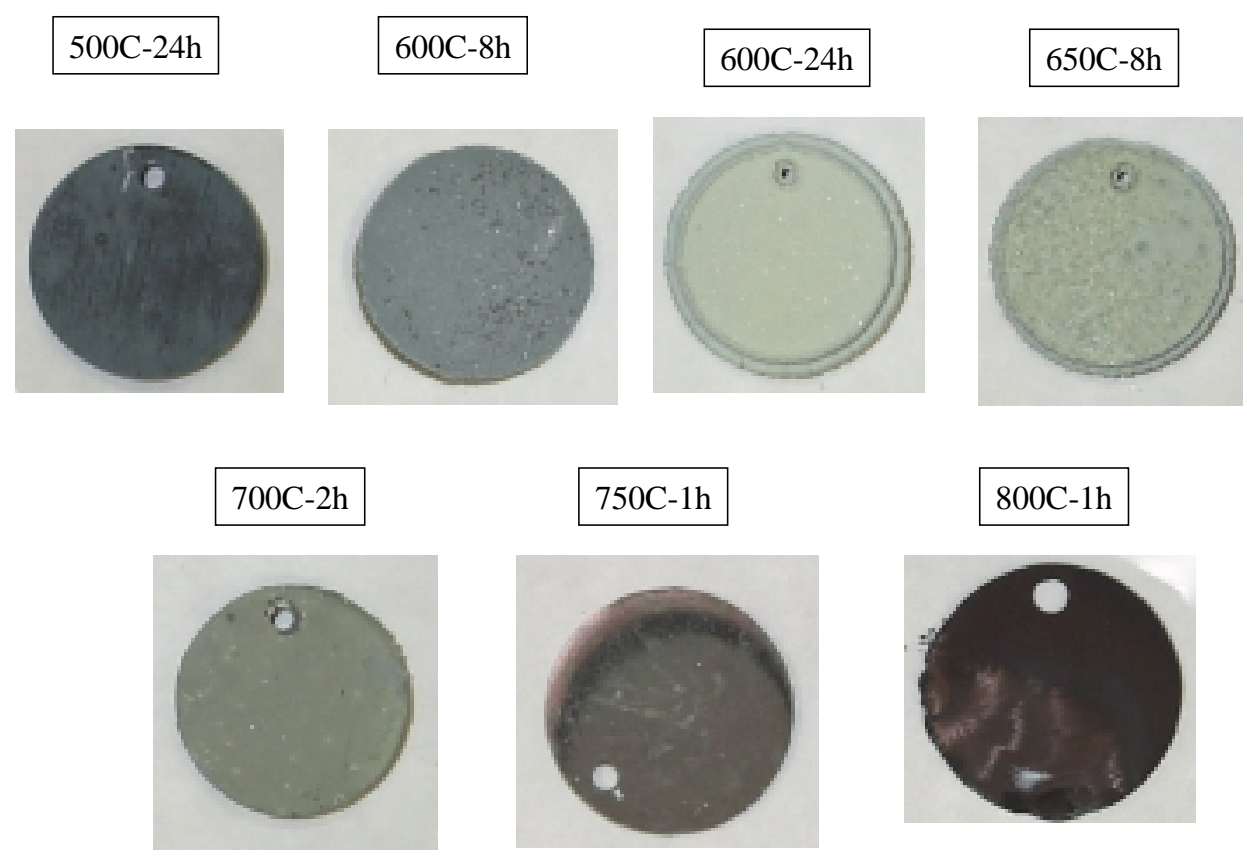

Figure 2. Specimens of TZM alloy oxidized at various temperatures and times in air. 


\section{Effect of Flow Rate on Specimens Oxidized at $700^{\circ} \mathrm{C}$}
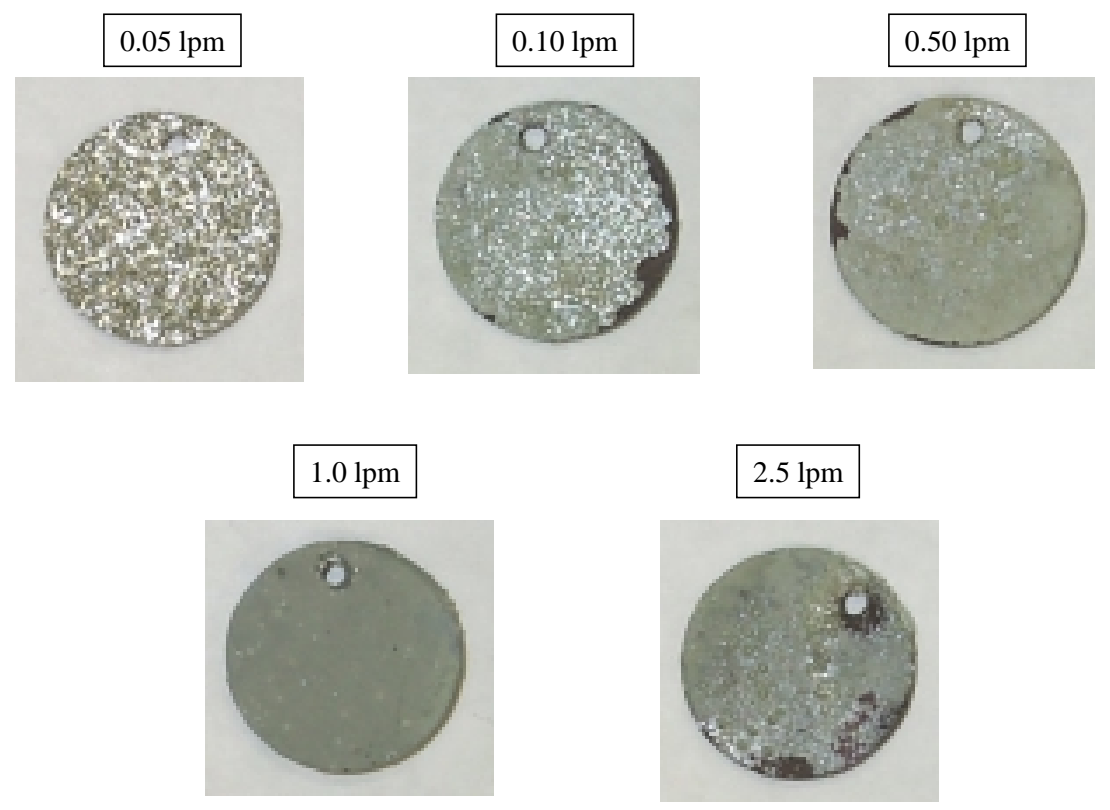

Figure 3. Specimens of TZM alloy tested in air at $700^{\circ} \mathrm{C}$ with different flow rates.

3.2.2 MICROSTRUCTURAL OBSERVATIONS OF OXIDIZED SPECIMENS. Oxides formed on specimens were examined with the aid of optical metallography (OM), SEM and XRD. Metallographic cross sections showed both thicknesses of residual oxide layers and profiles of oxide formations on the specimens. A specimen exposed for 24 hours at $500^{\circ} \mathrm{C}$ possessed a $0.02-\mathrm{mm}$ thick oxide layer with some irregularly distributed crystals extending to a height of $0.065 \mathrm{~mm}$. A SEM image of surface oxides formed under such conditions is shown in Figure 4. Thicker oxide scales with multiple layers were apparent for higher temperature tests. A dense oxide layer with intrusions into the metal matrix and cusps-like formations on the outer oxide layer is shown for the 24 -hour $600^{\circ} \mathrm{C}$ test in Figure 5. The outer regions of the oxide also show numerous cracks caused by the growth stresses in the oxide. This suggests that the surface area available for evaporation could be significantly higher than the initial geometric area of the specimen. However, the specimen tested for 8 hours at $600^{\circ} \mathrm{C}$ not showing such exaggerated oxide growth had a higher mass flux rate (see Table 2). This indicates that instead of the cracks within the oxide contributing to mobilization, the cusp-like formation may influence the flow pattern and reduce volatilization. The inner oxide layer and the extent of external oxide crystal growth depended upon the flow rate for $700^{\circ} \mathrm{C}$ tests. Figure 6 shows that the oxides existed primarily as externally protruding crystals on the specimens with a flow rate of $10 \mathrm{sccm}$. The specimen with a flow rate of $100 \mathrm{sccm}$ had a more continuous $0.06-\mathrm{mm}$ thick layer but still some external crystal growth (see Figure 7). Figure 8 shows only a 0.04-mm thick oxide layer with no evidence of external crystal growth for the specimen tested with a flow rate of $1000 \mathrm{sccm}$. This 
correlates with the higher mass flux shown for TZM12 in Table 2. The thickness of the residual oxide layer was significantly less for tests at $700^{\circ} \mathrm{C}$ and higher. OM and SEM in Figure 9 show that the oxide layer for the $750^{\circ} \mathrm{C}$ is about $0.013-\mathrm{mm}$ thick. OM provides evidence of crystal structure in the oxide layer while SEM provides better resolution of the porosity and layers within the oxide. A cross section of the very thin oxide layer (less than $0.01 \mathrm{~mm}$ ) and glob-like formation near the bottom of the specimen tested at $800^{\circ} \mathrm{C}$ is shown in Figure 10 . The thin residual oxide layers for the $750^{\circ} \mathrm{C}$ and $800^{\circ} \mathrm{C}$ tests agree with information in Table 2 showing that most of the oxide that formed on the specimens evaporated.

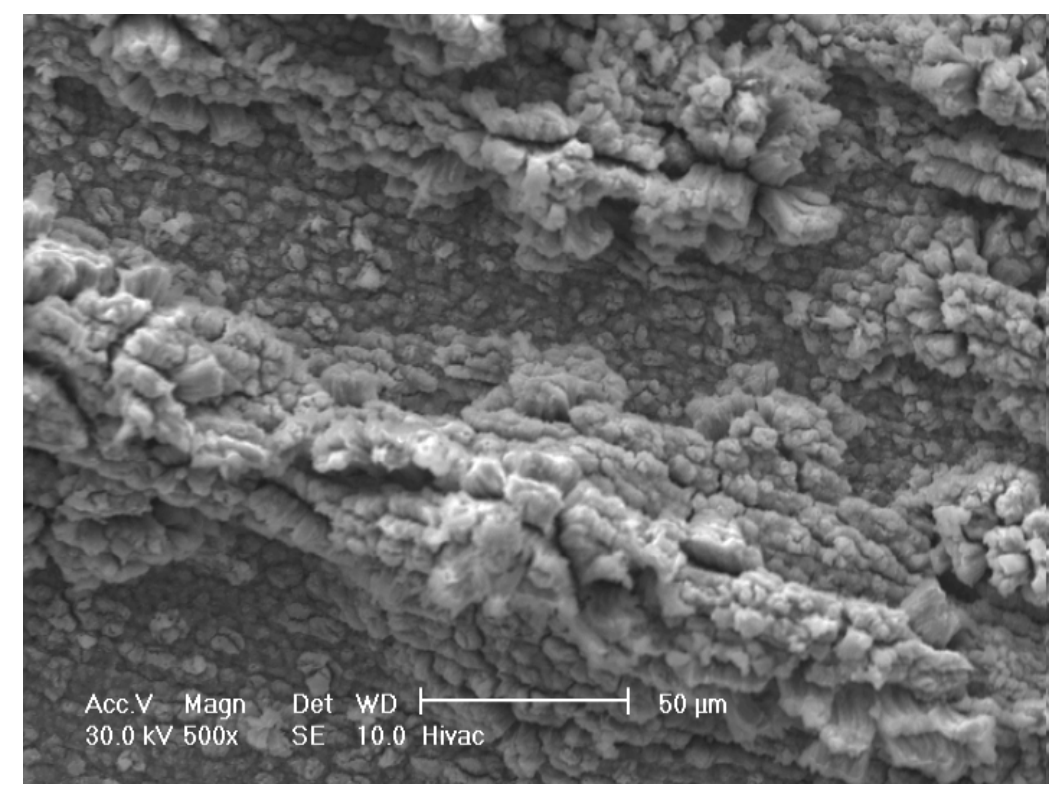

Figure 4. Oxides formed on the surface of specimen oxidized at $500^{\circ} \mathrm{C}$ for 24 hours. 


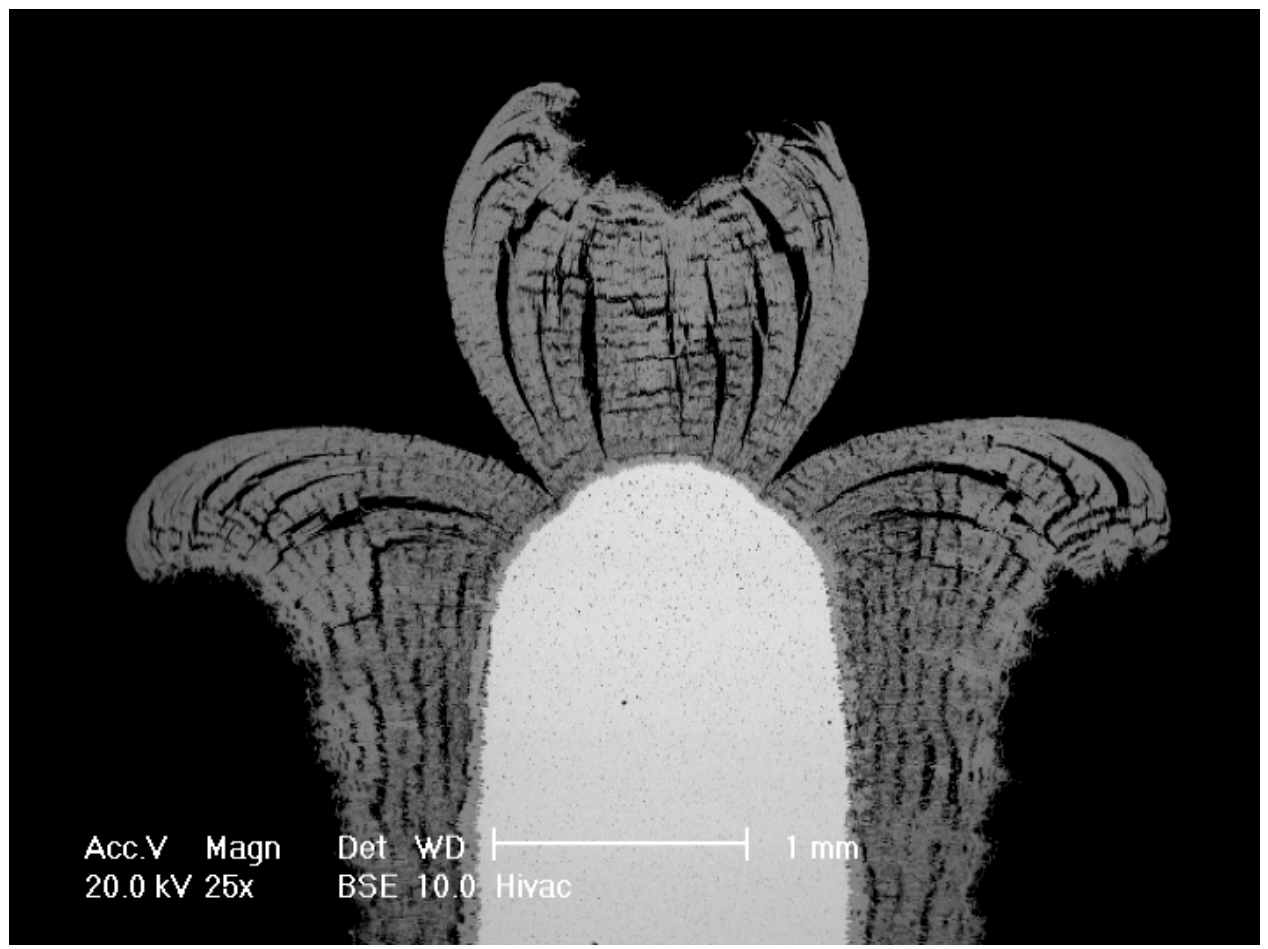

(a)

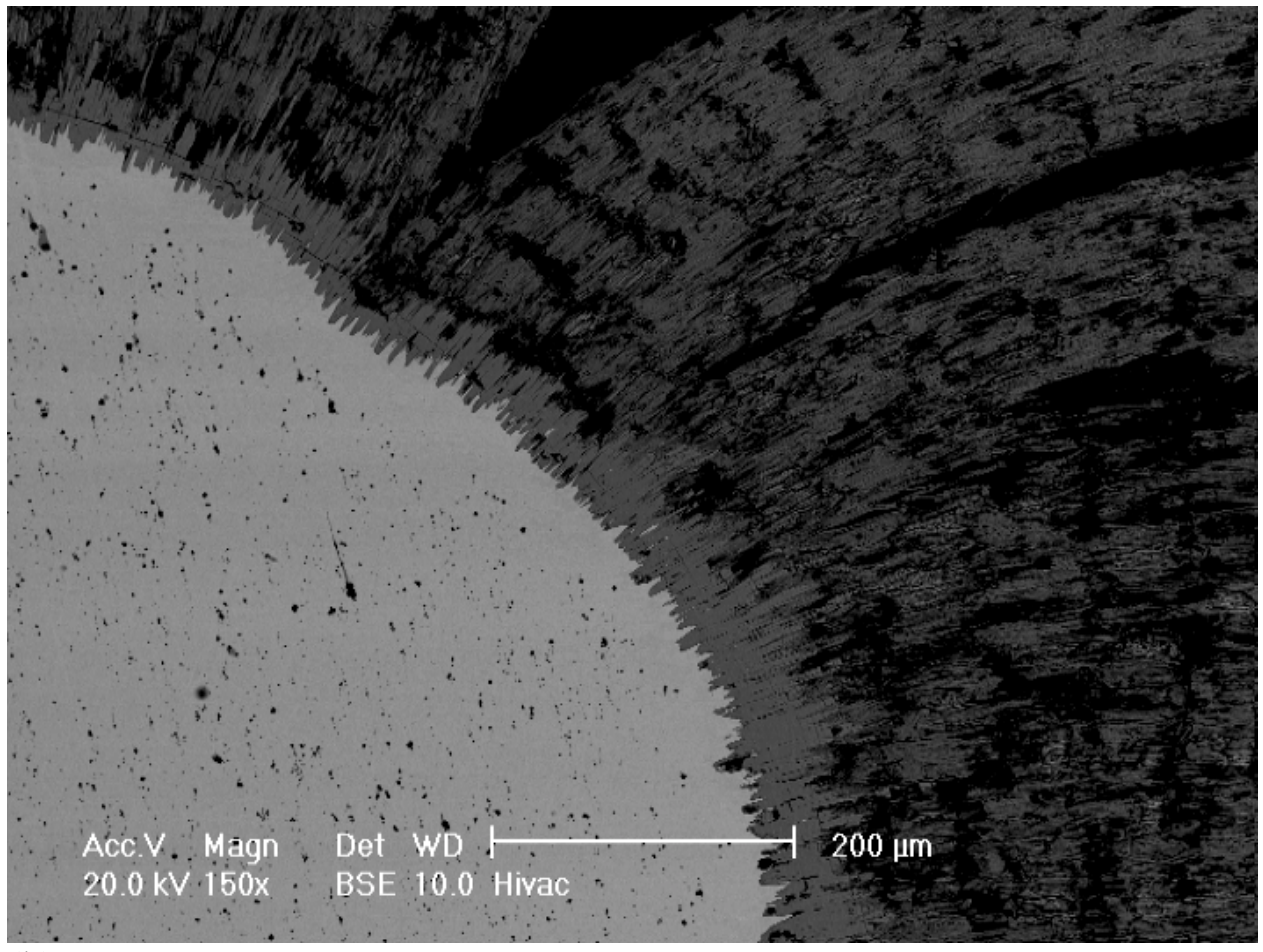

(b)

Figure 5. Cross section of specimen oxidized in air 24 hours at $600^{\circ} \mathrm{C}$. (a) Cusp-like oxide scale showing numerous cracks from growth stresses. (b) Layer at oxide to metal interface. 


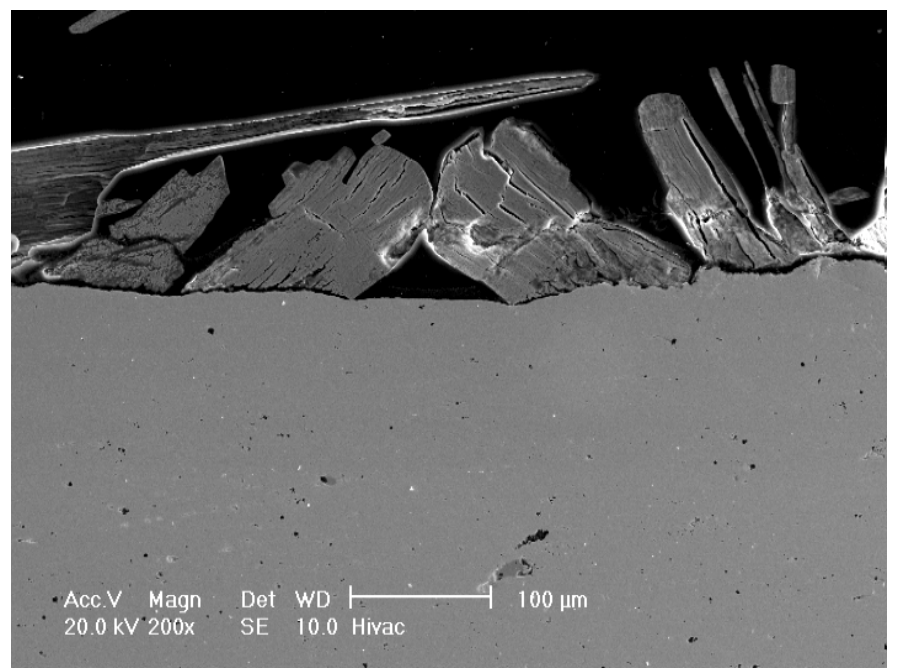

Figure 6. Oxide crystals on specimen oxidized at $700^{\circ} \mathrm{C}$ for two hours with $10 \mathrm{sccm}$ flow.

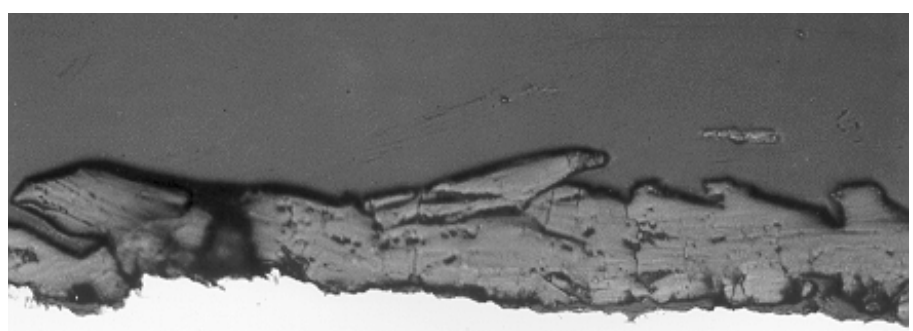

Figure 7. Oxide formed on specimen oxidized at $700^{\circ} \mathrm{C}$ for two hours with $100 \mathrm{sccm}$ flow.

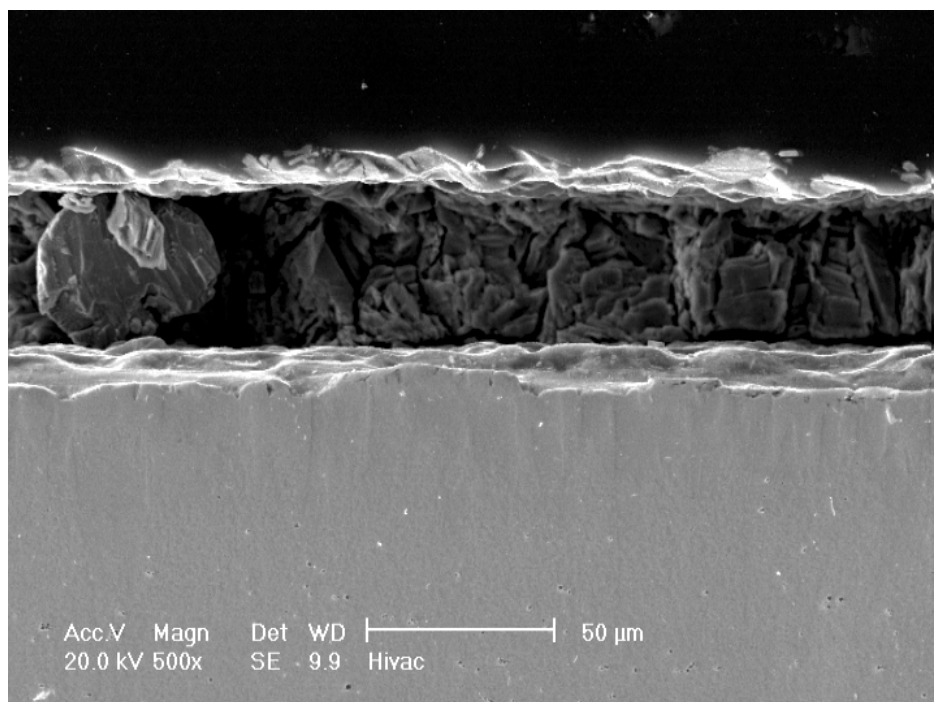

Figure 8. Oxide scale formed on specimen at $700^{\circ} \mathrm{C}$ after two hours with $1000 \mathrm{sccm}$ flow. 


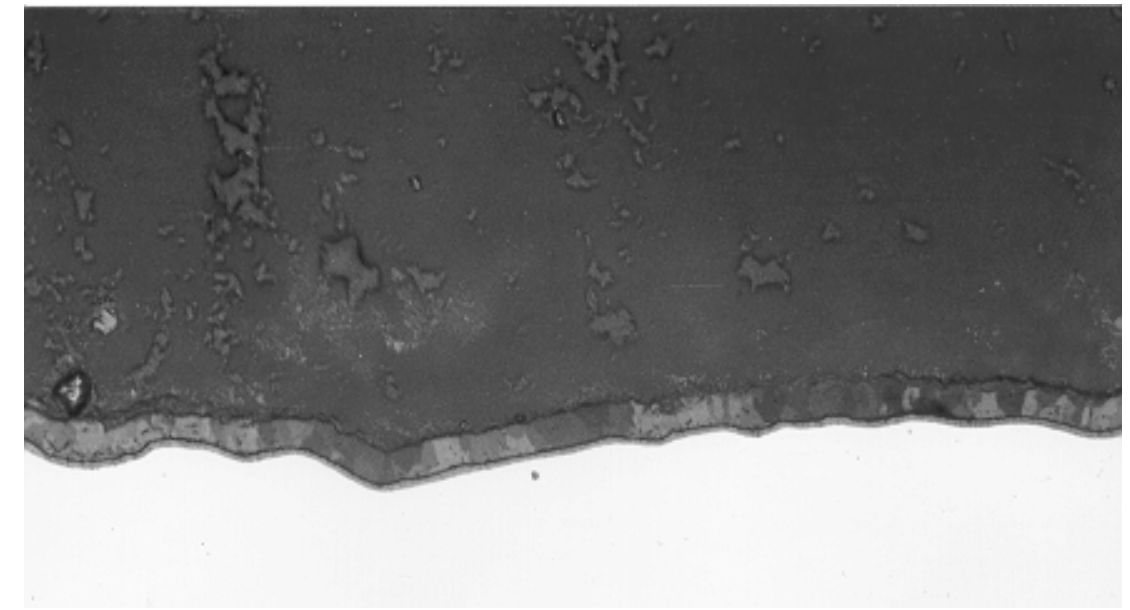

(a)

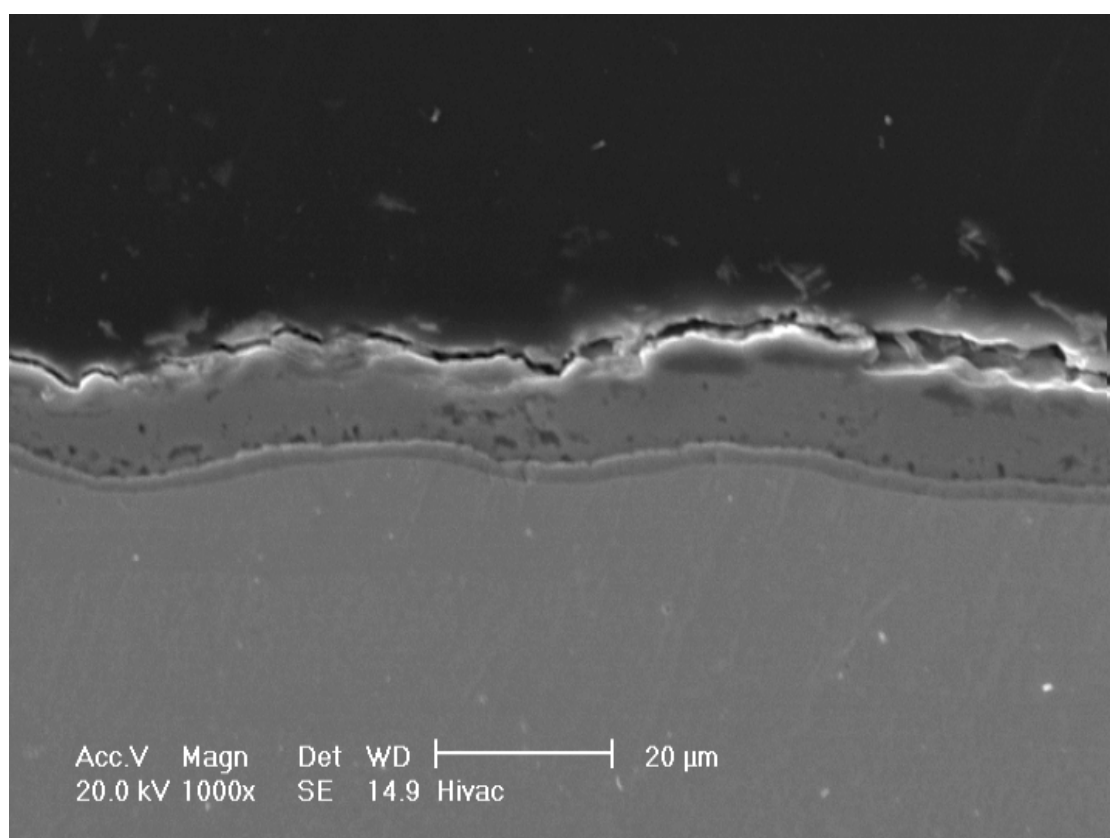

(b)

Figure 9. Residual oxide scale on specimen oxidized at $750^{\circ} \mathrm{C}$ for one hour with a flow rate of $1000 \mathrm{sccm}$. (a) optical micrograph (magnification: 400X). (b) SEM at 1000X. 


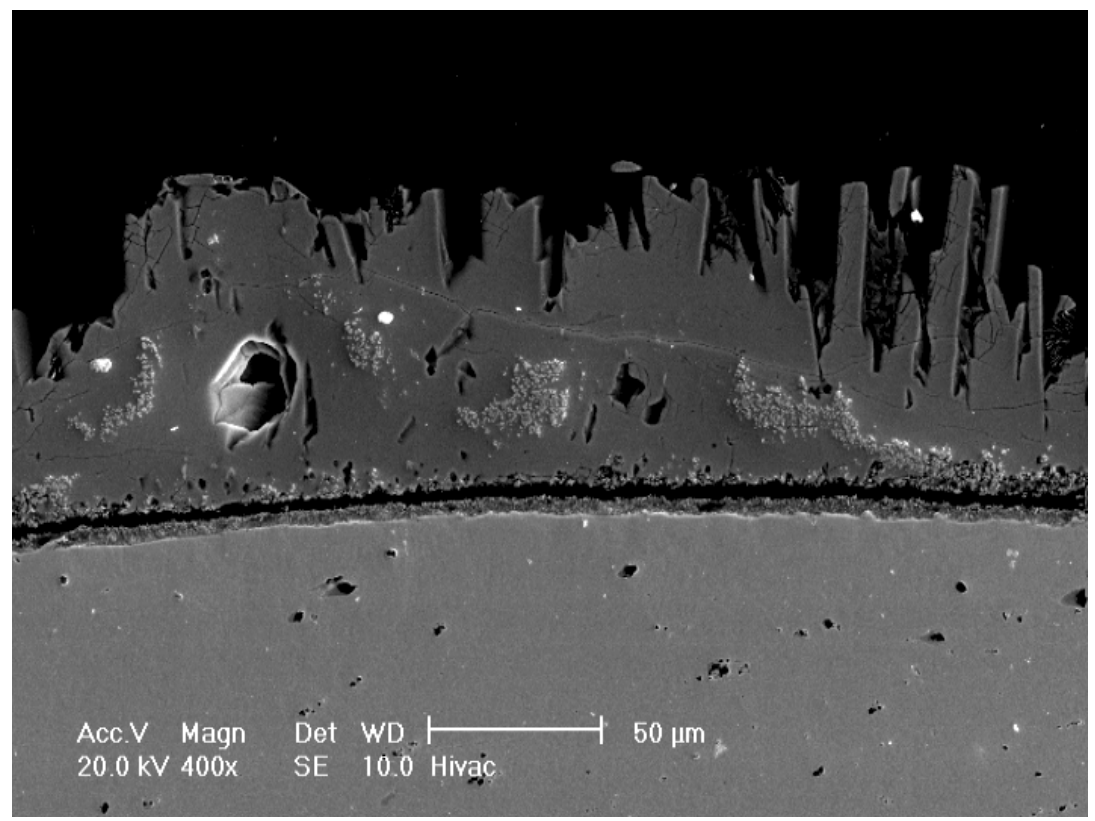

Figure 10. Thin oxide layer and glob-like formation from molten oxide on specimen oxidized at $800^{\circ} \mathrm{C}$ for one hour with $1000 \mathrm{sccm}$ flow rate.

3.2.3 PHASE AND CHEMISTRY DETERMINATIONS. Semi-quantitative analyses by energy dispersive x-ray spectroscopy (EDS) were obtained with the SEM from both cross sections and surfaces of oxidized specimens. In nearly all cases, i.e., including analyses near the oxide to metal interface and at outer regions of the oxide the molybdenum to oxygen ratio most closely indicated $\mathrm{MoO}_{2}$. In addition, many analyses within the base metal indicated high oxygen level, e.g. up to 25 at\%. The oxygen content in the base metal does not agree with phase diagram information showing no solubility of oxygen in molybdenum. XRD analyses from the surfaces of specimens tested at $550^{\circ} \mathrm{C}$ (TZM16) and $600^{\circ} \mathrm{C}$ (TZM7) indicated only $\mathrm{MoO}_{3}$ as shown by the spectrum in Figure 11. We could not detect any $\mathrm{MoO}_{2}$. Its presence, however, as a thin oxide layer at the oxide to metal interface as suggested by some authors cannot be discounted since XRD will not detect minor phases. The confirmation of $\mathrm{MoO}_{3}$ by XRD and oxygen indications from the base metal causes us to question the validity of the EDS analyses. High molybdenum concentrations produce an excitation peak, which is located very near the oxygen peak. Perhaps the EDS software cannot appropriately handle background subtractions or other analytical corrections associated with the excitation peak. 


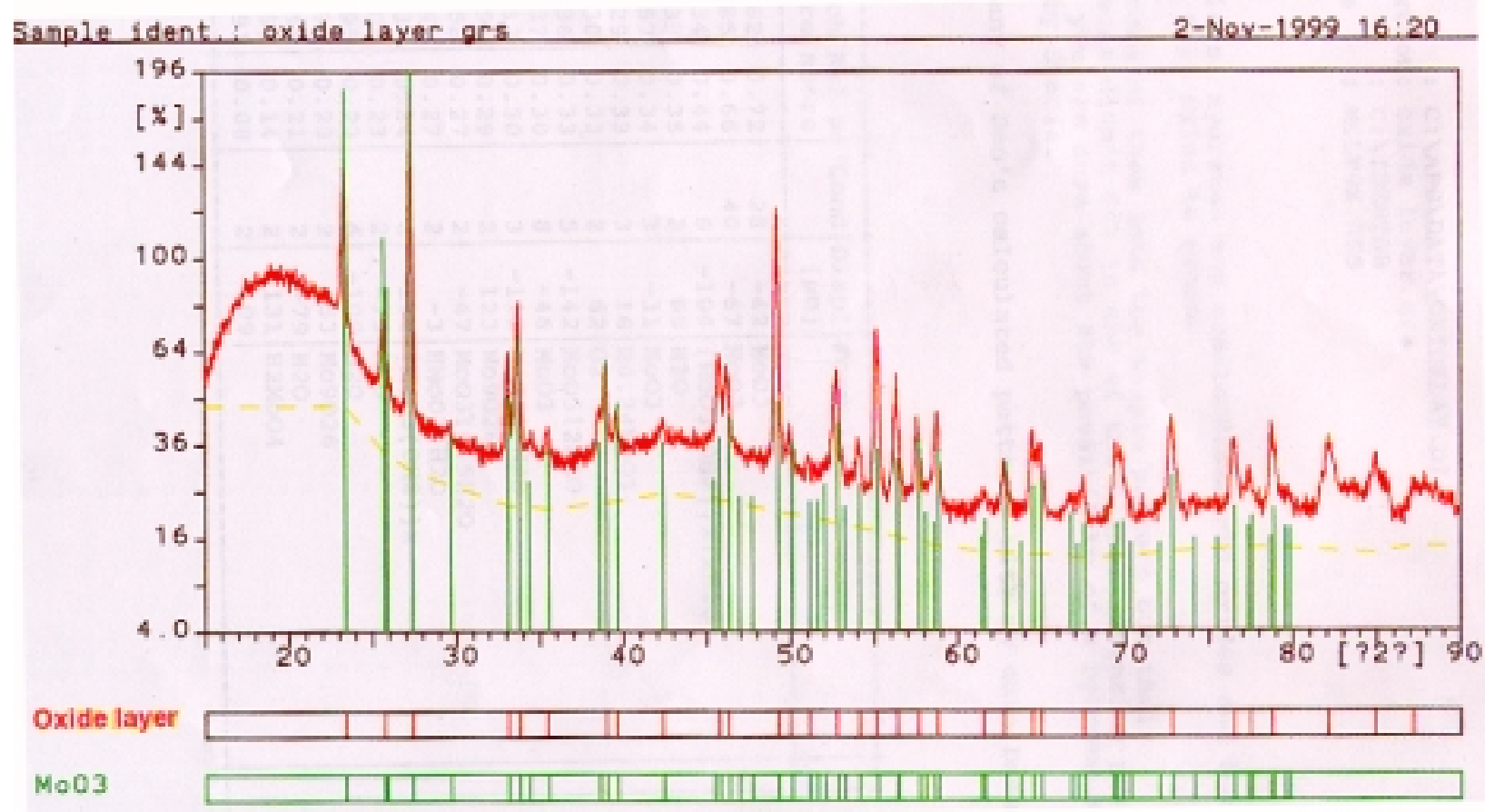

Figure 11. XRD spectrum from specimen oxidized at $600^{\circ} \mathrm{C}$ for 24 hours showing only the presence of $\mathrm{MoO}_{3}$.

\subsection{FEATURES OF RE-DEPOSITED OXIDE.}

The test components were examined after the test and the type, color and location of re-deposited oxide were recorded. Detailed records for each test are given in Appendix A. Photographs were taken of the collection tube for some of the tests. Some of these tests showed a start, or heavy concentration, of crystal growth at about 12 inches along the collection tube where temperature decreased to around 550 to $600^{\circ} \mathrm{C}$. This region corresponded to the highest concentration of redeposited molybdenum as determined by ICP-AES. Downstream from this region showing distinctive crystal growth there was often another type of deposit having either a smoky or sometime bluish hue. Sometimes a fairly heavy blue deposit collected at the front end of the quartz wool filter. Figure 12 shows the re-deposited oxides and molybdenum distribution for a test run at $700^{\circ} \mathrm{C}$ for two hours with a flow rate of $500 \mathrm{sccm}$. The SEM micrograph in Figure 12 shows that the product collected in the quartz wool consists of agglomerations of very small particles. Figure 13 shows an extremely heavy crystalline deposit for the $800^{\circ} \mathrm{C}$ tests. The deposit bridges and appears to nearly fill the collection tube at this location. Descriptions of deposits, molybdenum deposition profiles, and temperature profiles for all of the other tests are given in Appendices $\mathrm{A}$ and $\mathrm{C}$. 


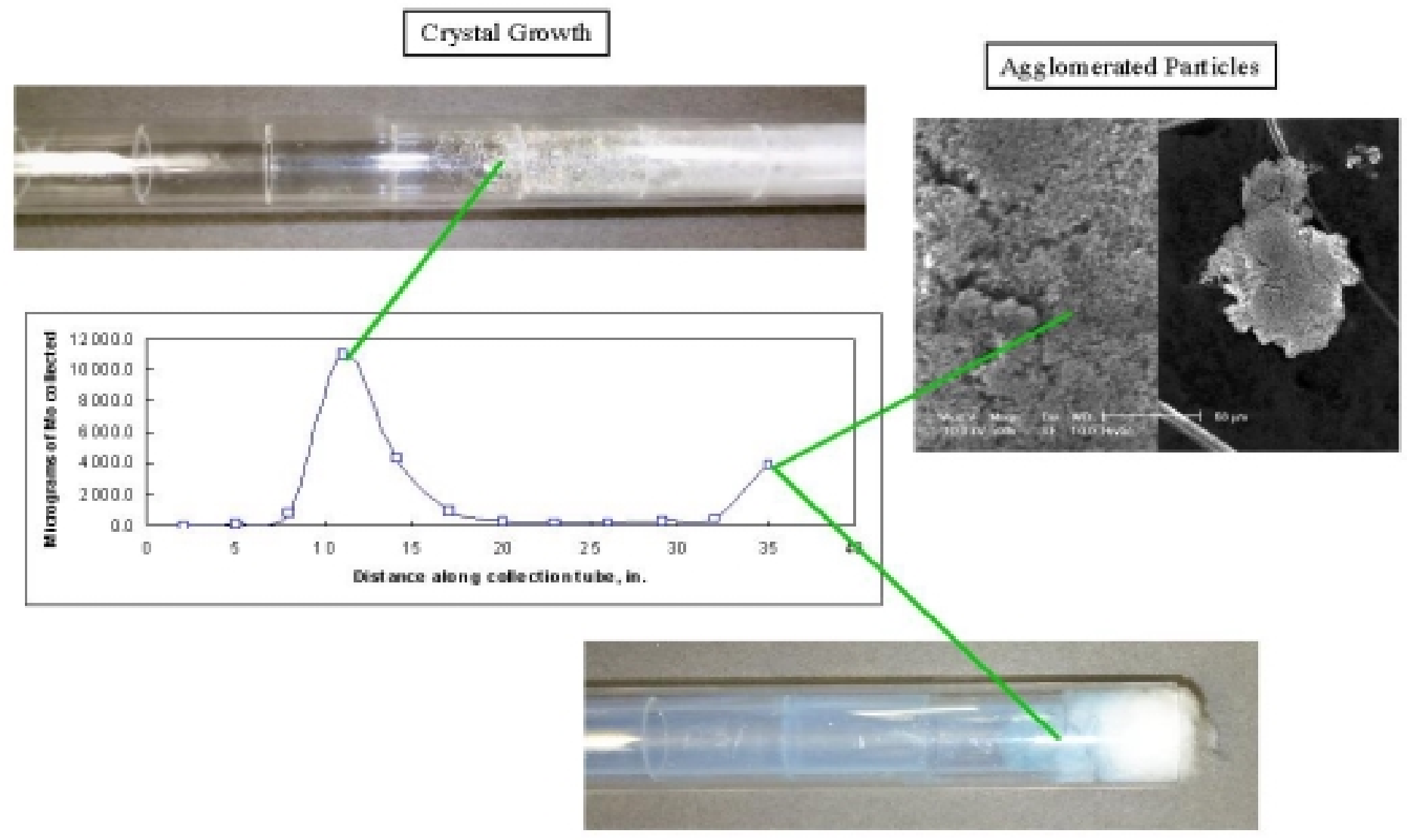

Figure 12. Oxide deposition products from specimen tested in air at $700^{\circ} \mathrm{C}$ for two hours with a flow rate of $500 \mathrm{sccm}$. 


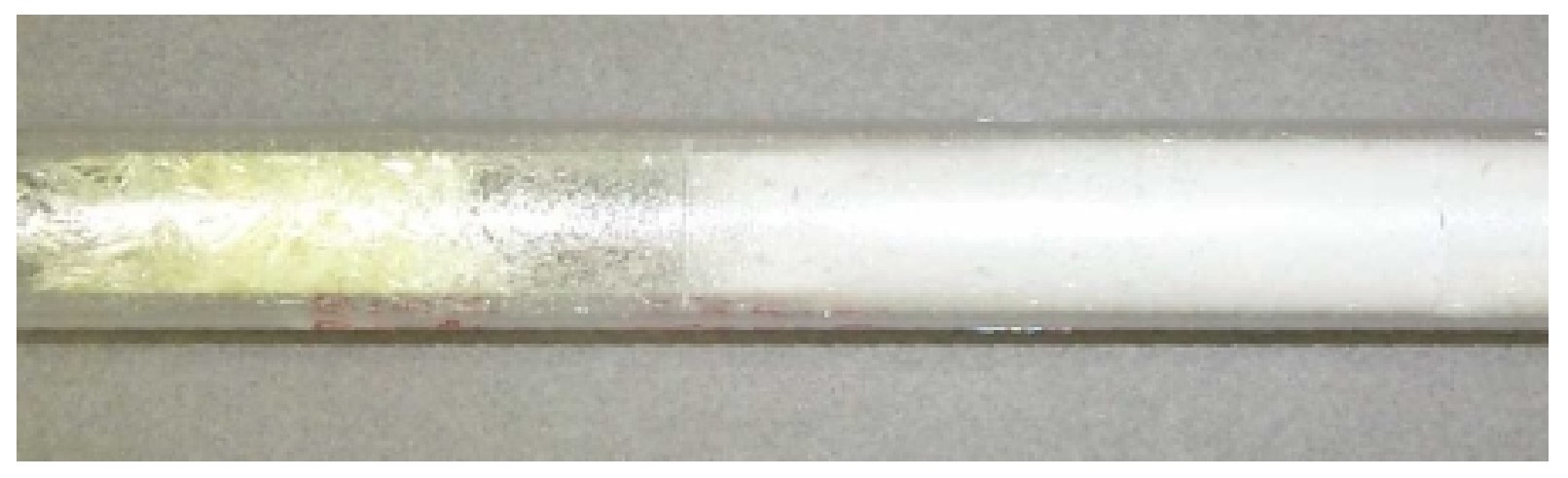

Figure 13. Yellow crystalline deposit and white smoky deposit formed in the collection tube for a test run at $800^{\circ} \mathrm{C}$ for one hour with a flow rate of $1000 \mathrm{sccm}$.

\subsection{DISCUSSION}

4.1 OXIDATION RATE OF TZM ALLOY. We have plotted the recession rates, fractions of "reacted" metal volatilized, and mass flux rates from Table 2 with respect to reciprocal temperature. The plot for the recession rates is shown in Figure 14. The plot shows a good correlation between rates obtained by the $(\Delta \mathrm{m}+\mathrm{ICP}-\mathrm{AES})$ and metallographic methods. The plot shows a maximum at $650^{\circ} \mathrm{C}$ (the rate at $650^{\circ} \mathrm{C}$ is 2 to 3 times higher than at 600 and $700^{\circ} \mathrm{C}$ ), and then sharply increasing rates from 700 to $800^{\circ} \mathrm{C}$. This trend in oxidation rate is very similar to those observed for the other refractory metals of niobium[2] and tantalum[3]. The irregularities are attributed to various non-stoichiometric phases other than $\mathrm{Nb}_{2} \mathrm{O}_{5}$ or $\mathrm{Ta}_{2} \mathrm{O}_{5}$. Speiser and St. Pierre 6] reported that they sometimes observed a thin $\mathrm{MoO}_{2}$ layer, or an external $\mathrm{MoO}_{3}$ layer with a thin sub-layer of $\mathrm{MoO}_{2}$ or other oxides during the oxidation of molybdenum in air between 450 to $770^{\circ} \mathrm{C}$. The other oxides were reported as being non-stoichiometric, i.e., $\mathrm{MoOz}$ with " $\mathrm{z}$ " varying between 2 and 3 . The similar characteristics of the refractory metals and the observations above suggest the maximum at $650^{\circ} \mathrm{C}$ in Figure 14 is real and likely caused by different types of oxide. Although we have little data to show kinetic behavior, the two tests at $600^{\circ} \mathrm{C}$ indicate linear or even slightly accelerating behavior (Table 2).

4.2 VOLATILIZATION PROCESS FROM OXIDIZED TZM ALLOY. The plot of calculated fraction of "oxidized" molybdenum volatilized in Figure 15 show a marked increase above $650^{\circ} \mathrm{C}$. Generally 20 to 33 percent of the oxide that formed volatilized at $700^{\circ} \mathrm{C}$ except for the tests with the lowest flow rates of 10 and $50 \mathrm{sccm}$. Although all $700^{\circ} \mathrm{C}$ tests formed similar amounts of oxides (Table 2), only about one-tenth as much of the oxide volatilized at the lower flow rates. Our model subsequently presented shows this is the result of partial saturation of the gas phase with the $\mathrm{MoO}_{3}$, effectively reducing the volatilization at low flow rates. Most of the oxide was volatilized at 750 and $800^{\circ} \mathrm{C}$. This corresponds with our metallographic observations of only a thin ( 3 to $10 \mu \mathrm{m}$ ) oxide on these specimens. The high rate of volatilization is apparently linked to the increase in oxidation rate for these two temperatures as shown in Figure 14. Our data agree with that of Gulbransen, et al.[1], where all of the oxygen reacted at $800^{\circ} \mathrm{C}$ in 76 torr oxygen and formed volatile oxides. The specimen tested at $800^{\circ} \mathrm{C}$ showed evidence of a molten layer. The sides were smooth and parallel indicative of molten oxide flowing down the specimen. A thicker region at the bottom of the specimen contained 


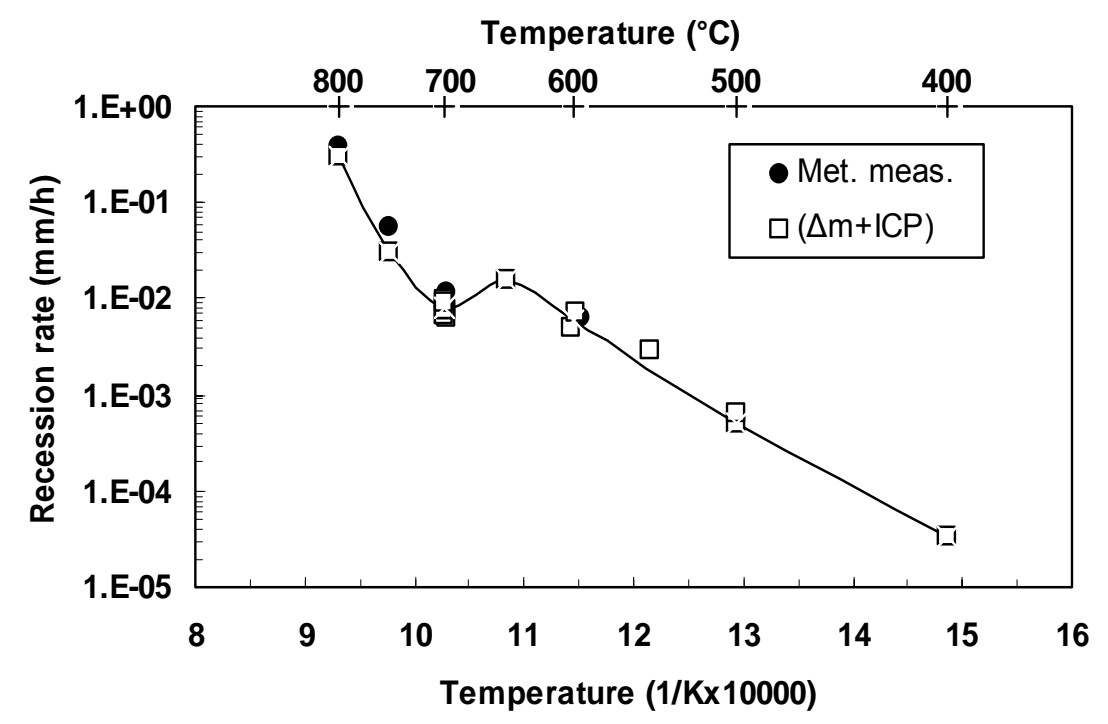

Figure 14. Oxidation rates of TZM alloy as shown the rate of metal reacted $(\mathrm{mm} / \mathrm{h})$.

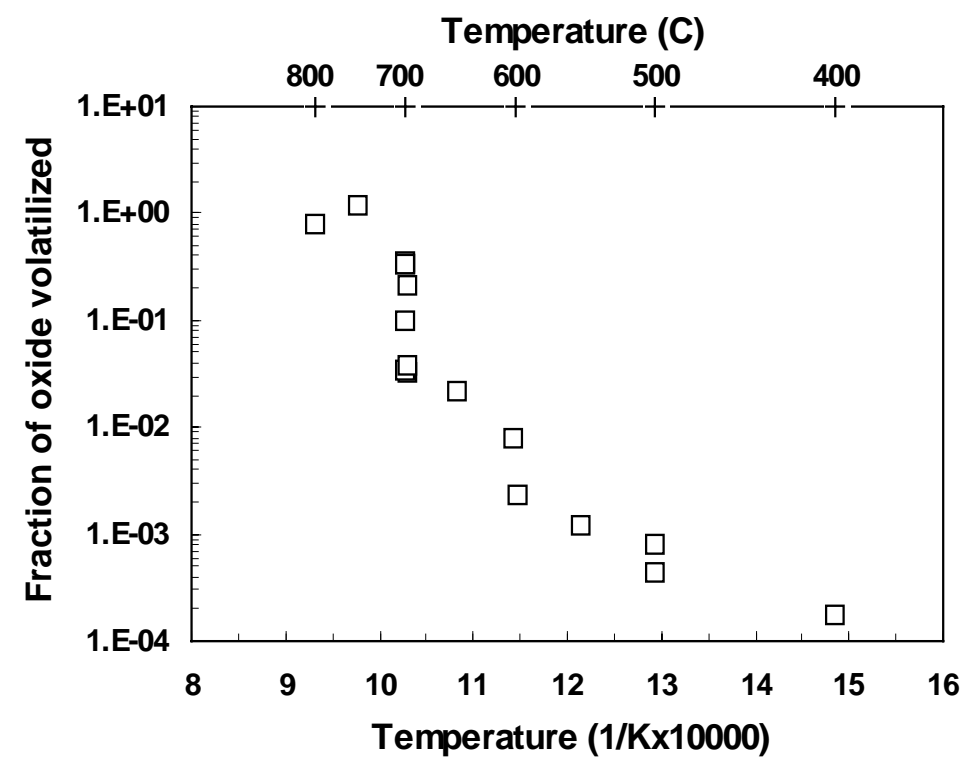

Figure 15. The fraction the $\mathrm{MoO}_{3}$ volatilized plotted with respect to temperature.

some oxides as revealed in the metallographic cross section. This agrees with temperatures reported for the melting points of $\mathrm{MoO}_{3}\left(795^{\circ} \mathrm{C}\right)$ and a $\mathrm{MoO}_{3}-\mathrm{MoO}_{2}$ eutectic $\left(778^{\circ} \mathrm{C}\right)[6]$. The higher vapor pressure above the melting point would increase volatilization rates, which in turn would increase oxidation rates by removing the oxide barrier.

Insight into the mechanisms governing oxidation and volatilization processes of molybdenum metal at temperatures from 827 to $1127^{\circ} \mathrm{C}$ is provided by Olander and Schofill[4]. They believe that very thin coatings of $\mathrm{MoO}_{2}$ exist even at high temperatures where rapid evaporation occurs by the overall reaction: $\mathrm{Mo}(\mathrm{s})+3 / 2 \mathrm{O}_{2}(\mathrm{~g})=1 / \mathrm{m}\left(\mathrm{MoO}_{3}\right)_{\mathrm{m}}(\mathrm{g})$. Although the influence of oxygen adsorption on the oxidation behavior of refractory metals has been widely reported, 
Olander, et al.44 relate the dissociative adsorption of oxygen as the controlling mechanism via the reaction: $\mathrm{O}(\mathrm{ads})+\mathrm{MoO}_{2} \rightarrow \mathrm{MoO}_{3}$ (ads). The available active sites facilitating the adsorption of oxygen in turn depend upon the anion vacancy concentration in the n-type semiconductor structure of molybdenum dioxide. The above theory may help explain some of our data at lower temperatures. The volatilization rate for the 24 -h test of $0.162 \mathrm{~g} /\left(\mathrm{m}^{2}-\mathrm{h}\right)$ was less than the rate of $0.397 \mathrm{~g} /\left(\mathrm{m}^{2}-\mathrm{h}\right)$ for the 8 -h test at $600^{\circ} \mathrm{C}$. Perhaps the stoichiometry of the oxide changed as the oxide scale grew with time and influenced the number of active sites. It is also possible that as the oxide thickened the flow pattern around the specimen changed decreasing the volatilization rate.

4.3 MODEL OF VOLATILIZATION RATES. We used a vaporization mass transfer model to predict the mobilization of molybdenum from the specimens tested in air. The model based on the experimental geometry, thermal hydraulic conditions and vapor pressures of the volatile trioxides, $\left(\mathrm{MoO}_{3}\right)_{\mathrm{m}}$, and hydroxide, $\mathrm{MoO}_{2}(\mathrm{OH})_{2}$, was used to predict the mobilization mass flux of molybdenum, $\mathrm{J}$, as expressed by Eq.(2).

$$
\mathrm{J}=\mathrm{k}\left(\mathrm{p}^{\mathrm{Mo}}-\mathrm{p}^{\text {bulk }}\right) / \mathrm{RT}
$$

where

$\mathrm{k}=$ mass transfer coefficient $(\mathrm{m} / \mathrm{s})$,

$\mathrm{p}^{\mathrm{Mo}}=$ partial pressure of volatile molybdenum species at surface of the specimen,

$\mathrm{p}^{\text {bulk }}=$ partial pressure of volatile molybdenum species in bulk steam flow.

Since the flow in the experiment is laminar, the mass transfer coefficient is given by [8]:

$$
\mathrm{k}=1.86[\operatorname{Re} \operatorname{Sc}(1 / \mathrm{d})]^{1 / 3} \mathrm{D} / \mathrm{d}
$$

$\mathrm{D}$ is the diffusion coefficient of the volatile molybdenum species in air based on classic Chapman-Eskong theory [8] and Re is the Reynolds number, Sc is the Schmidt number, and 1 and $d$ are the length and diameter of the furnace. Surface to bulk pressures of the volatile molybdenum species are corrected for the partial saturation of the species in the bulk flow by Eq. (4), where $Q$ is the volumetric flow rate of air $\left(\mathrm{m}^{3} / \mathrm{s}\right)$.

$$
\left(\mathrm{p}^{\text {bulk }} / \mathrm{p}^{\mathrm{Mo}}\right)=[1-\exp (-\mathrm{hA} / \mathrm{Q})]
$$

The partial pressure of $\left(\mathrm{MoO}_{3}\right)_{\mathrm{m}}$ is determined as an effective value for the various polymeric forms of $\left(\mathrm{MoO}_{3}\right)$ existing at different temperatures over pure solid or molten $\mathrm{MoO}_{3}$. Vapor pressures for the various polymer species were obtained from the HSC thermochemical computer code[ [9]. Correlations [10] for the effective average polymer number $(\mathrm{m})$ in $\left(\mathrm{MoO}_{3}\right)_{\mathrm{m}}$ were also determined. The primary species within our temperatures of interest are $\left(\mathrm{MoO}_{3}\right)_{3},\left(\mathrm{MoO}_{3}\right)_{4}$, and $\left(\mathrm{MoO}_{3}\right)_{5}$. Average polymer numbers above solid $\left(\mathrm{MoO}_{3}\right)$ are given by Eq. (5).

$$
\mathrm{m}=6.785-0.013193 \mathrm{~T}+1.432 \times 10^{-5} \mathrm{~T}^{2}-4.4235 \times 10^{-9} \mathrm{~T}^{3}
$$

The total vapor pressures of these average effective polymers over the solid phase up to the melting point as derived from the HSC thermochemical code are shown by Eq. (6).

$$
\log _{10} \mathrm{P}(\text { Torr })=8,599.81 / \mathrm{T}-186.495+63.1654 \log _{10} \mathrm{~T}-0.0078447 \mathrm{~T}-4,154,834 / \mathrm{T}^{2}
$$


Vapor pressures of the hydroxide formed by the reaction: $\mathrm{MoO}_{3(\mathrm{~s})}+\mathrm{H}_{2} \mathrm{O}_{(\mathrm{g})}=\mathrm{MoO}_{2}(\mathrm{OH})_{2(\mathrm{~g})}$, have been experimentally determined by Speiser and St. Pierre.6] They reported an equilibrium constant, $\mathrm{K}_{\mathrm{m}}$, for the reaction as expressed by $\mathrm{K}_{\mathrm{m}}=\mathrm{P}_{\text {hydroxide }} / \mathrm{P}_{\text {water }}$, to be given by Eq. (7).

$$
\log \mathrm{K}_{\mathrm{m}}=-7731 / \mathrm{T}+5.45 \text { (for } \mathrm{T}=873 \text { to } 963 \mathrm{~K} \text { ) }
$$

We obtained vapor pressures for the hydroxide species by using the relationship for $\mathrm{K}_{\mathrm{m}}$, the saturation pressure for water vapor in ambient temperature air of 17.55 Torr (2340 Pa), and the relative humidity. We used a parametric analysis to show vapor pressures of the hydroxide species at various relative humidities. The humidity at the INEEL is typically around 40 percent. Although we dried the air prior to introduction into the test system we postulate that there was some backflow and/or leakage of ambient air into the test system. We show comparisons of the vapor pressures of $\left(\mathrm{MoO}_{3}\right)_{\mathrm{m}}$ in dry air and $\mathrm{MoO}_{2}(\mathrm{OH})_{2(\mathrm{~g})}$ in environments with the various relative humidities, including a postulated test condition with a ten percent ingress, in Figure 16. The plots show that the vapor pressure of $\left(\mathrm{MoO}_{3}\right)_{\mathrm{m}}$ in air and $\mathrm{MoO}_{2}(\mathrm{OH})_{2(\mathrm{~g})}$ in the postulated experimental condition are about equivalent at $550^{\circ} \mathrm{C}$. In higher relative humidities, e.g., 80 to 100 percent, the temperature at which the vapor pressures of the two different species become equivalent would increase to about $650^{\circ} \mathrm{C}$.

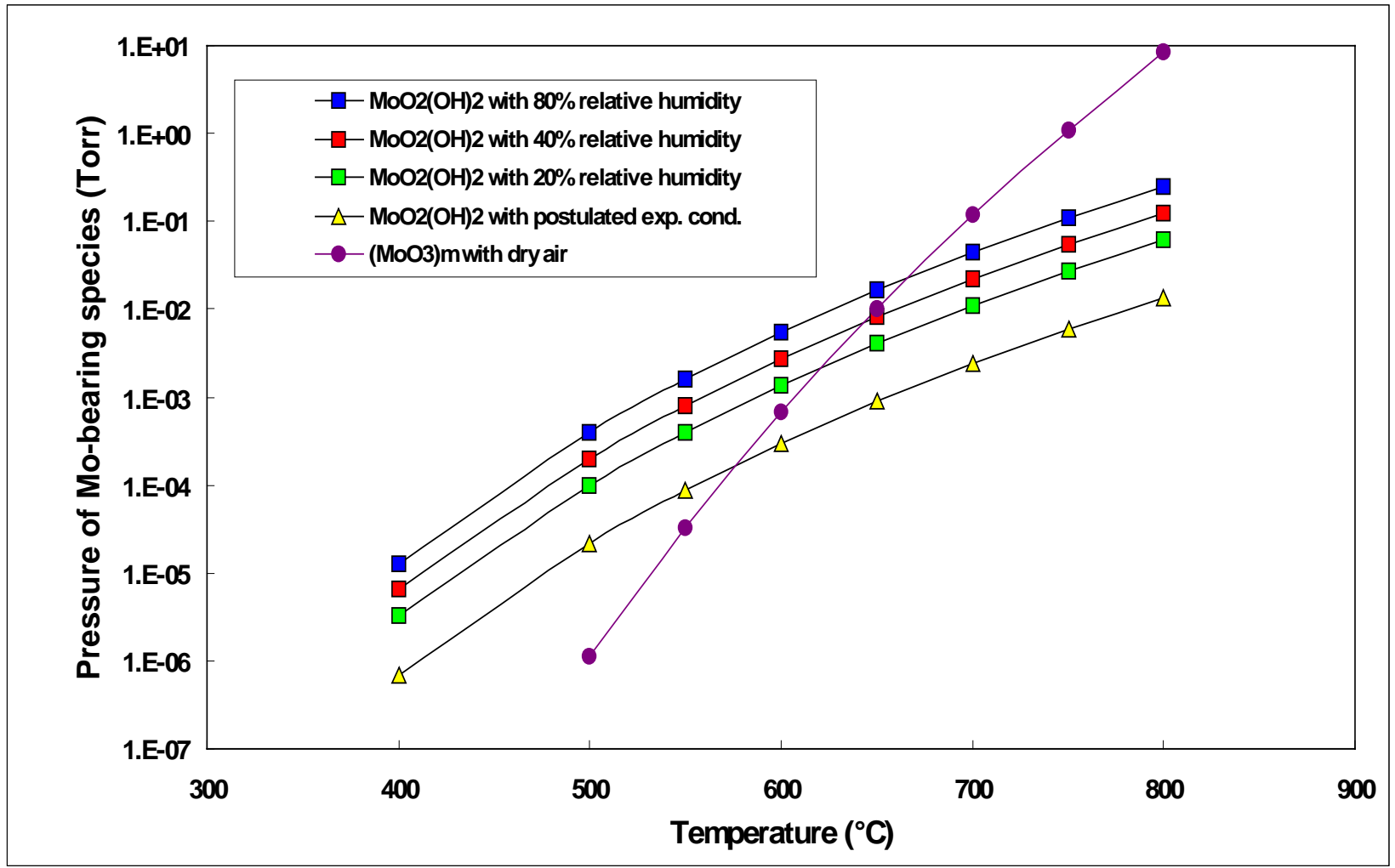

Figure 16. Vapor pressures of molybdenum trioxide and hydroxide species at various relative humidities and temperatures. 
We calculated contributions to the molybdenum mass flux from both the trioxide and hydroxide species using Eq. (2) through Eq. (7). Comparisons of predicted total mass flux of molybdenum with experimental measurements for the various times, temperatures, and flow rates are given in Table 2. The predictions for tests with a flow rate of one liter per minute are plotted along with the experimental data in Figure 17. The calculations show that below $550^{\circ} \mathrm{C}$ contributions from $\mathrm{MoO}_{2}(\mathrm{OH})_{2(\mathrm{~g})}$ dominate the volatilization process, whereas $\left(\mathrm{MoO}_{3}\right)_{\mathrm{m}}$ is the major contributor above this temperature. The model incorporating both species agrees quite well with experimentally derived mass flux measurements over the entire temperature range. Simnad and Spilners [5] showed a very similar trend for molybdenum metal oxidized between 500 and $770^{\circ} \mathrm{C}$ including an inflection in volatilization rate at $600^{\circ} \mathrm{C}$. They reported activation energies of $53.0 \mathrm{kcal} / \mathrm{mole}$ and $89.6 \mathrm{kcal} / \mathrm{mole}$ below and above $650^{\circ} \mathrm{C}$, respectively. We obtained activation energies of $41.4 \mathrm{kcal} / \mathrm{mole}$ between 400 and $500^{\circ} \mathrm{C}$ and $85.3 \mathrm{kcal} / \mathrm{mole}$ between 600 and $800^{\circ} \mathrm{C}$, respectively. We believe this supports the proposal that the hydroxide and trioxide species, respectively, are the active mechanisms in the two different temperature regions.

The trend of lower mass flux with lower flow rates at $700^{\circ} \mathrm{C}$ (shown in Table 2) is supported by our predictions using Eq. (3). The measured values, however, are still somewhat higher than predicted values for the lowest flow rates. Protruding crystals were observed growing from specimens tested in the low flow rates as evident in Figure 3 and Figure 6. We would expect environments with higher partial saturation to be more conducive to grow such crystals from preferential sites. Some of these crystals were quite needle, or ribbon-like, and would easily break off. In fact, ribbon and needle-like crystals were observed in the reaction tubes for $700^{\circ} \mathrm{C}$ tests with 10 and $50 \mathrm{sccm}$ flow rates and molybdenum measurements were higher compared to the other components (see Appendices A and C). This supports the suggestion that the high measurements for mobilized material compared to predicted values result from spalled crystals.

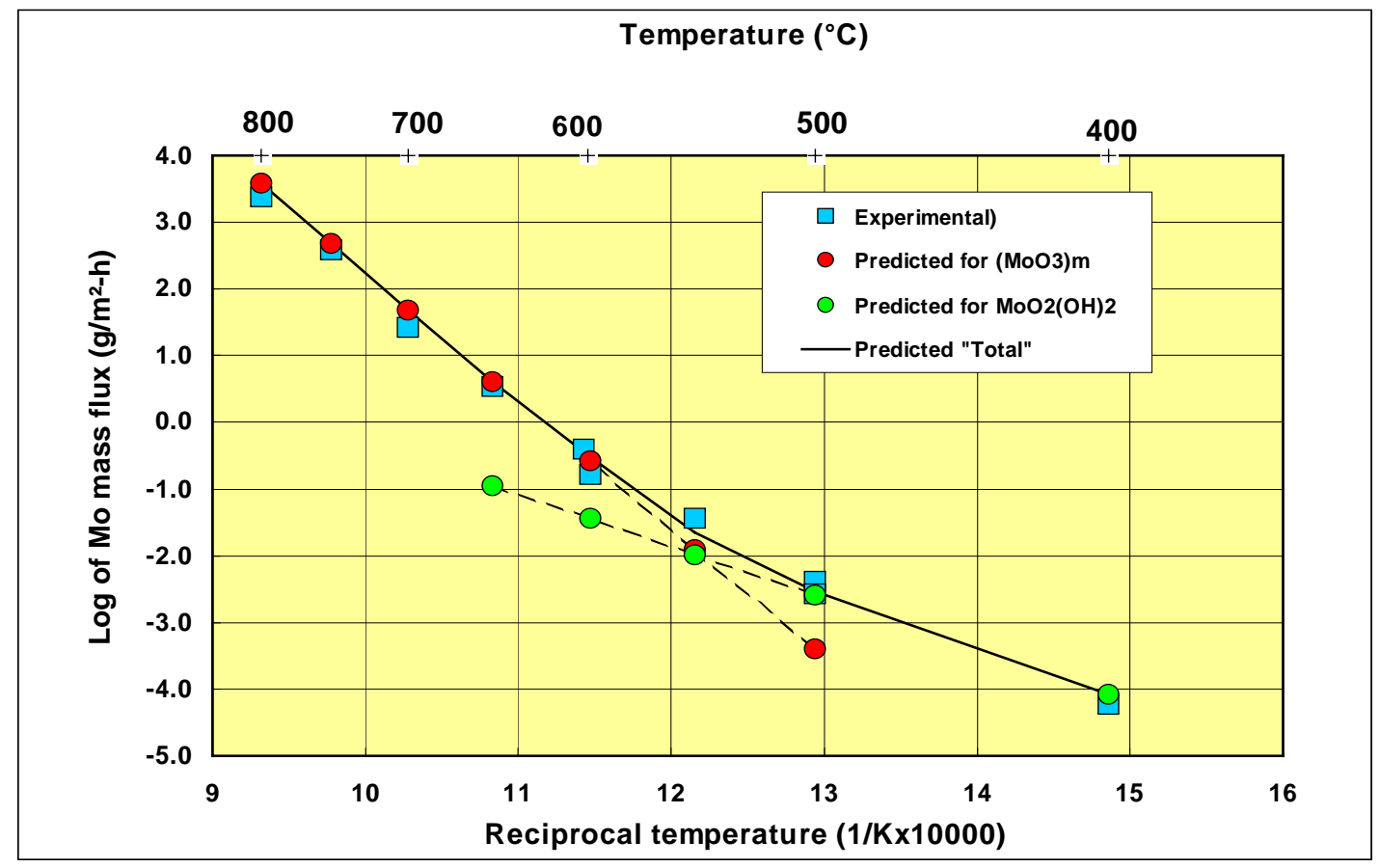

Figure 17. Mass flux of molybdenum showing experimental and predictions from the $\left(\mathrm{MoO}_{3}\right)_{\mathrm{m}}$ and $\mathrm{MoO}_{2}(\mathrm{OH})_{2(\mathrm{~g})}$ vapor species at various temperatures. 


\subsection{MODEL FOR RE-DEPOSITION OF MOBILIZED MOLYBDENUM.}

In this section, we present a simple condensation model that predicts the condensation profiles in the downstream components in the experiments. The $\left(\mathrm{MoO}_{3}\right)_{\mathrm{m}}$ vapors are assumed to be the primary species vaporized from the sample particularly at $600^{\circ} \mathrm{C}$ and higher as shown by the preceding section. For a given flow rate in the experiment, a concentration of $\left(\mathrm{MoO}_{3}\right)_{\mathrm{m}}$ in the gas phase is established by Eq. (8):

$$
\mathrm{C}_{\mathrm{gas}}=\left(\Gamma^{*} \mathrm{~A}\right) / \mathrm{Q}
$$

where,

$\mathrm{C}_{\text {gas }}=$ concentration of $\left(\mathrm{MoO}_{3}\right)_{\mathrm{m}}$ in gas $\left(\mathrm{kg} / \mathrm{m}^{3}\right)$,

$\Gamma \quad=$ measured mass flux from surface $\left(\mathrm{kg} / \mathrm{m}^{2}-\mathrm{s}\right)$,

A $\quad=$ initial surface area of sample $\left(\mathrm{m}^{2}\right)$, and

$\mathrm{Q}=$ volumetric flow rate of air $\left(\mathrm{m}^{3} / \mathrm{s}\right)$.

As a packet of gas travels down the tube, it cools and the $\left(\mathrm{MoO}_{3}\right)_{\mathrm{m}}$ becomes supersaturated. The saturation ratio expressed by Eq. (9) is that defined by Friedlander 11:

$$
\mathrm{S}=\mathrm{C}_{\mathrm{gas}}(\mathrm{R} * \mathrm{~T}) /\left(\mathrm{p}_{\mathrm{sat}}(\mathrm{T})^{*} \mathrm{MW}\right)
$$

where,

$$
\begin{array}{ll}
\mathrm{S} & =\text { saturation ratio, } \\
\mathrm{MW} & =\text { molecular weight of }\left(\mathrm{MoO}_{3}\right)_{\mathrm{m}}(\mathrm{kg} / \mathrm{kgmole}), \\
\mathrm{R} & =\text { gas constant }\left(\mathrm{Pa}-\mathrm{m}^{3} / \mathrm{kgmole}-\mathrm{K}\right), \\
\mathrm{T} & =\text { temperature }(\mathrm{K}), \text { and } \\
\mathrm{p}_{\mathrm{sat}}(\mathrm{T}) & =\text { vapor pressure of }\left(\mathrm{MoO}_{3}\right)_{\mathrm{m}} \text { at temperature } \mathrm{T}
\end{array}
$$

The vapor pressure of $\left(\mathrm{MoO}_{3}\right)_{\mathrm{m}}$ was obtained from the $\mathrm{HSC}$ thermochemical computer code 9 .

Condensation to the wall will occur when the concentration in the gas exceeds the equilibrium vapor concentration at the given temperature. The rate of condensation given by Eq. (10) in that presented in Ref. [8]:

$$
\mathrm{J}_{\text {cond }}=\mathrm{k}\left(\mathrm{C}_{\mathrm{gas}}-\mathrm{C}_{\mathrm{equ}}\right)
$$

where,

$$
\begin{array}{ll}
\mathrm{J}_{\text {cond }} & =\text { condensation mass flux }\left(\mathrm{kg} / \mathrm{m}^{2}-\mathrm{s}\right) \\
\mathrm{k} & =\text { mass transfer coefficient }(\mathrm{m} / \mathrm{s}), \text { and } \\
\mathrm{C}_{\text {equ }} & =\text { equilibrium vapor concentration }\left(\mathrm{kg} / \mathrm{m}^{3}\right) .
\end{array}
$$

Using the ideal gas law to relate the equilibrium vapor concentration to the vapor pressure and the definition of supersaturation ratio, this relationship can be written as Eq. (11). 


$$
\mathrm{J}_{\mathrm{cond}}=\mathrm{k} \mathrm{A}_{\mathrm{s}} \mathrm{MW} \mathrm{p}_{\mathrm{sat}}(\mathrm{T})(\mathrm{S}-1) /(\mathrm{R} * \mathrm{~T})
$$

The mass transfer coefficient expressed as k in Eq. (12) is given by Bird[8]:

$$
\mathrm{k}=1.86 *(\mathrm{D} / \mathrm{d}) *[\operatorname{Re} * \operatorname{Sc}(\mathrm{L} / \mathrm{d})]^{0.333}
$$

where

$\operatorname{Re}=$ Reynolds number of the flow,

Sc $\quad=$ Schmidt number,

$\mathrm{D}=$ diffusion coefficient of $\left(\mathrm{MoO}_{3}\right)_{\mathrm{m}}$ in air given by the Chapman-Eskong theory which is also presented in Bird[8],

$\mathrm{d} \quad=$ diameter of tube, and

$\mathrm{L} \quad=$ length of tube from sample to location of interest along the tube.

Thus, the mass balance equations that describe the mass of $\left(\mathrm{MoO}_{3}\right)_{\mathrm{m}}$ condensed and in the vapor phase are:

$$
\begin{array}{ll}
\mathrm{dC}_{\mathrm{gas}} / \mathrm{dt} & =-\mathrm{J}_{\text {cond }} * \mathrm{~A}_{\text {wall }} / \mathrm{V} \\
\mathrm{dC}_{\text {cond }} / \mathrm{dt} & =\mathrm{J}_{\text {cond }} * \mathrm{~A}_{\text {wall }} / \mathrm{V}
\end{array}
$$

where

$\mathrm{A}_{\text {wall }} / \mathrm{V}=$ surface to volume ratio of pipe equals (4/d).

Converting the concentration in the gas to supersaturation yields Eq. (15)

$$
\mathrm{dS} / \mathrm{dt} \quad=\left(\mathrm{kA}_{\mathrm{wall}} / \mathrm{V}\right) *(\mathrm{~S}-1)
$$

Integration yields Eq. (16):

$$
S(t)=1-\left(S_{0}-1\right) \exp \left(-k A_{\text {wall }} * t / V\right)=1-\left(S_{0}-1\right) \exp (-4 k t / d),
$$

where $S_{o}$ is the initial supersaturation at the start of the collection tube. The collection tube is then discretized into an equal number of uniform cells (usually 100 over the length of the collection tube each $1 \mathrm{~cm}$ each). In this case $S_{0}$ is the initial supersaturation as the packet of gas enters the cell and $S(t)$ is set to the final value as it exits the $1-\mathrm{cm}$ long cell. This final value is given by Eq. (17):

$$
\mathrm{S}_{\text {final }}=1-\left(\mathrm{S}_{\mathrm{o}}-1\right) \exp (-4 \mathrm{k} \Delta \mathrm{t} / \mathrm{d})=1-\left(\mathrm{S}_{\mathrm{o}}-1\right) \exp \left(-4 \mathrm{kV} \mathrm{V}_{\mathrm{i}} / \mathrm{Q} * \mathrm{~d}\right)
$$

where

$\Delta \mathrm{t} \quad=$ time for the packet to transit the cell,

$\mathrm{V}_{\mathrm{i}} \quad=$ volume of segment $\mathrm{i}$, and

$\mathrm{Q} \quad=$ volumetric flow rate. 
And the mass condensed in a given cell is given by Eq. (18):

$$
\left[\mathrm{S}_{\mathrm{final}}-\mathrm{S}_{\mathrm{o}}\right]^{*} \mathrm{p}_{\mathrm{sat}}(\mathrm{T}) * \mathrm{MW} /[\mathrm{R} * \mathrm{~T}]
$$

The final supersaturation exiting a cell is the initial supersaturation entering the next cell in the collection tube. Temperatures in the tube for each test were linearly fit (piecewise into two or three pieces in some cases to get the best fit) and then the linear fit was used in the calculations. The $\left(\mathrm{MoO}_{3}\right)_{\mathrm{m}}$ deposition was converted to molybdenum by multiplying by the ratio of the molecular weights. The measured and calculated depositions were converted to deposition per unit length given the limited number of measurements and the large variation in the calculated deposition along the tube.

The results for various cases of temperatures, flow rates and times as listed in Table 3 are shown in Figures 18(a) through Figure 18(h).

Table 3. Cases calculated by deposition model.

\begin{tabular}{cccc} 
Case Number & Temperature $\left({ }^{\circ} \mathrm{C}\right)$ & Flow rate of Air (slpm) & Duration (hr) \\
\hline 1 & 800 & 1 & 1 \\
2 & 700 & 0.5 & 2 \\
3 & 700 & 2.5 & 2 \\
4 & 700 & 1 & 2 \\
5 & 650 & 1 & 8 \\
6 & 600 & 1 & 8 \\
7 & 600 & 1 & 24 \\
8 & 500 & 1 & 24
\end{tabular}

The results show that the start of condensation is very well predicted with the model for all the cases. The peak deposition is well predicted in the majority of cases (e.g., Cases 2, 3, 5 and 7) and in the worst cases overpredicts the peak deposition by between 50 and 100\%. The deposit model predicts a broad tail of deposition beyond the peak deposition location. This broad tail in most cases overpredicts the observed deposition in the tube. Deviations in the peak heights and the broad tail distribution can be explained by deposition occurring at preferential macroscopic sites provided by growing crystals. For example, this is most apparent for the $800^{\circ} \mathrm{C}$ test that had crystals bridging the I.D. and nearly plug the tube. Deposition on these crystals would substantially deplete the $\left(\mathrm{MoO}_{3}\right)_{\mathrm{m}}$ concentration causing lower than predicted deposition in downstream locations. The experimental data also showed significant molybdenum deposition near the end of the tube and in the glass wool. This deposition was bluish colored and SEM showed that the deposition in the quartz wool consisted of agglomerated small particles. We might expect particle nucleation and transport upon cooling the supersaturated gas. Such aerosol formation was not considered in the model. Had nucleation been incorporated into the model, some of the condensation would have occurred onto those nucleated particles decreasing the 
calculated condensation onto the tube in regions where supersaturation is high enough to support both nucleation and condensation onto both particle and walls. The role of $\mathrm{MoO}_{2}(\mathrm{OH})_{2(\mathrm{~g})}$ was also not considered. Decomposition of this vapor at lower temperatures may have produced the oxide with the bluish color. This latter mechanism also provides an explanation for the large discrepancy for the $500^{\circ} \mathrm{C}$ test, i.e., Case 8. Most of the molybdenum is shown to be volatilized as $\mathrm{MoO}_{2}(\mathrm{OH})_{2(\mathrm{~g})}$ in Section 3.3 rather than $\left(\mathrm{MoO}_{3}\right)_{\mathrm{m}}$. Analyses from the ICP-AES showed that most of the re-deposited oxide was in the reaction chamber as reported in Appendix C. In conclusion, given the simplicity of the model, it does a reasonable job at broadly describing deposition behavior at $600^{\circ} \mathrm{C}$ and higher where volatilization is dominated by $\left(\mathrm{MoO}_{3}\right)_{\mathrm{m}}$.

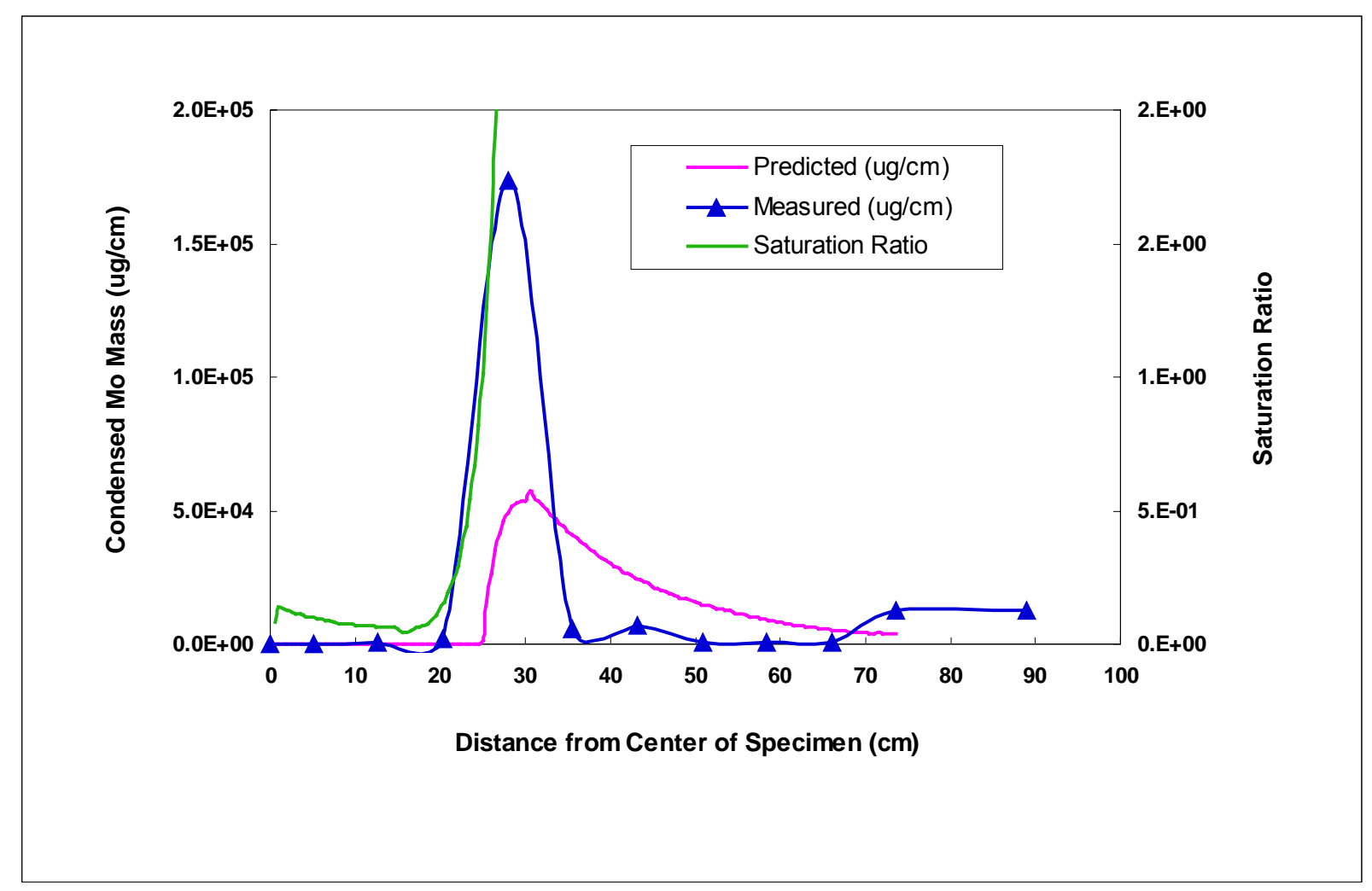

Figure 18(a). Case 1 -Test at $800^{\circ} \mathrm{C}$ with one liter per minute flow rate for one hour. 


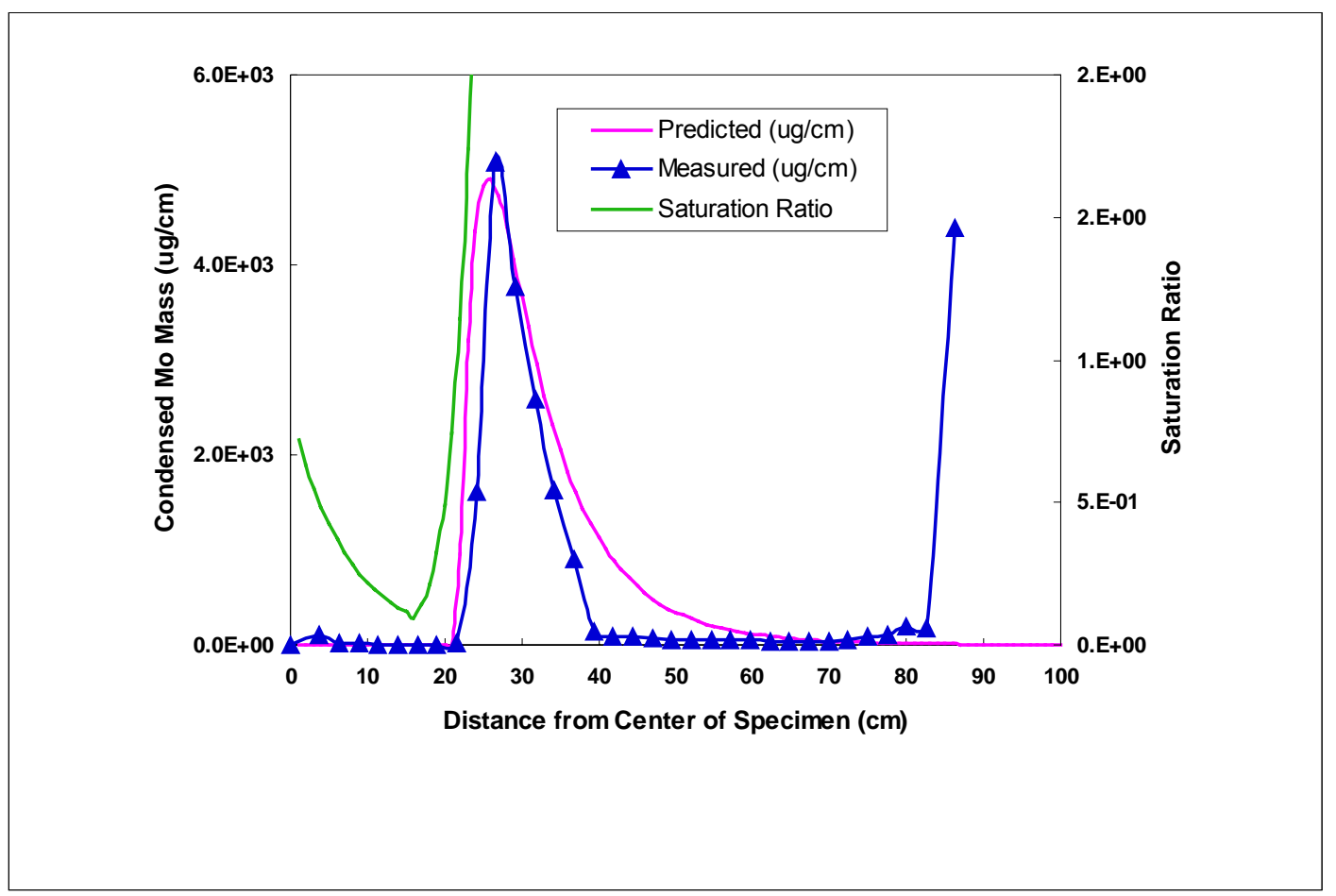

Figure 18(b). Case $2-$ Test at $700^{\circ} \mathrm{C}$ with 0.5 liter per minute flow for two hours.

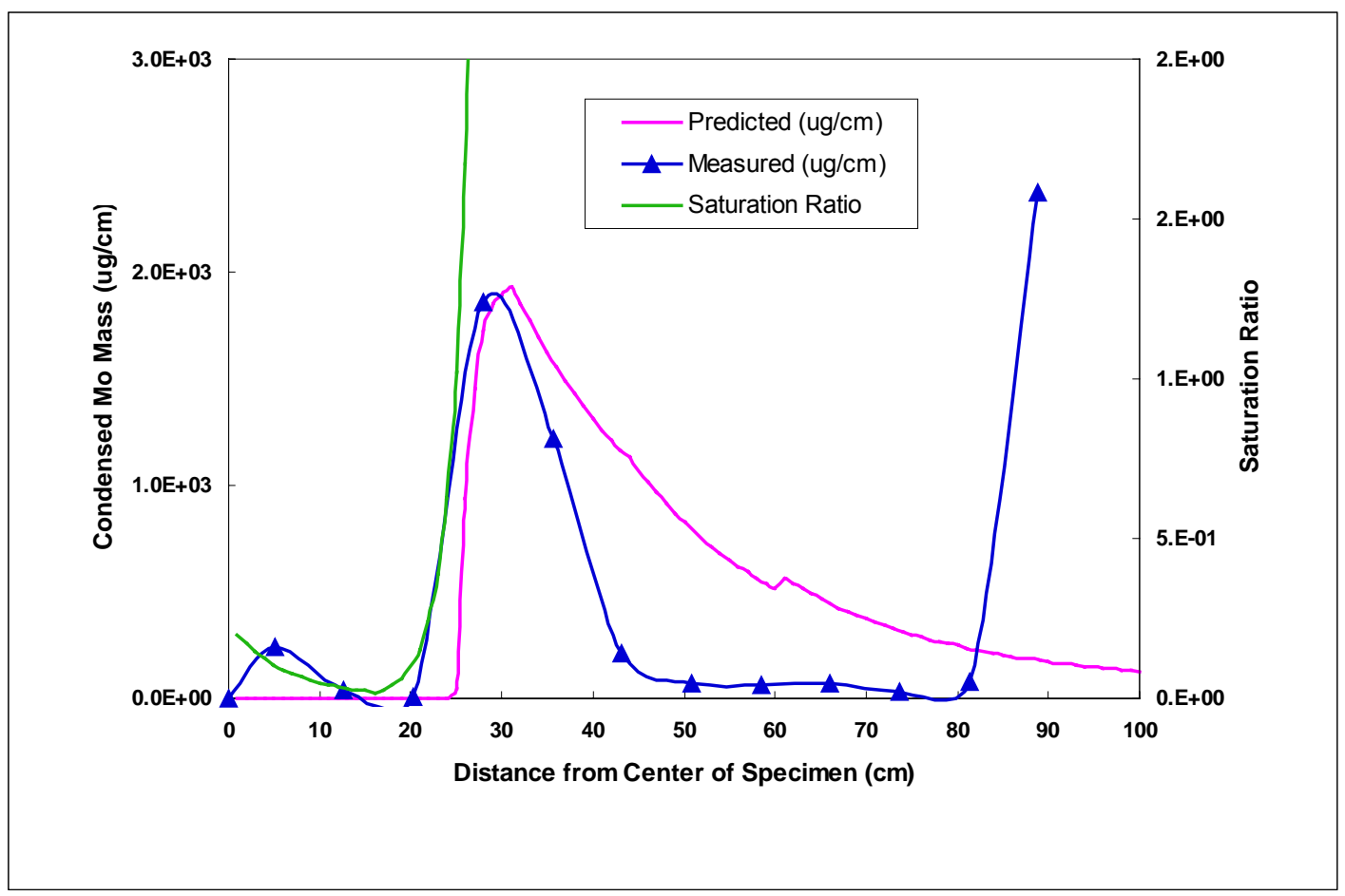

Figure 18(c). Case $3-$ Test at $700^{\circ} \mathrm{C}$ with 2.5 liter per minute flow for two hours. 


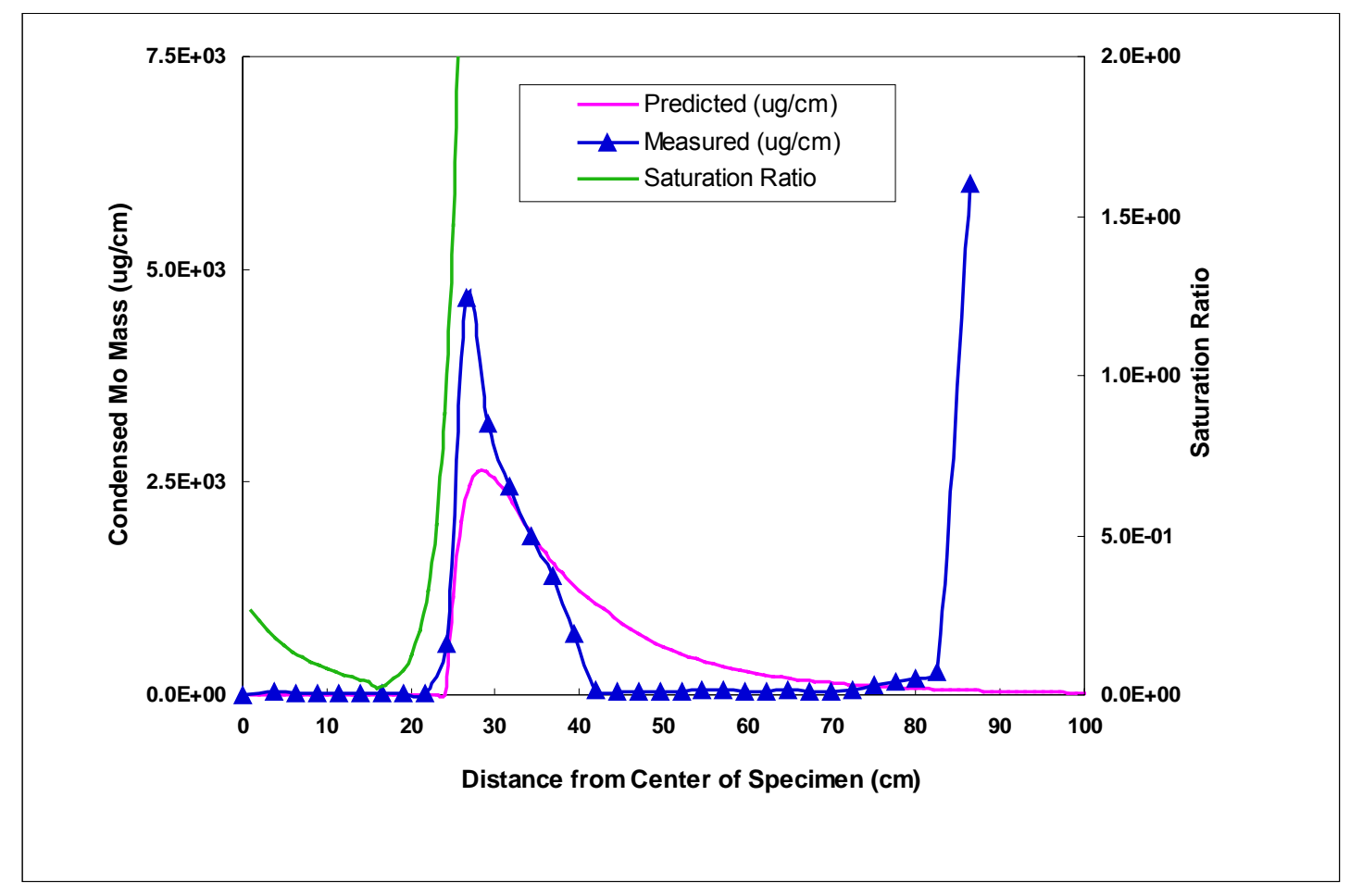

Figure 18(d). Case $4-$ Test at $700^{\circ} \mathrm{C}$ with one liter per minute flow for two hours.

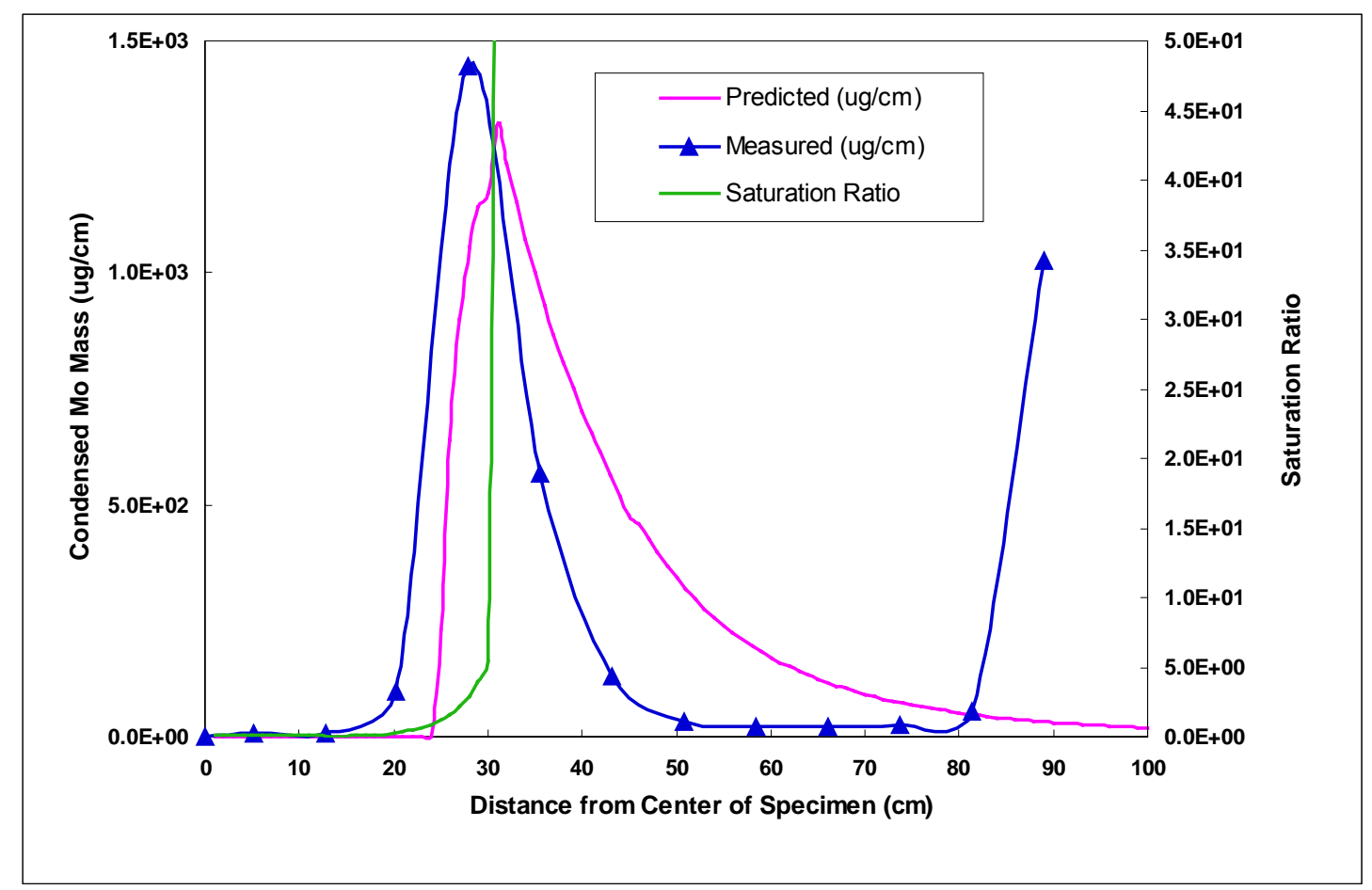

Figure 18(e). Case $5-$ Test at $650^{\circ} \mathrm{C}$ with one liter per minute flow rate for 8 hours. 


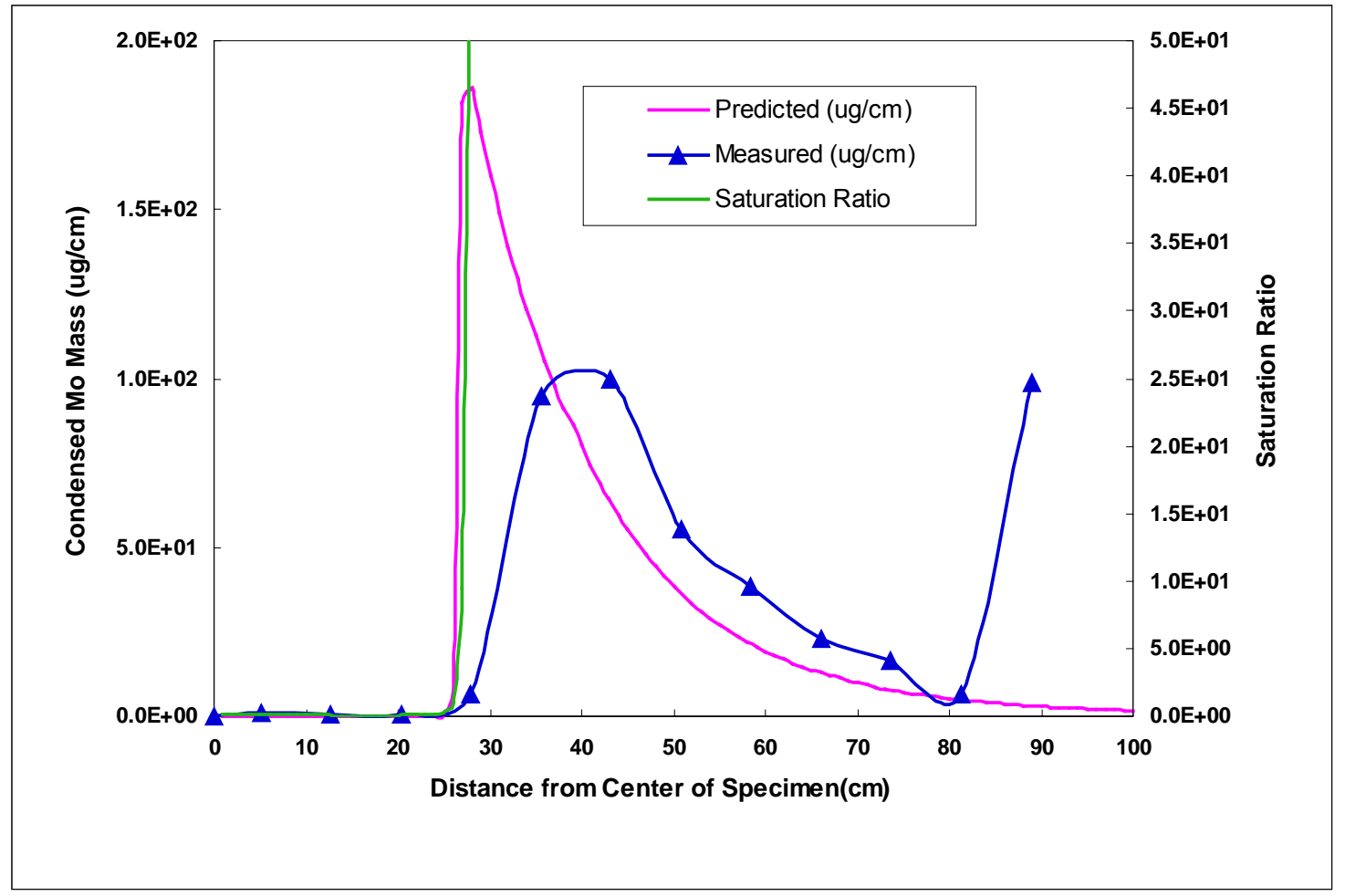

Figure 18(f). Case 6 - Test at $600^{\circ} \mathrm{C}$ with one liter per minute flow for 8 hours.

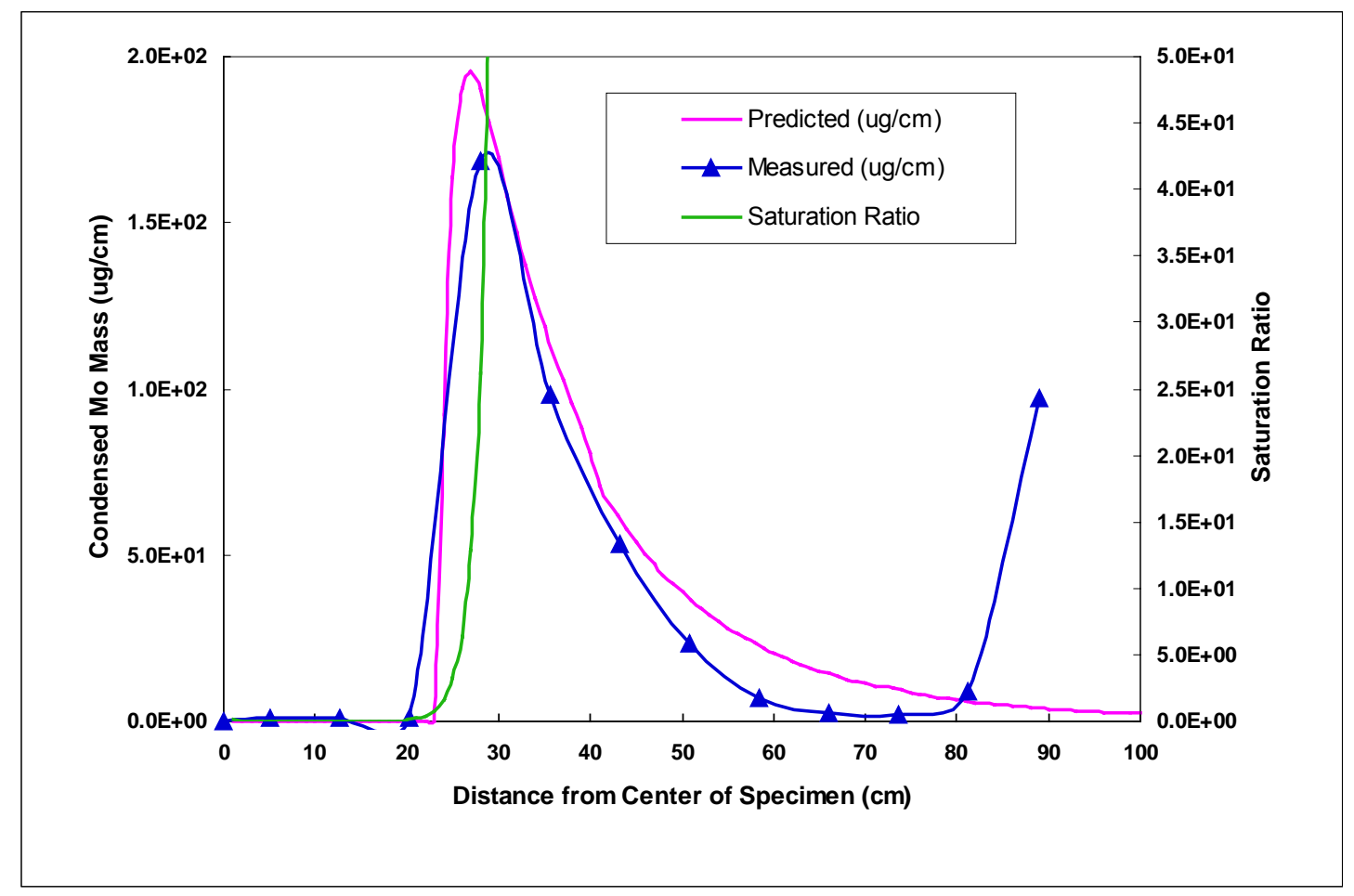

Figure 18(g). Case $7-$ Test at $600^{\circ} \mathrm{C}$ with one liter per minute flow rate for 24 hours. 


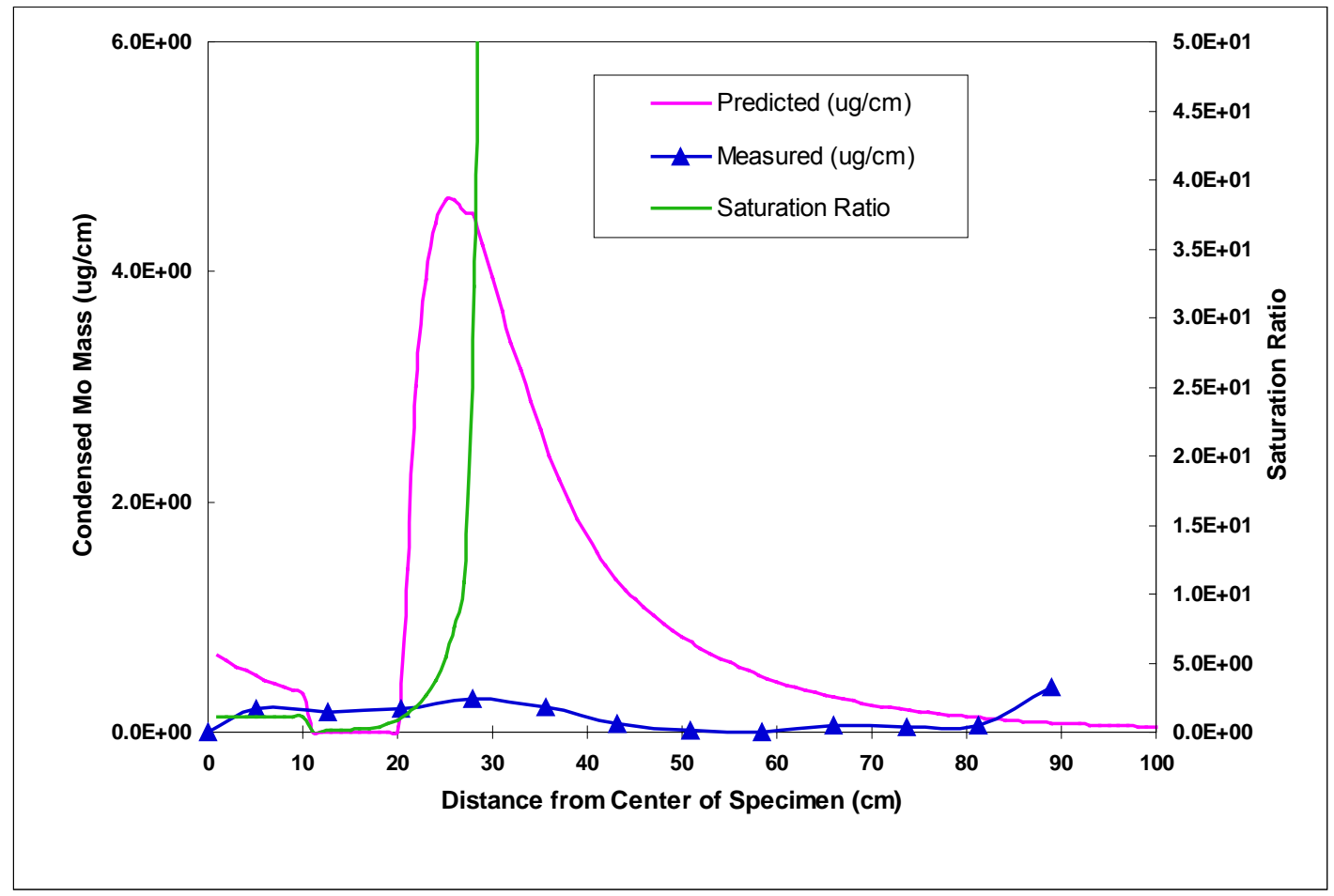

Figure 18(h). Case 8 - Test at $500^{\circ} \mathrm{C}$ with one liter per minute flow rate for 24 hours.

\subsection{MOBILITY-BASED DOSE DERIVED FROM OXIDATION DRIVEN VOLATILITY}

We can use the oxidation-driven mobilization data to calculate a mobility-based dose. This dose can be used as a metric to compare with other fusion materials or with appropriate confinement factors used in a safety analysis of a conceptual fusion design.

The fractional rate of mobilization of a particular element in an alloy at a given temperature is calculated using the Eq. (19): $\frac{12}{12}$

$$
\dot{M F}=\frac{\Gamma}{W P \times \rho \times \delta}
$$

where $\dot{M F}$ is the mobilization fraction per unit time, $\Gamma$ is the cumulative mass flux of the element $\left(\mathrm{kg} / \mathrm{m}^{2}-\mathrm{s}\right)$ based on the test data, WP is the weight fraction of the element in the material, $\rho$ is the density of the material $\left(\mathrm{kg} / \mathrm{m}^{3}\right)$, and $\delta$ is the thickness of the component $(\mathrm{m})$ that is being analyzed.

The oxidation-driven mobility-based dose rate is then given by the following equation:

$$
\text { DoseRate }=[R I \times D I] \times \dot{M} F \times A_{F W} \times \rho \times \delta
$$


where,

$\mathrm{RI}=$ radioactive inventory of isotope per unit mass of material $(\mathrm{Bq} / \mathrm{kg})$ in the component,

$\mathrm{DI}=$ dose impact of isotope $(\mathrm{Sv} / \mathrm{Bq})$,

$\mathrm{A}_{\mathrm{FW}}=$ surface area of first wall $\left(\mathrm{m}^{2}\right)$.

The inner summation is over all isotopes produced and the outer summation is over all of the elements in the alloy.

Thus, the dose rate is simply given by:

$$
\text { DoseRate }=\frac{[R I \times D I] \times \Gamma \times A_{F W}}{W P}
$$

For the TZM alloy, an activation calculation for the first wall based on the EVOLVE design assuming TZM as the first wall structural material was used. The dose impact of each isotope was calculated for both ground level and elevated releases using conservative meteorology (class $\mathrm{F}$ and $1 \mathrm{~m} / \mathrm{s}$ wind speed as needed in a traditional "design basis" safety analysis), and using best estimate meteorology (class D and $4 \mathrm{~m} / \mathrm{s}$ wind speed as needed in a no-evacuation assessment). 14 A one-kilometer site boundary and the regulatory-accepted Pasquill-Gifford dispersion set were used in the evaluation. All results are early doses (7-day exposure) to the maximum exposed individual (at the site boundary for the ground level cases and where the plume touches the ground for the elevated releases). These data are reproduced in Table 4.

Table 4. Radioactive inventory and Dose Impact of Mo and Tc Isotopes.

\begin{tabular}{|c|c|c|c|c|}
\hline Isotope & $\begin{array}{l}\text { Radioactive } \\
\text { Inventory } \\
(\mathrm{Ci} / \mathrm{g})\end{array}$ & $\begin{array}{l}\text { Dose Impact } \\
\mathrm{D} \text { and } 4 \mathrm{~m} / \mathrm{s} \\
\text { Ground level } \\
(\mathrm{Sv} / \mathrm{TBq})\end{array}$ & $\begin{array}{l}\text { Dose Impact } \\
\mathrm{D} \text { and } 4 \mathrm{~m} / \mathrm{s} \\
\text { Elevated } \\
(\mathrm{Sv} / \mathrm{TBq})\end{array}$ & $\begin{array}{c}\text { Dose Impact } \\
\mathrm{F} \text { and } 1 \mathrm{~m} / \mathrm{s} \text { Ground } \\
\text { level } \\
(\mathrm{Sv} / \mathrm{TBq})\end{array}$ \\
\hline Mo 93 & $2.60 \mathrm{E}-03$ & $4.10 \mathrm{E}-05$ & $3.72 \mathrm{E}-06$ & $4.26 \mathrm{E}-04$ \\
\hline Mo 93m & $1.35 \mathrm{E}-02$ & 5.43E-07 & $4.89 \mathrm{E}-08$ & $5.53 \mathrm{E}-06$ \\
\hline Mo 99 & $2.13 \mathrm{E}-01$ & $6.98 \mathrm{E}-06$ & $6.38 \mathrm{E}-07$ & $7.23 \mathrm{E}-05$ \\
\hline Mo101 & $1.83 \mathrm{E}-01$ & $5.45 \mathrm{E}-08$ & $7.01 \mathrm{E}-09$ & 2.69E-07 \\
\hline Tc 98 & $1.81 \mathrm{E}-07$ & $4.66 \mathrm{E}-05$ & $4.27 \mathrm{E}-06$ & $4.83 \mathrm{E}-04$ \\
\hline Tc 99 & $4.88 \mathrm{E}-05$ & $8.01 \mathrm{E}-06$ & $7.28 \mathrm{E}-07$ & $8.34 \mathrm{E}-05$ \\
\hline Tc $99 \mathrm{~m}$ & $2.80 \mathrm{E}+00$ & $1.81 \mathrm{E}-07$ & $1.97 \mathrm{E}-08$ & $1.73 \mathrm{E}-06$ \\
\hline Tc101 & $1.83 \mathrm{E}-01$ & $7.01 \mathrm{E}-09$ & $8.44 \mathrm{E}-10$ & $3.20 \mathrm{E}-08$ \\
\hline \multicolumn{2}{|c|}{$\begin{array}{l}\text { All Mo isotope contribution to } \\
\text { dose }(\mathrm{Sv} / \mathrm{g})^{*}\end{array}$} & $5.97 \mathrm{E}-08$ & $5.46 \mathrm{E}-09$ & $6.16 \mathrm{E}-07$ \\
\hline \multicolumn{2}{|c|}{$\begin{array}{l}\text { All Tc isotope contribution to } \\
\text { dose }(\mathrm{Sv} / \mathrm{g})^{*}\end{array}$} & $1.88 \mathrm{E}-08$ & $2.05 \mathrm{E}-09$ & $1.79 \mathrm{E}-07$ \\
\hline
\end{tabular}

* Calculated by summing the product of the radioactive inventory of an isotope and its dose impact. 
The mobilty-based dose rate for Mo from the TZM alloy is based on the cumulative maximum method from data presented in Table 2 in Section 3.1. Mobilization of the Tc isotopes produced by activation of the Mo is assumed to follow that of the Mo at all temperatures because of the very high vapor pressure of the technetium oxides. The other elements in the TZM alloy did not mobilize in the experiments because of their extremely low volatility and are not included in the evaluation. The results, based on a $500 \mathrm{~m}^{2}$ first wall with no radiological confinement, are shown in Table 5. They are compared graphically to the mobilization from tungsten alloy for two of the dose cases studied in Figures 19 and 20.

Table 5. Oxidation-driven Mobilization-base Dose Rates as a Function of Temperature Under Different Exposure Conditions.

\begin{tabular}{|c|c|c|c|}
\hline \multirow{2}{*}{} & \multicolumn{3}{|c|}{ Oxidation-driven Mobilization-based Dose Rate } \\
\cline { 2 - 4 } & $\begin{array}{c}\text { D\&4 m/s } \\
\text { Ground } \\
\text { Temperature }\left({ }^{\circ} \mathrm{C}\right)\end{array}$ & $\begin{array}{c}\text { D\&4 m/s } \\
\text { Elevated } \\
(\text { Sv/hr })\end{array}$ & $\begin{array}{c}\text { F\&1 m/s } \\
\text { Ground } \\
(\text { Sv/hr })\end{array}$ \\
\hline 400 & $2.37 \mathrm{E}-09$ & $2.27 \mathrm{E}-10$ & $2.40 \mathrm{E}-08$ \\
\hline 500 & $1.61 \mathrm{E}-07$ & $1.54 \mathrm{E}-08$ & $1.63 \mathrm{E}-06$ \\
\hline 600 & $1.57 \mathrm{E}-05$ & $1.50 \mathrm{E}-06$ & $1.59 \mathrm{E}-04$ \\
\hline 650 & $1.35 \mathrm{E}-04$ & $1.29 \mathrm{E}-05$ & $1.36 \mathrm{E}-03$ \\
\hline 700 & $1.40 \mathrm{E}-03$ & $1.34 \mathrm{E}-04$ & $1.42 \mathrm{E}-02$ \\
\hline 750 & $1.50 \mathrm{E}-02$ & $1.43 \mathrm{E}-03$ & $1.52 \mathrm{E}-01$ \\
\hline 800 & $9.51 \mathrm{E}-02$ & $9.10 \mathrm{E}-03$ & $9.64 \mathrm{E}-01$ \\
\hline
\end{tabular}

The results show that the mobilization dose for TZM alloy is about two orders of magnitude lower than that for tungsten below about $600^{\circ} \mathrm{C}$, and decreases to about one order of magnitude up to $800^{\circ} \mathrm{C}$. Above $800^{\circ} \mathrm{C}$, the Mo in the TZM that converts to molybdenum trioxide melts making measurements very difficult. The results can also be used to determine the degree of radiological confinement needed in accidents involving oxidation driven mobilization of material from the first wall. In a decay heat transient involving air ingress that reaches $750^{\circ} \mathrm{C}$ for five days, the oxidation driven mobilization dose would be approximately $2 \mathrm{~Sv}$ (see Figure 20). Thus, to meet a $10 \mathrm{mSv}$ no-evacuation dose would require the radiological confinement to reduce this source term by about a factor of 200 . After five days at $750^{\circ} \mathrm{C}$, approximately 70 percent of the affected first wall area would have been mobilized. Transients that result in shorter times at lower temperatures would require less radiological confinement to meet the noevacuation goal. If temperatures always remained below $500^{\circ} \mathrm{C}$ in a transient then this would not be a significant contribution to the off-site radiological source term in an accident.

\footnotetext{
${ }^{1}$ The concept of cumulative maximum is a conservative formulation used for safety assessments. The cumulative maximum mobility at temperature $\mathrm{X}$ is the maximum mobility measured at all temperatures up to and including $\mathrm{X}$. Thus, if the maximum mobility measured at $600^{\circ} \mathrm{C}$ is higher than the value measured at $700^{\circ} \mathrm{C}$, the value from the $600^{\circ} \mathrm{C}$ test is used in place of the value at $700^{\circ} \mathrm{C}$.
} 


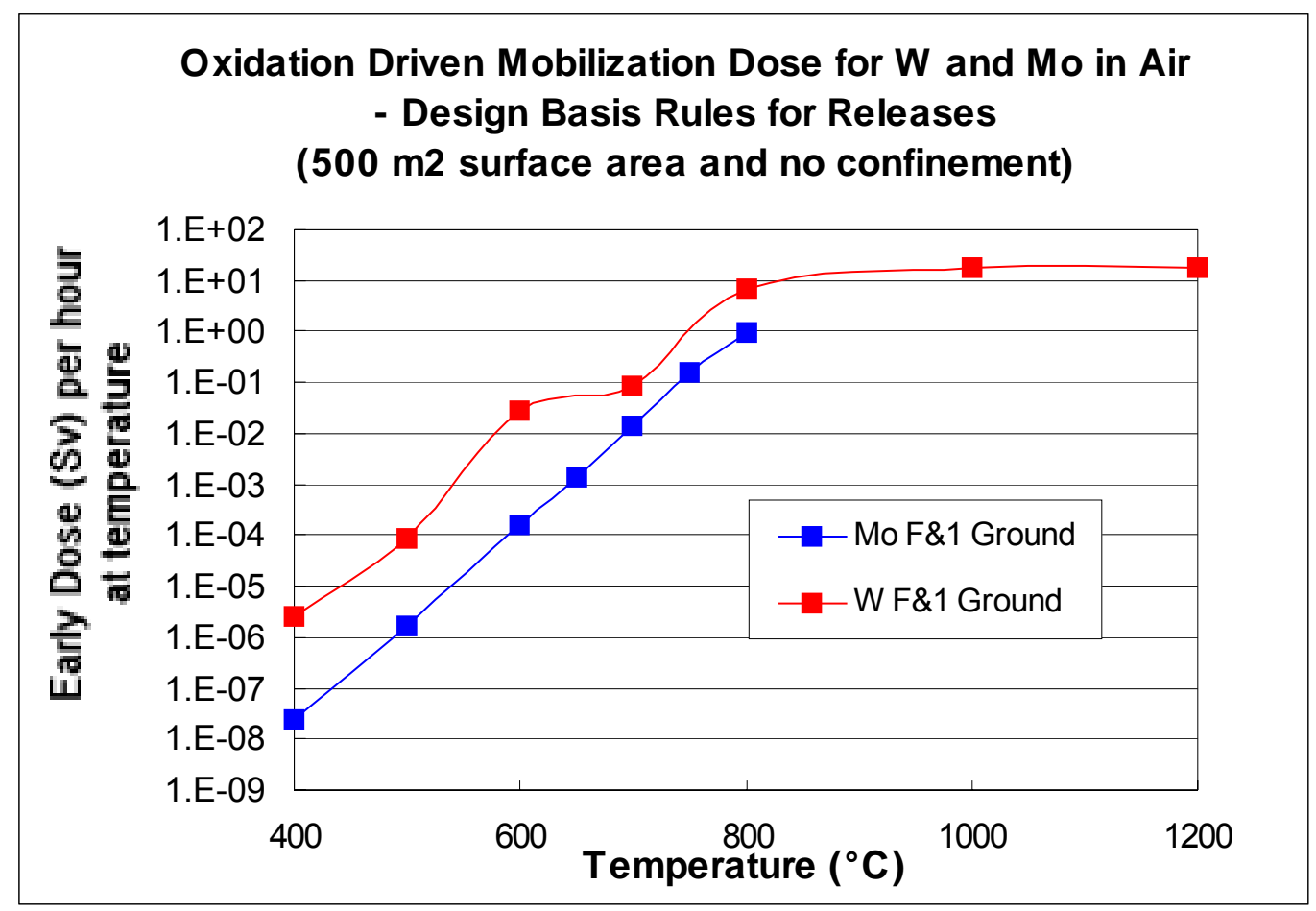

Figure 19. Oxidation driven mobilization doses for $\mathrm{W}$ and Mo in air. The design basis for release are $500 \mathrm{~m}^{2}$ surface area with no confinement.

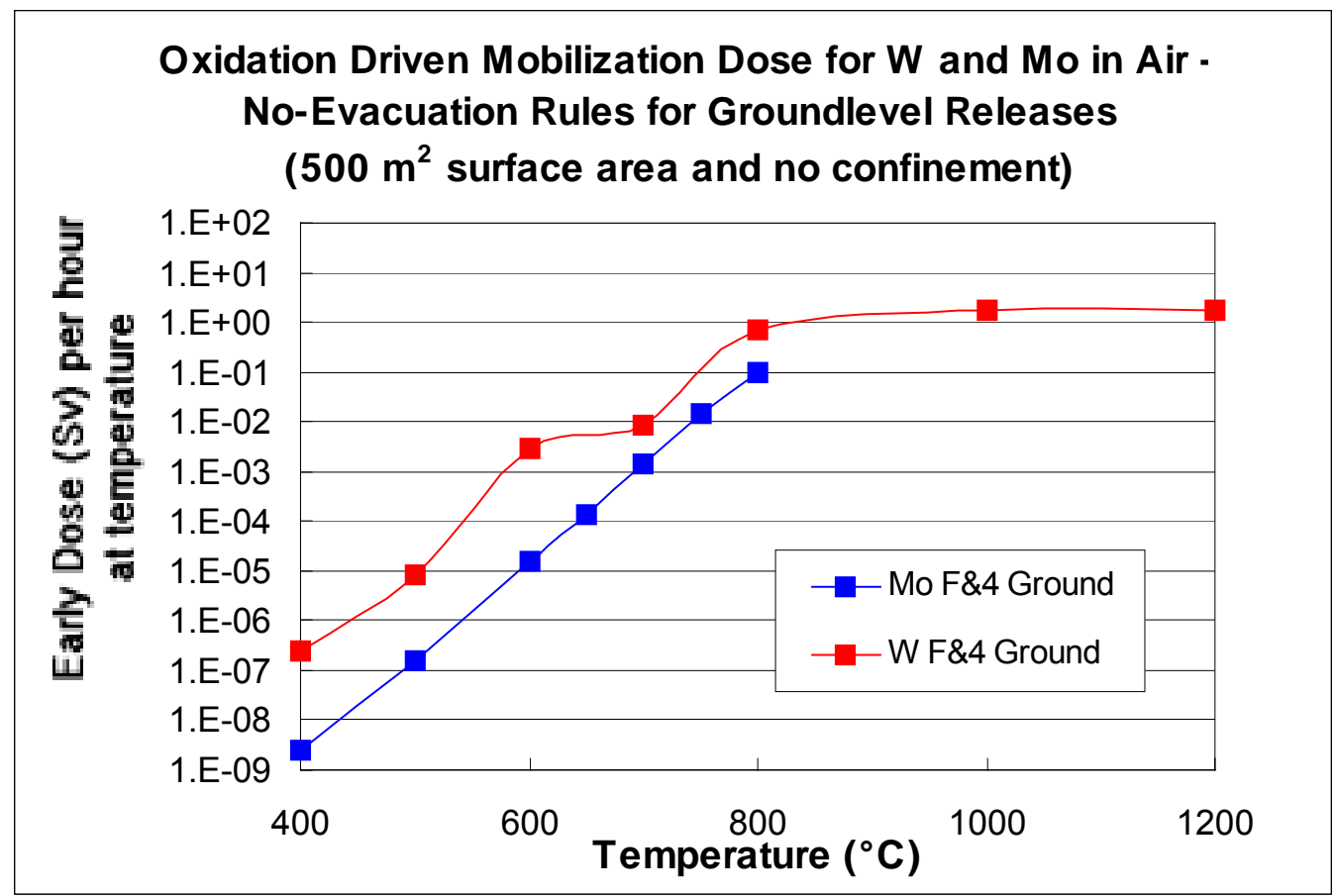

Figure 20. Oxidation driven mobilization doses for $\mathrm{W}$ and Mo in air. Releases are for $500 \mathrm{~m}^{2}$ surface area with no confinement and class D and $4 \mathrm{~m} / \mathrm{s}$ wind speed for no-evacuation criteria. 


\section{CONCLUSIONS}

We have observed good correlation between experimental volatilization rates and those predicted by our mass transport model. The volatilization process occurs by two different mechanisms at low and high temperatures. At low temperatures, e.g., below $550^{\circ} \mathrm{C}$ volatilization is dominated by $\mathrm{MoO}_{2}(\mathrm{OH})_{2(\mathrm{~g})}$ formed from even small concentrations of water vapor. Above this temperature volatilization occurs predominately by the volatile $\left(\mathrm{MoO}_{3}\right)$ polymeric species. Our model accounted for both of these mechanisms in the two different temperature regions. It can therefore be used to accurately predict molybdenum mobilization for different climatic conditions, or ambient and humidity conditions of the air, involved in the ingress accident. The model also proved capable of accounting for flow rates which affected near-surface partial saturation of the volatilizing species and reduced mobilization.

The oxidation rate $(\mathrm{mm} / \mathrm{h})$ as indicated by recession, i.e., the amount of metal reacted, shows an increasing trend to $650^{\circ} \mathrm{C}$, then a slight decrease, and then sharply higher rates due to high volatilization. This trend with a maximum near $650^{\circ} \mathrm{C}$ simulates that observed with other refractory metals and has been associated with different oxide types. The higher oxidation rates at higher temperature, e.g., 700 to $800^{\circ} \mathrm{C}$ are due to the very high volatilization rates of the molybdenum trioxide.

Our model for the re-deposition of volatilized molybdenum species of $\left(\mathrm{MoO}_{3}\right)$ accurately predicted the downstream peak-deposition locations. The model provided best results for the higher temperatures where volatilization by the various polymeric forms of $\left(\mathrm{MoO}_{3}\right)$ is dominant. Differences between predicted and experimental peak heights and subsequent deposition profiles resulted when extensive crystal growth at the peak-deposition locations provided greatly increased surface area for re-deposition to occur.

Mobility-based dose calculations derived from oxidation-driven mobilization data showed TZM alloy to have lower radiological dose impact than tungsten at comparable temperatures and conditions. Dose levels from TZM alloy were two orders of magnitude lower below $600^{\circ} \mathrm{C}$ and about one order of magnitude lower at $800^{\circ} \mathrm{C}$. 


\section{REFERENCES}

1 Gulbranson, et al., J. Electrochemical Soc.110 (1963) 952-959.

2 J. N,. Ong, Jr. and W. M Fassell, Jr., Corrosion, $\underline{18}$, (1962) 382t-389t.

3 Kofstad, P., J. Inst. of Metals, 90, (1962) 253-264.

4 D.R. Olander and J. L. Schofill, Jr., Metallurgical Transactions, 1 (1970) 2775-2784.

5 M. Simnad and A. Spilners, J. Metals, $\underline{7}$, (1955) 1011-1016.

6 R. Speiser and G.R. St. Pierre, in The Science ad Technology of Tungsten, Tantalum, Molybdenum, Niobium and Their Alloys ed. by N.E.Promisel, Pergamon Press (1964) 289-330.

7 D. A. Petti, G. R. Smolik, and K. A. McCarthy, Tungsten Mobilization During Steam Between 400 and $1200^{\circ} \mathrm{C}, 20^{\text {th }}$ SOFT, Sept. 9-11,1998, Marseille, France 1483-1486.

8 R. B. Bird, W. E. Steward and E. N. Lightfoot, “Transport Phenomena”, John Wiley and Sons (1960).

9 A. Roine, Outokumpu HSC Chemistry for Windows, Version 2.0 (1994)

10 Unpublished work by J.D. Christian at the INEEL.

11 S.K. Friedlander, "Smoke, Dust, and Haze: Fundamentals of Aerosol Behavior", John Wiley and Sons, New York (1977).

12 K. A. McCarthy, G. R. Smolik, and S. L. Harms, "A Summary and Assessment of Oxidation Driven Volatility Experiments at the INEL and Their Application to Fusion Reactor Safety Assessments," EGG-FSP-11193, September 1994

13 Unpublished calculations performed by $\mathrm{H}$. Khater at U-Wisconsin Madison Fusion Institute.

14 M. Abbott letter to D. A. Petti, "Revised Results - MACCS2 Doses for Fusion Isotopes

Release to the Atmosphere using P-G Dispersion Parameters," MLA-11-99, April 14, 1999.

15 R. G. Bennett, J. D. Christian, D. A. Petti, W. K. Terry, and S. B. Grover, "A System of Tc99m Production Based on Distributed Electron Accelerators," Nuclear Technology, Vol. 126, No. 1, April 1999. 


\section{APPENDIX A}

\section{DESCRIPTIONS OF MOLYBDENUM OXIDE PRODUCTS DEPOSITED IN QUARTZWARE TEST COMPONENTS}




\section{Description of Oxidation Products from TZM _ 14}

Test temperature $\left({ }^{\circ} \mathrm{C}\right) \_\underline{400} \quad$ Time $(\mathrm{h}) \_\underline{24} \quad$ Flow rate (lpm) $\_\underline{1}$ Specimen mass (g): Initial __ 13.6641_ Final _ 13.6684_ Mass gain _

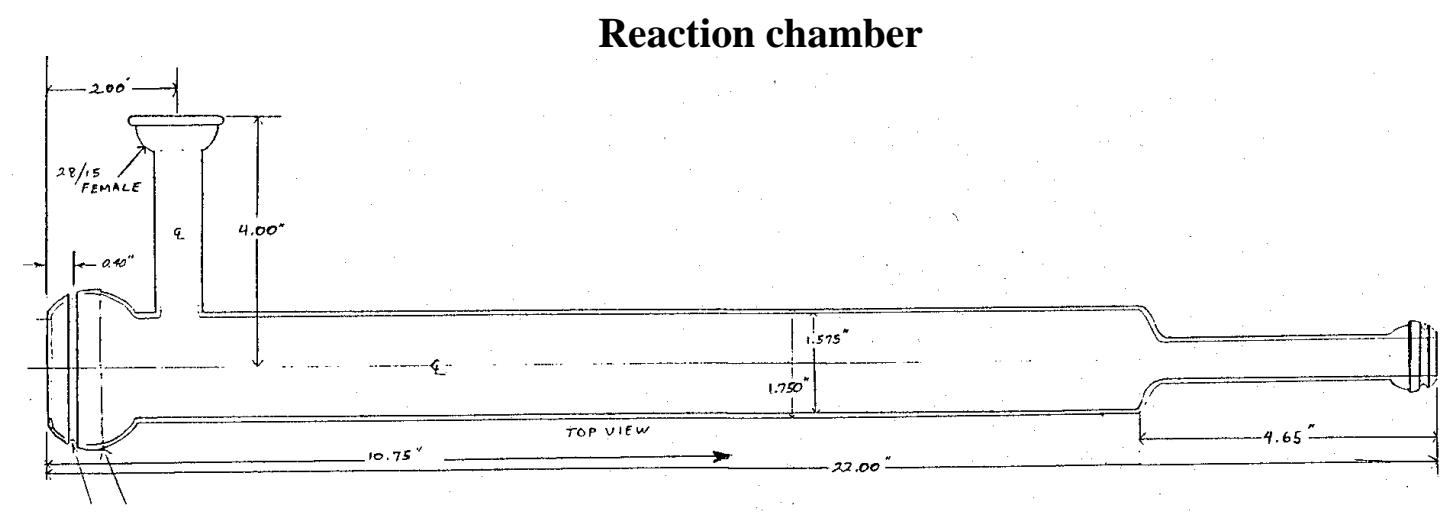

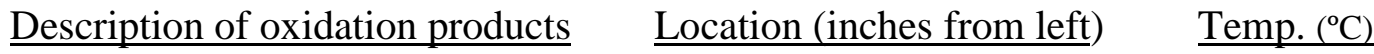

1. Clear, there is no evidence of any reaction product in test chamber.

2.

3.

4.

Deposition chamber

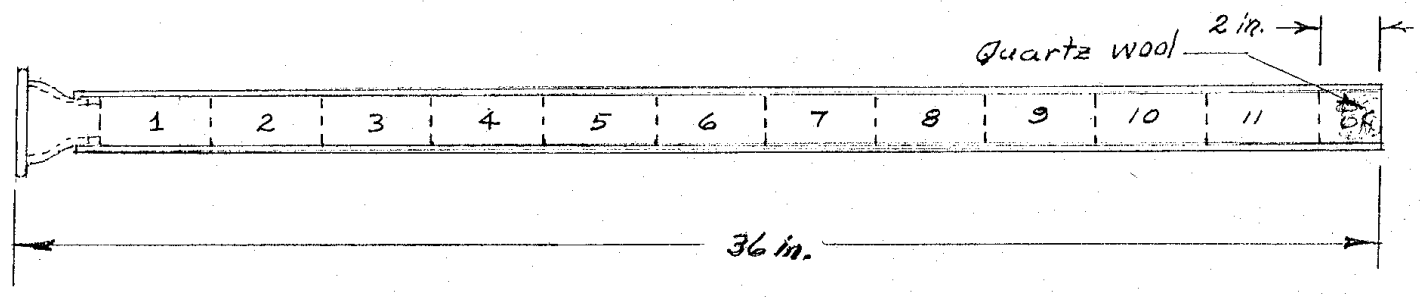

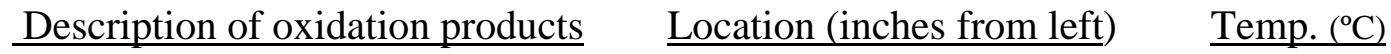

1. Clear, there is no evidence of any reaction products in collection tube, inserts, or quartz wool filter.

2.

3.

4.

5. 


\section{Description of Oxidation Products from TZM _ 1}

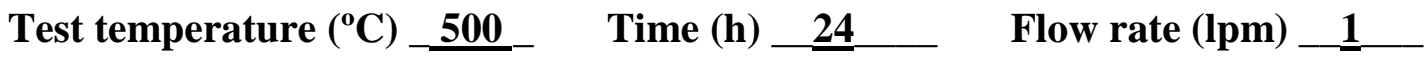
Specimen mass (g): Initial__6.6733 $\quad$ Final $\underline{\mathbf{6 . 7 4 2 9}}$ Mass gain $\underline{\mathbf{0 . 0 6 9 6}}$

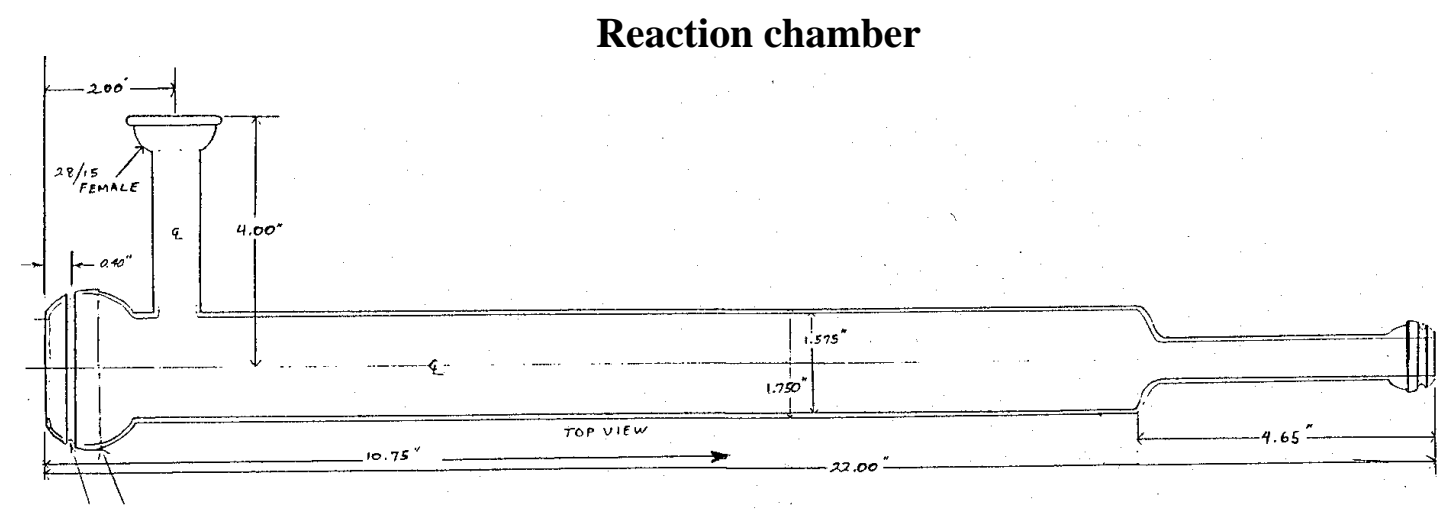

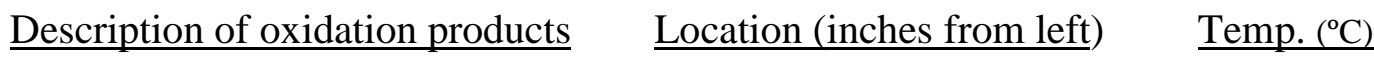

1. Nothing apparent in the reaction chamber

\section{Deposition chamber}

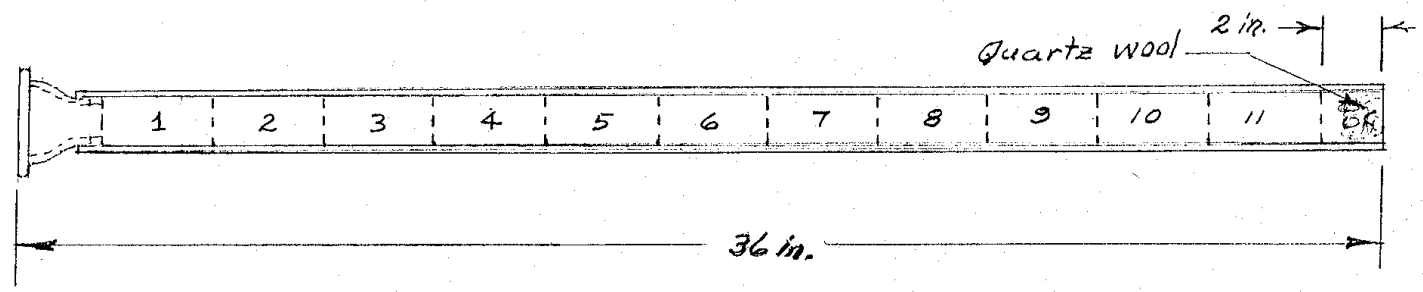

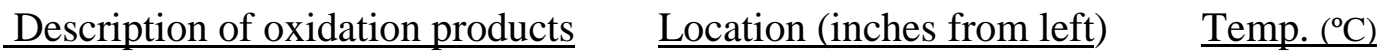

1. Clear to 4.5 inches

2. Light smoky deposit (insert I2)

4.7 to 7

3. Lighter smoky deposit (I3 and I4)

7 to 15.5

4. Slight color (on I5 and I6)

15.5 to 16.5

5. Nothing apparent ( I7 to I9)

16.5 to 25

6. Very slight coloring (I9 and I11)

25 to 31.5

7. Nothing apparent on quartz wool 


\section{Description of Oxidation Products from TZM _}

Test temperature $\left({ }^{\circ} \mathrm{C}\right) \_\underline{500} \quad$ Time $(\mathrm{h}) \_\underline{24} \quad$ Flow rate (lpm) $\_\underline{1}$ Specimen mass (g): Initial _ $\underline{\mathbf{1 3 . 8 8 2 7}}$ Final $\underline{\mathbf{1 3 . 9 4 6 4 3}}$ Mass gain _ $\underline{\mathbf{0 . 0 6 3 7 3}}$

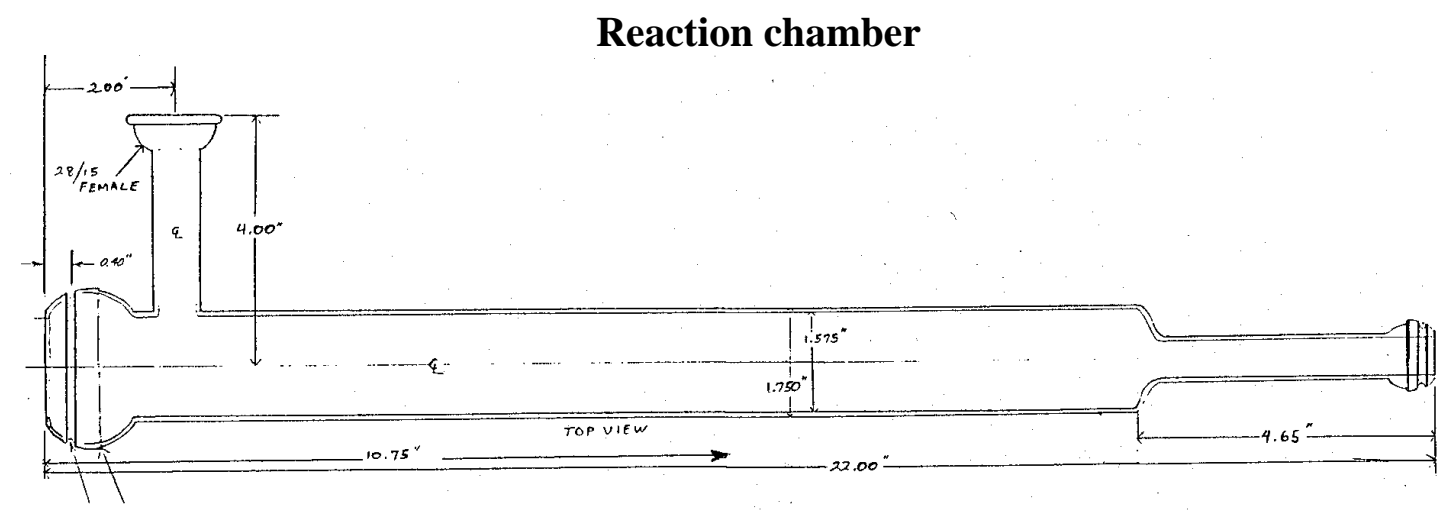

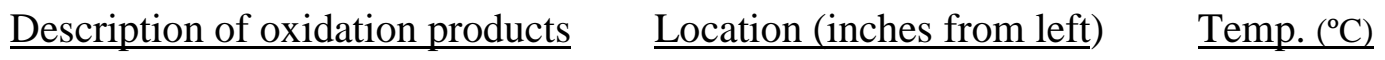

1. Clear, there is no evidence of any reaction product in test chamber.

2.

3.

4.

Deposition chamber

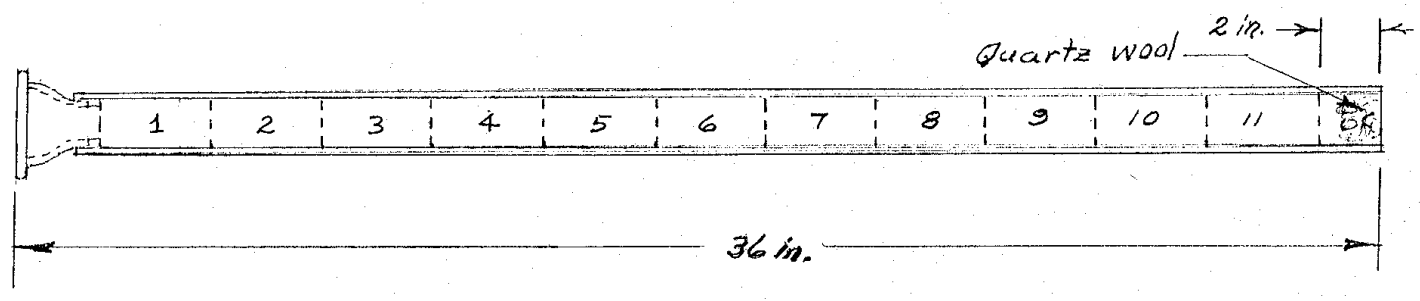

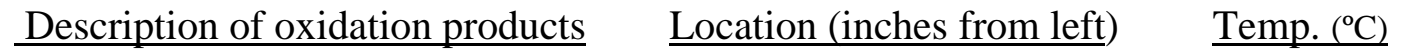

1. Clear, there is no evidence of any reaction products in collection tube, inserts, or quartz wool filter.

2.

3.

4.

5 .

6. 
Test temperature $\left({ }^{\circ} \mathrm{C}\right){ }_{-550}^{55} \quad$ Time (h) $\_\underline{\mathbf{2 4}}$ _ Flow rate (lpm)

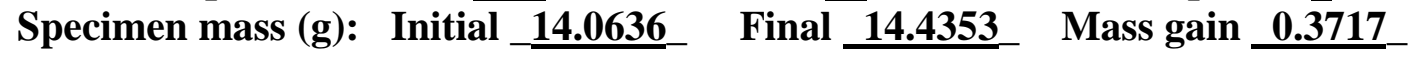

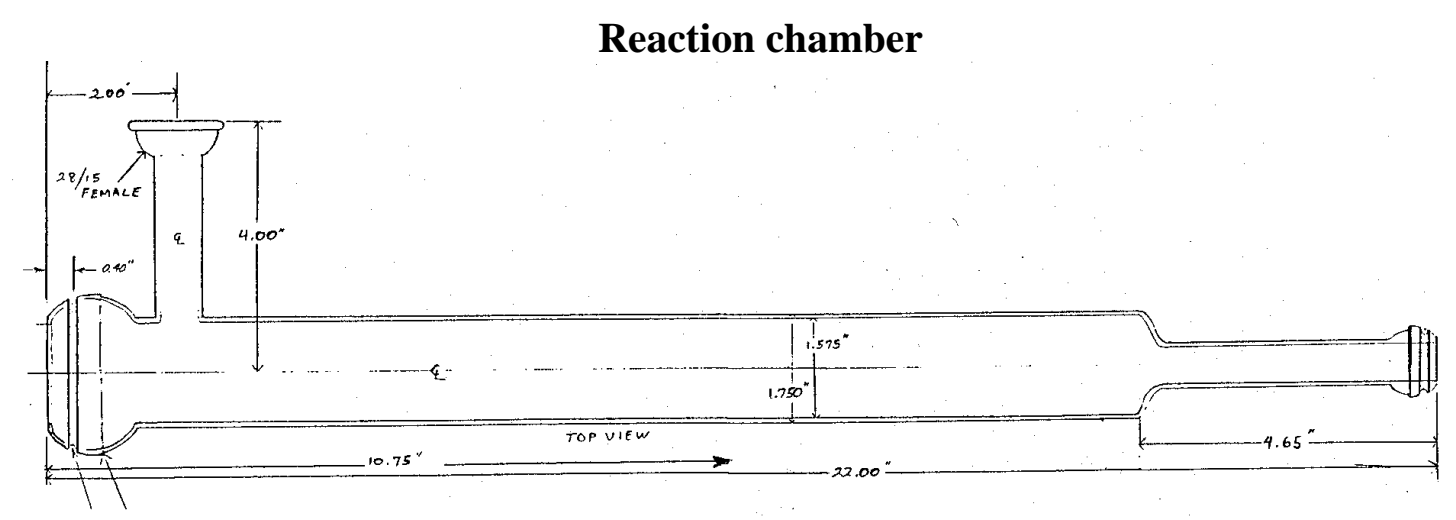

Description of oxidation products $\quad$ Location (inches from left) $\quad \underline{\text { Temp. }\left({ }^{\circ} \mathrm{C}\right)}$

1. Nothing apparent

\section{Deposition chamber}

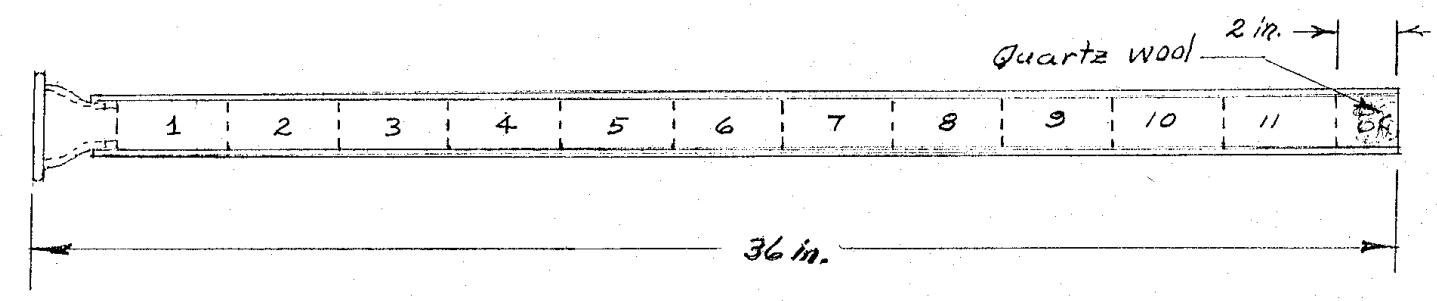

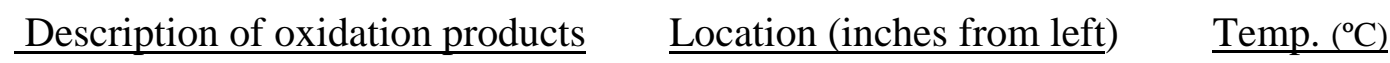

1. Clear for first 12.5 inches

2. Light smoky color (E4 thru E6)

12.5 to 18.5

3. Light smoky to light blue

18.5 to 21

4. Very light blue deposit

21 to 22

5. Clear

22 to 31

6. Very light bluish hue

31 to quartz wool 


\section{Description of Oxidation Products from TZM _}

Test temperature $\left({ }^{\circ} \mathrm{C}\right) \_\underline{600} \quad$ Time (h) $\_\underline{8} \quad$ Flow rate (lpm) $\_\underline{1 \mathrm{lpm}}$ Specimen mass (g): Initial__13.15934_ Final__13.35724_ Mass gain _

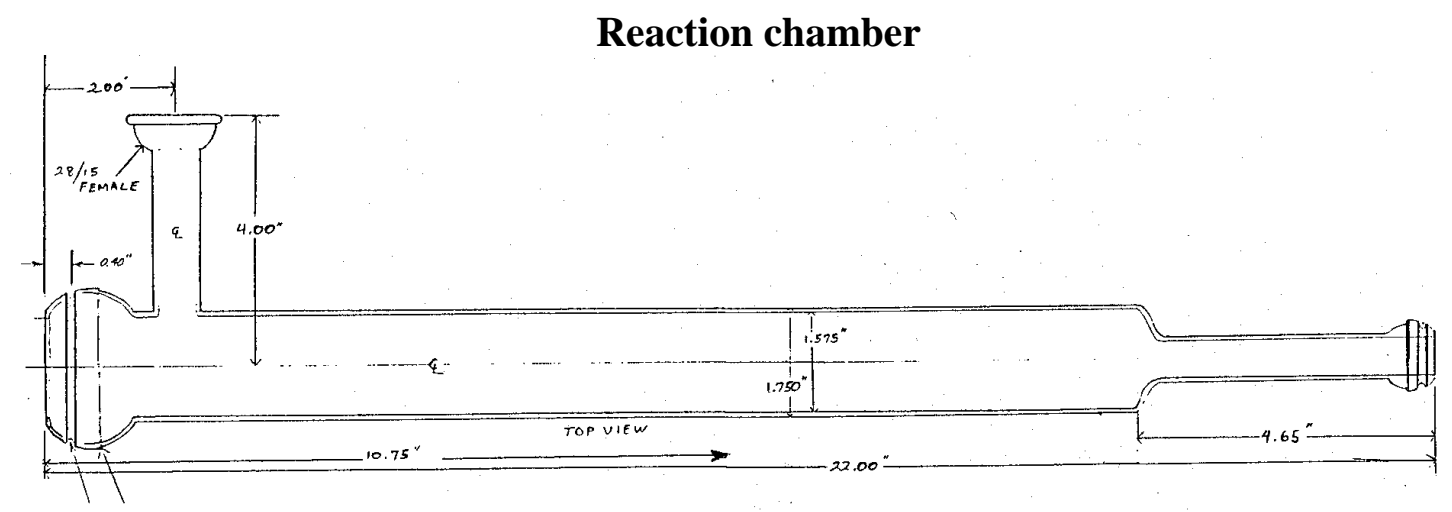

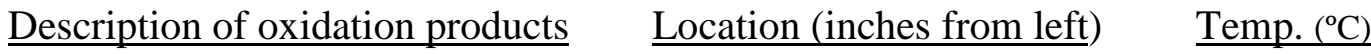

1. Localized white deposit on wall $12-14$ (This be due to the close positioning of the specimen to the wall of the reaction tube or to a localized cold spot in the wall of the reaction tube.)

\section{Deposition chamber}

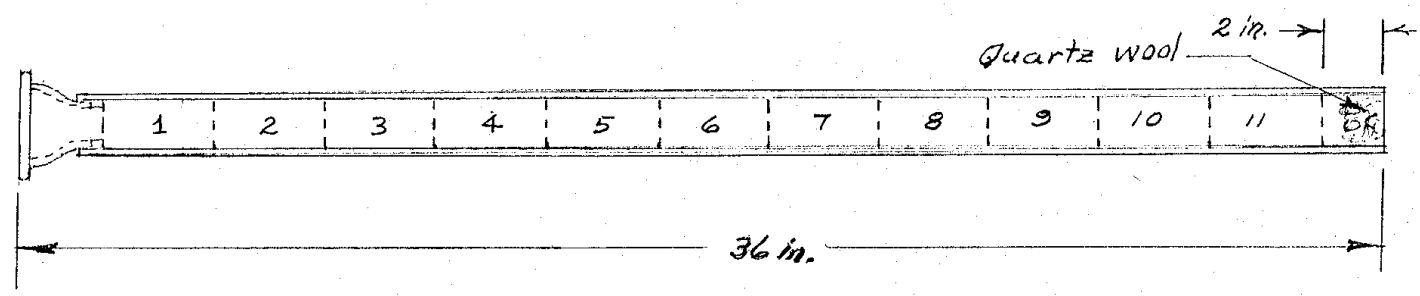

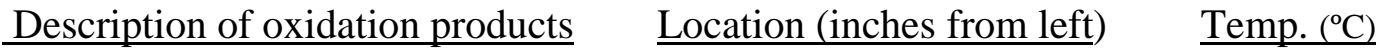

1. Start of light white deposit

2. Light, white deposit

3. Heavier white, smokey deposit

4. Clearer region, less deposit

5. Blue-grey deposit in front of quartz wool

6. Back of quartz wool is still white
12.5

$12.5-15.5$

$15.5-27.5$

$27.5-34$

$34-35$

$35-36$ 


\section{Description of Oxidation Products from TZM _}

Test temperature $\left({ }^{\circ} \mathrm{C}\right) \_\underline{600} \quad$ Time $(\mathrm{h}) \_\underline{24} \quad$ Flow rate $(\mathrm{lpm}) \_\underline{1}$

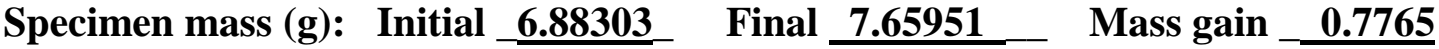

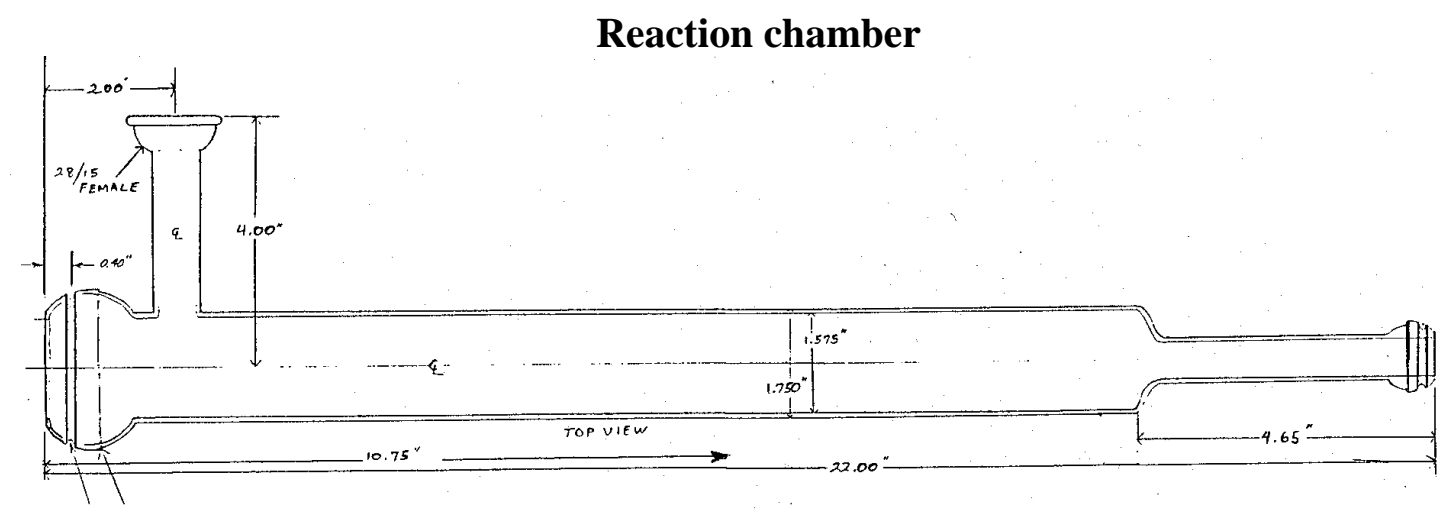

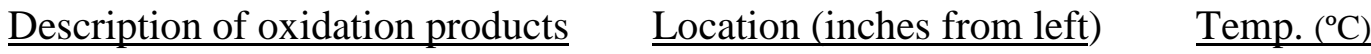

1. Nothing apparent in the reaction chamber.

2.

3.

4.

\section{Deposition chamber}

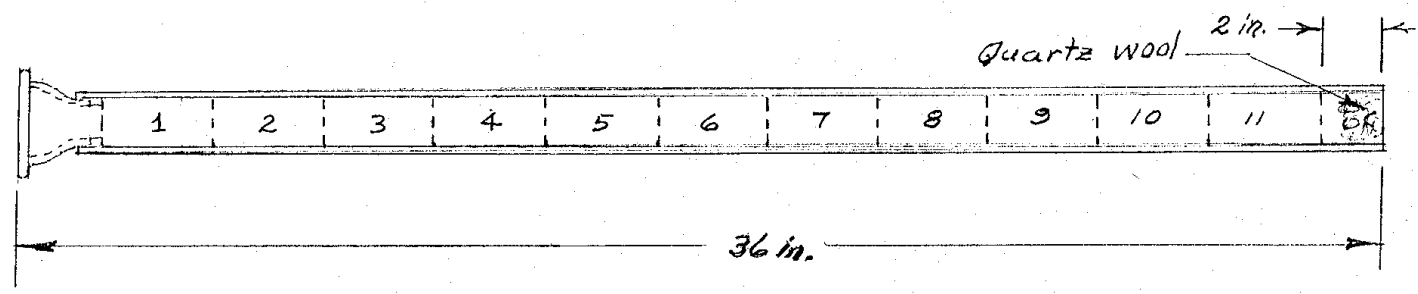

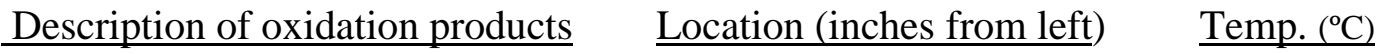

1. Clear, nothing present

2. Sporadic small crystals with small particles

3. Smoky deposit, i.e., small particles

4. White, to smoky, to light blue deposits

5. Clear

6. Quartz wool is blue in front and white in back
0 to 10

10 to 11

11 to 13

13 to 21.5

21.5 to 34 


\section{Description of Oxidation Products from TZM _}

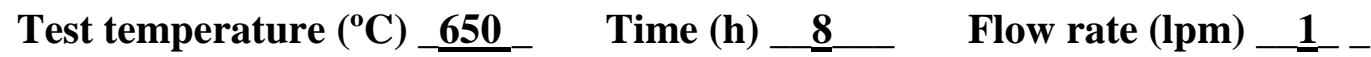
Specimen mass (g): Initial_

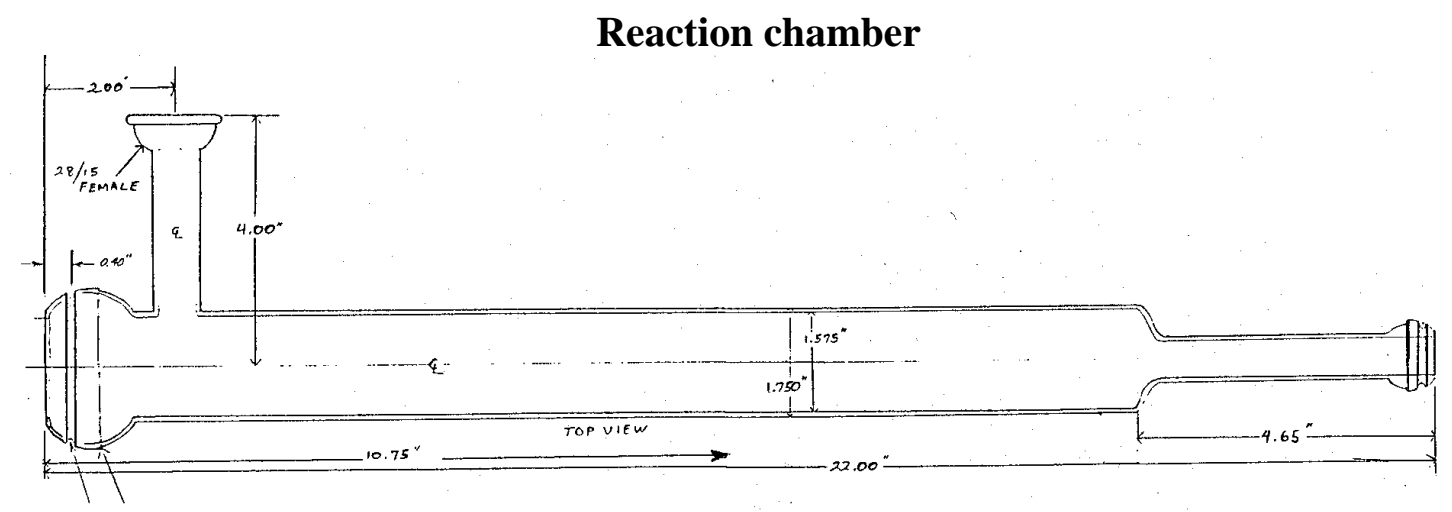

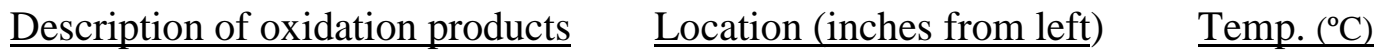

1. clear, nothing in the reaction chamber.

2.

3.

4.

Deposition chamber

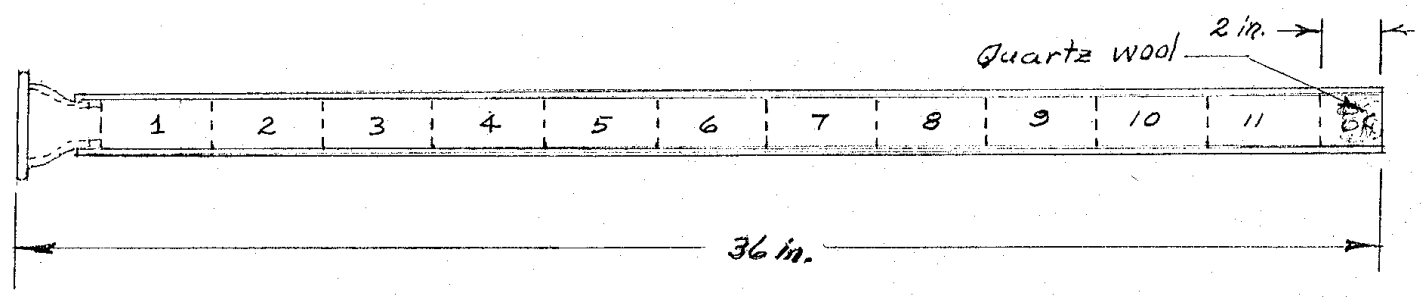

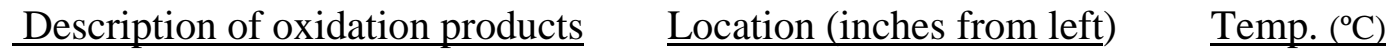

1. Clear through first three inserts. 0 to 10.25

2. Small crystals 11 to 12

3. Heavy, white smoky deposit. 12 to 14.5

4. Medium white smoky deposit. 14.5 to 16.5

5. Clearing (no evidence of deposit) 17

6. Quartz wool is very blue in front, clear (white) in back. 


\section{Description of Oxidation Products from TZM $\_\underline{4}$}

Test temperature $\left({ }^{\circ} \mathrm{C}\right) \_700 \quad$ Time $(\mathrm{h}) \_\underline{2} \quad$ Flow rate (lpm) $\_\underline{0.010}$ Specimen mass (g): Initial _ 6.1262 Final $\underline{6.1887}$ Mass gain $\underline{\mathbf{0 . 0 6 2 5}}$

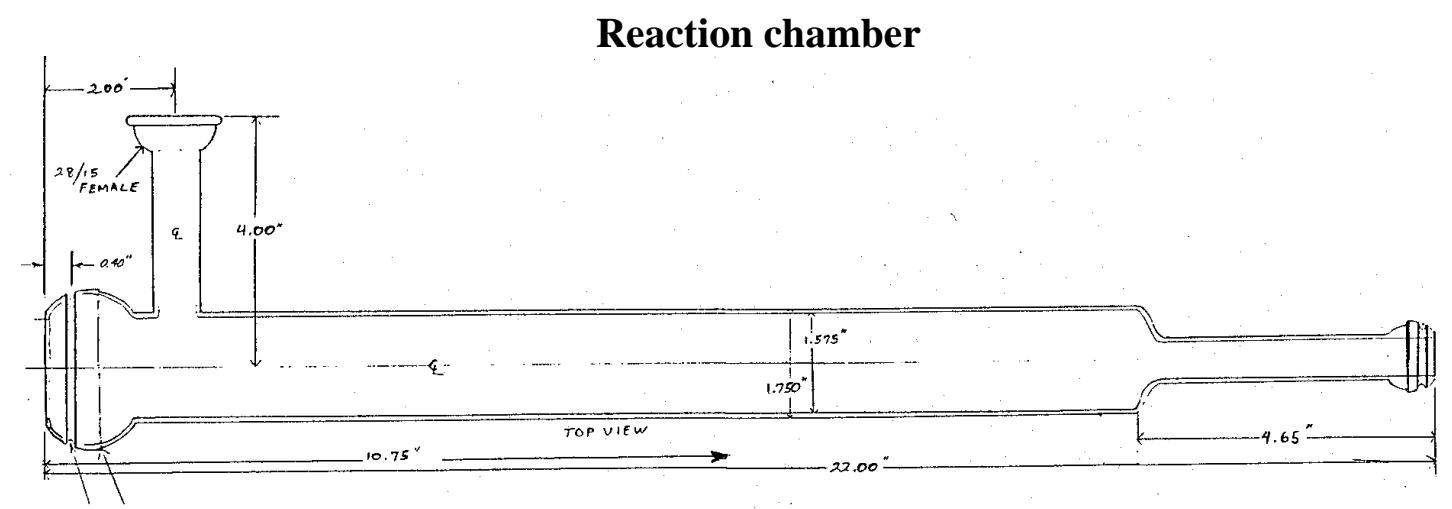

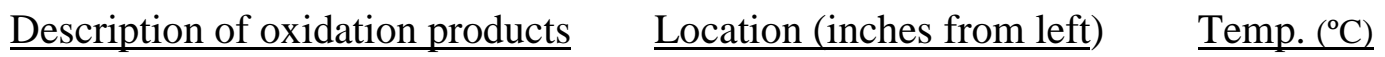

1. Clear except for some silvery, flat ribbon-like crystals near outlet. $\quad 18.5$ to 23

2.

3.

4.

Deposition chamber

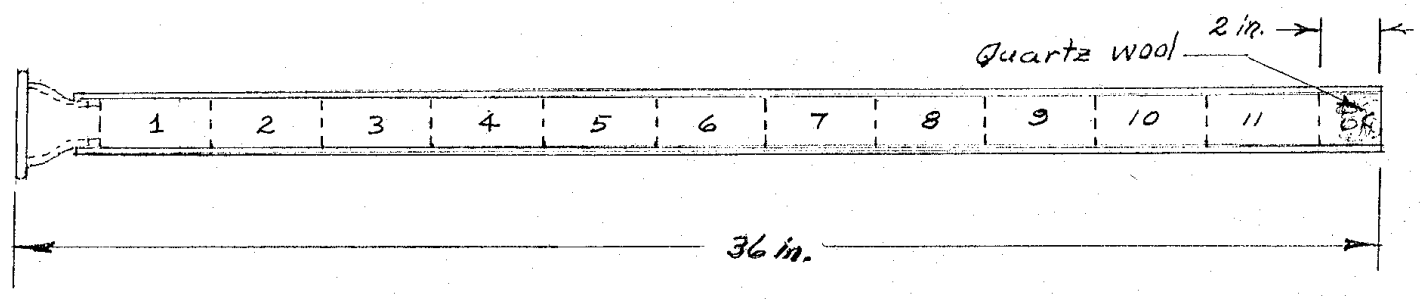

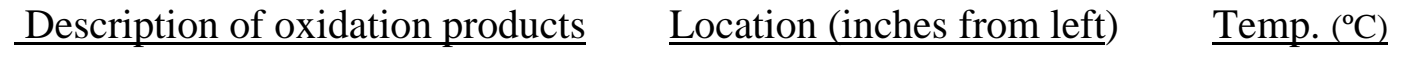

1. No apparent deposit in collection tube, inserts, or Q.W. filter.

2.

3.

4.

5.

6. 


\section{Description of Oxidation Products from TZM _}

Test temperature $\left({ }^{\circ} \mathrm{C}\right) \quad 700$ Time (h) $\_-8 \quad$ Flow rate (lpm) $\_$0.01 Specimen mass (g): Initial__13.4955 Final $\underline{\mathbf{1 3 . 7 4 8 5}}$ Mass gain $\underline{\mathbf{0 . 2 5 3 0}}$

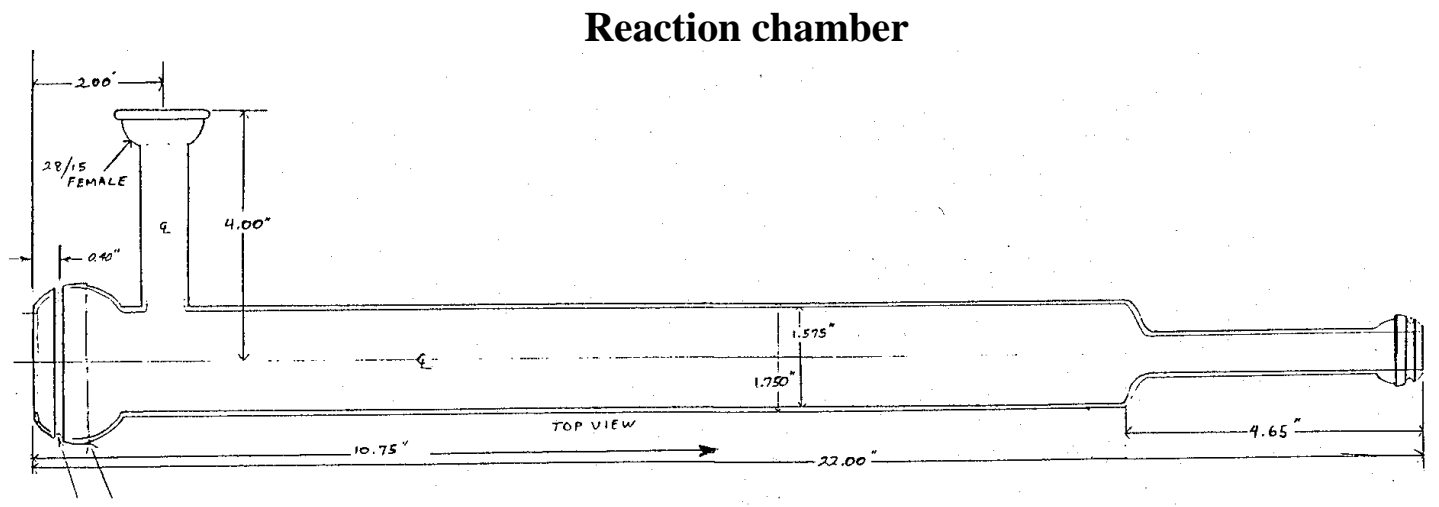

Description of oxidation products $\quad$ Location (inches from left) $\quad \underline{\text { Temp. }\left({ }^{\circ} \mathrm{C}\right)}$

1. Smoky deposit from 0 to 2.5 in., The cap has some smoky, white deposit.

2. Silvery crystals to ribbon-like needles 2.5 to 3.5

3. Thinly, distributed, very thin ribbon-like crystals 13.5 to 18.5

The crystals irradiant (showing green, blue, red or transparent depending upon angle of reflection).

\section{Deposition chamber}

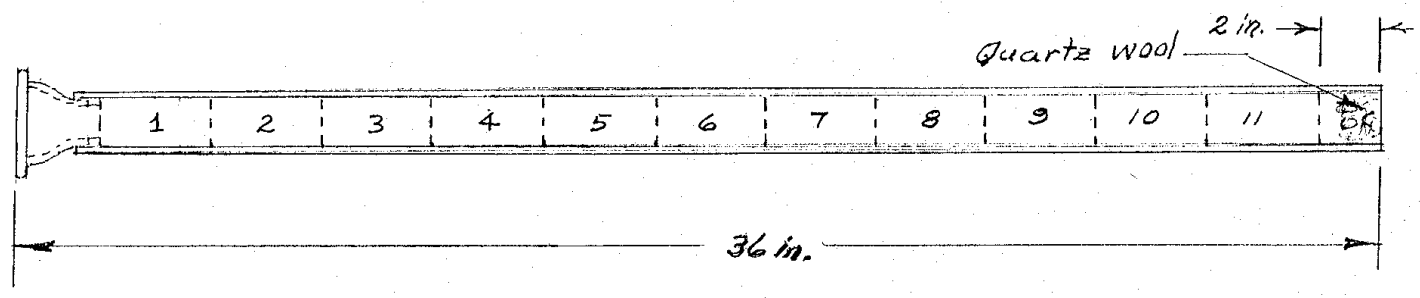

Description of oxidation products

1. Few, thin ribbon-like crystals.

2. Medium to small crystals

3. Light blue to smoky, thin deposit

4. Regions of light smoky blue deposits

5. Nothing apparent on the quartz wool
Location (inches from left)

Temp. $\left({ }^{\circ} \mathrm{C}\right)$
6 to 12

12 to 13.25

13.25 to 16

18.5 to 31 . 


\section{Description of Oxidation Products from TZM _ 5}

Test temperature $\left({ }^{\circ} \mathrm{C}\right) \quad 700$ Time (h) Specimen mass (g): Initial 6.7467 Final

\section{Reaction chamber}

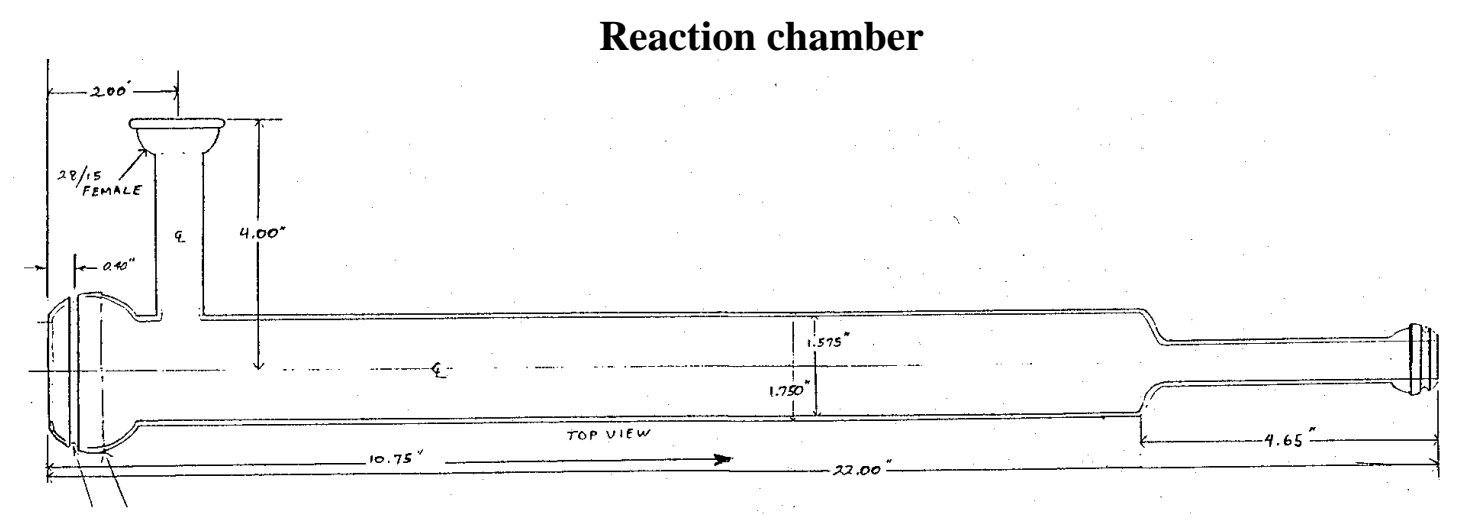

Flow rate $(\mathrm{lpm}) \_\underline{0.05} \mathrm{lpm}$

6.7988 Mass gain $\mathbf{0 . 0 5 2 1}$

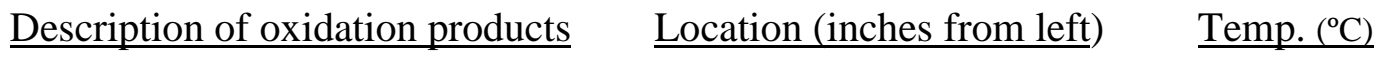

1. Small silvery needle-like crystals, widely spaced $\quad 18.5$ to 19.5

2. Very large crystals ( $1 / 8$ to $1 / 2$ in. long) 19.5 to 20.5

3.

4.

Deposition chamber

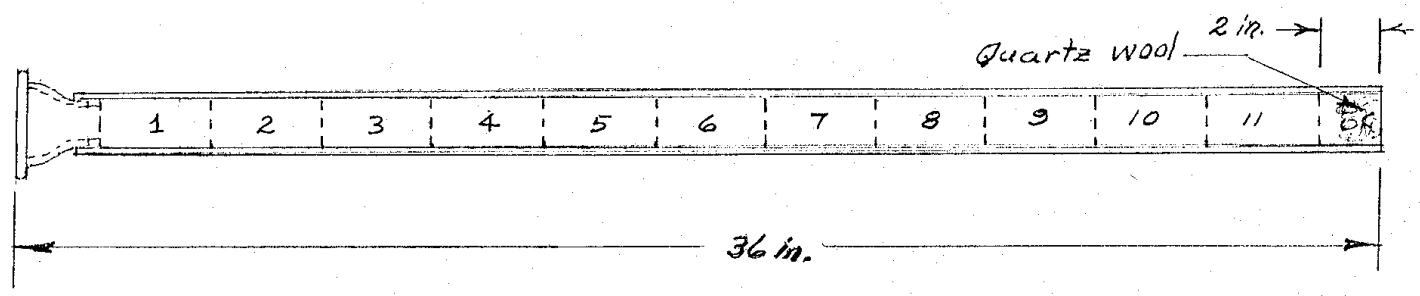

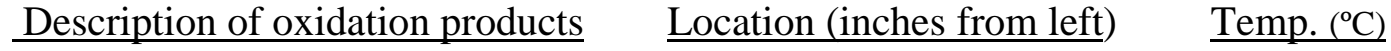

1. Few speck-size crystals, widely spaced. $\quad 0$ to 1

2. Mostly clear

0 to 12

3. Small crystals, widely spaced

10.75 to 12.25

4. Clusters of very small particles.

11.75 to 12.25

5. Particles become smaller and disappear.

12.25 to 13

6. Clear thereafter.

13 to 36 


\section{Description of Oxidation Products from TZM _ $\underline{18}$}

Test temperature $\left({ }^{\circ} \mathrm{C}\right) \_-700 \quad$ Time (h) $\_\_$_ $\quad$ Flow rate (lpm) $\_0.05$ Specimen mass (g): Initial__13.5565

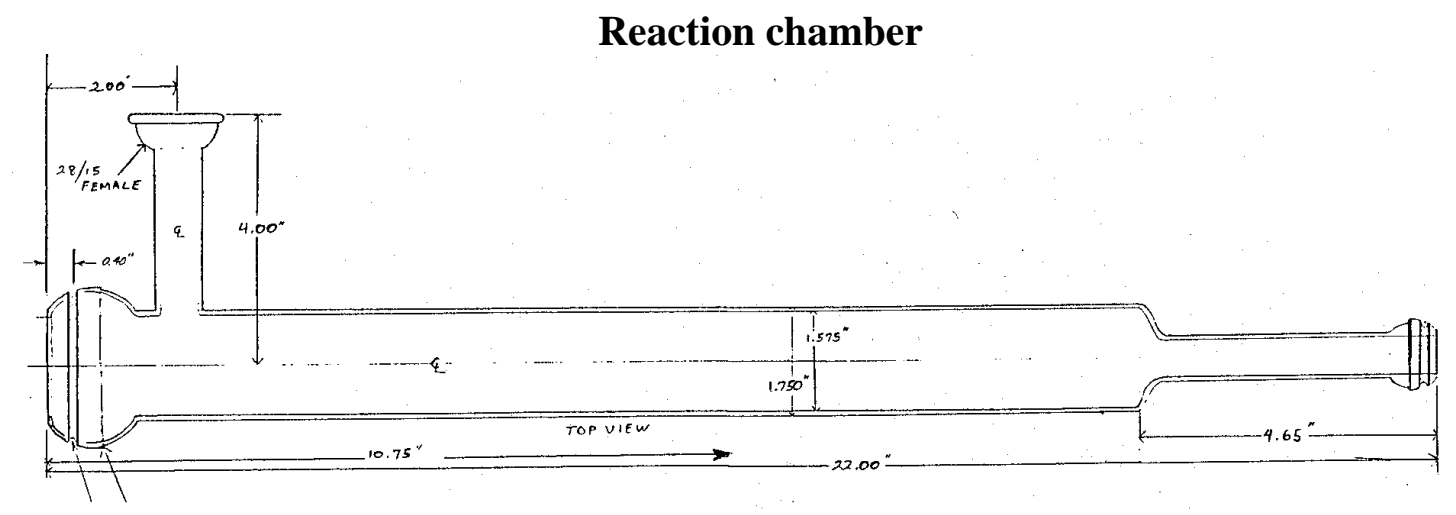

Description of oxidation products $\quad$ Location (inches from left) $\quad \underline{\text { Temp. }\left({ }^{\circ} \mathrm{C}\right)}$

1. There may be some slight haze on walls

2. Distinct needle-like crystals have formed

3. Heavier deposit of crystals.

4. Smaller less needle-like crystals
9.75 to 12

start at@13.5

16 to 17.5 (end of large section)

17.5 to 22

\section{Deposition chamber}

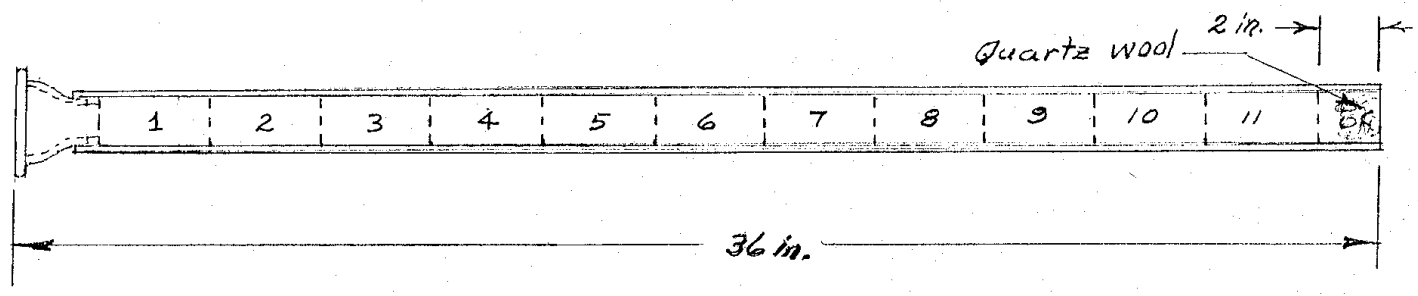

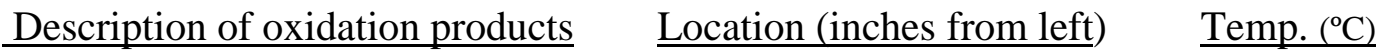

1. Very light whitish, smoky haze

2. Large ribbon-like crystals (some 0.5 in.)

3. Heavier deposit which extends across I.D.

4. Smaller crystals

5. Just haze on wall

6. Fewer, small crystals on wall

7. Heavy collection of ribbon-like crystals in front 33.5 to 34.5 quartz wool filter

8. No indication on any color on quartz wool.
0 to 36

9 to 11.5

11.5 to 12.5

12.5 to 14.5

14.5 to 27

27 to 33.5 
Test temperature $\left({ }^{\circ} \mathrm{C}\right) \quad \underline{\mathbf{7 0 0}} \quad$ Time $(\mathrm{h}) \_\underline{2} \quad$ Flow rate (lpm)

Specimen mass (g): Initial __ $\underline{\mathbf{6 . 7 1 8 5 7}}$ Final _.

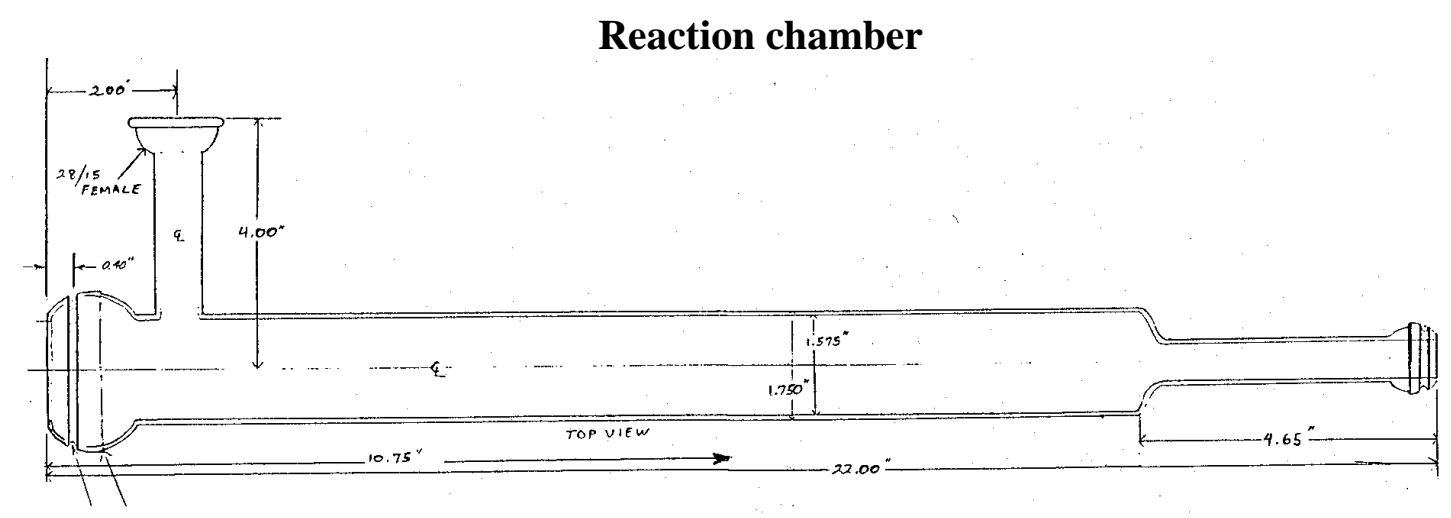

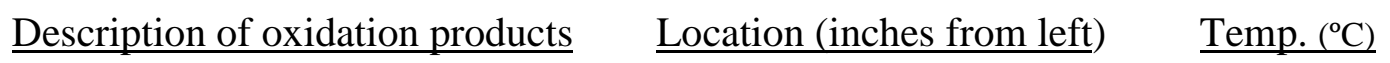

1. Large to medium shiny, silver, flat sliver-like crystals sporadically attached: 8 to 14 .

2. Crystals on top of tube. 9 to 13

3. Crystals on bottom of tube. 12 to 14.5

4. Smokey deposit on top of tube. 12 to 14

Deposition chamber

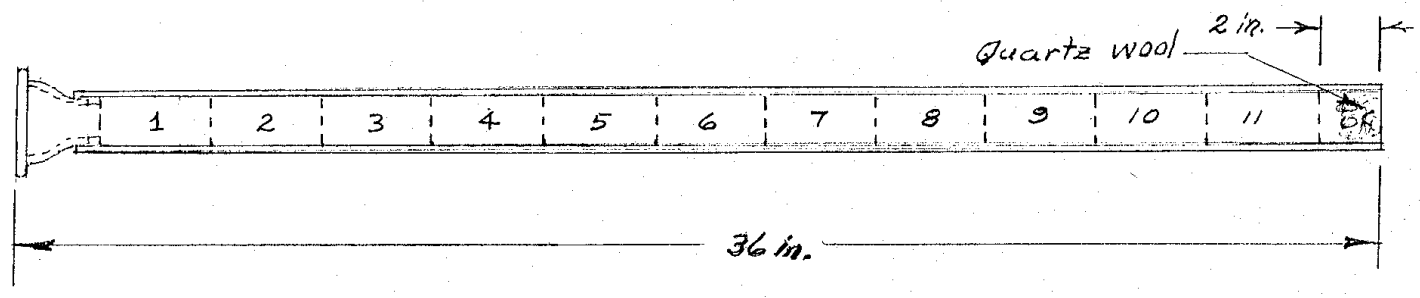

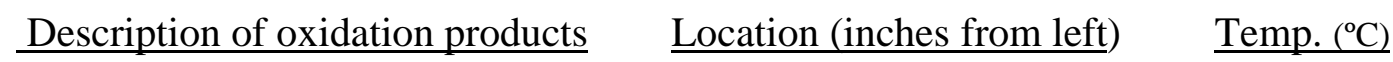

1. Clear

2. Silvery sliver-like crystals

3. Smoky deposit on wall

4. Smaller yellowish needle-like crystals

5. White smoky deposit: heavy 12.5 to 16 , Becomes light to clear at about 16 inches.

6. Large silver crystals at 34 to 36 likely dislodged during transport.

7. None to barely detectable deposit in quartz wool.
0 to 10

10 to 13.5

13.5 to 17

11 to 13 


\section{Description of Oxidation Products from TZM _}

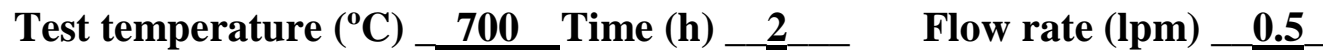
Specimen mass (g): Initial _

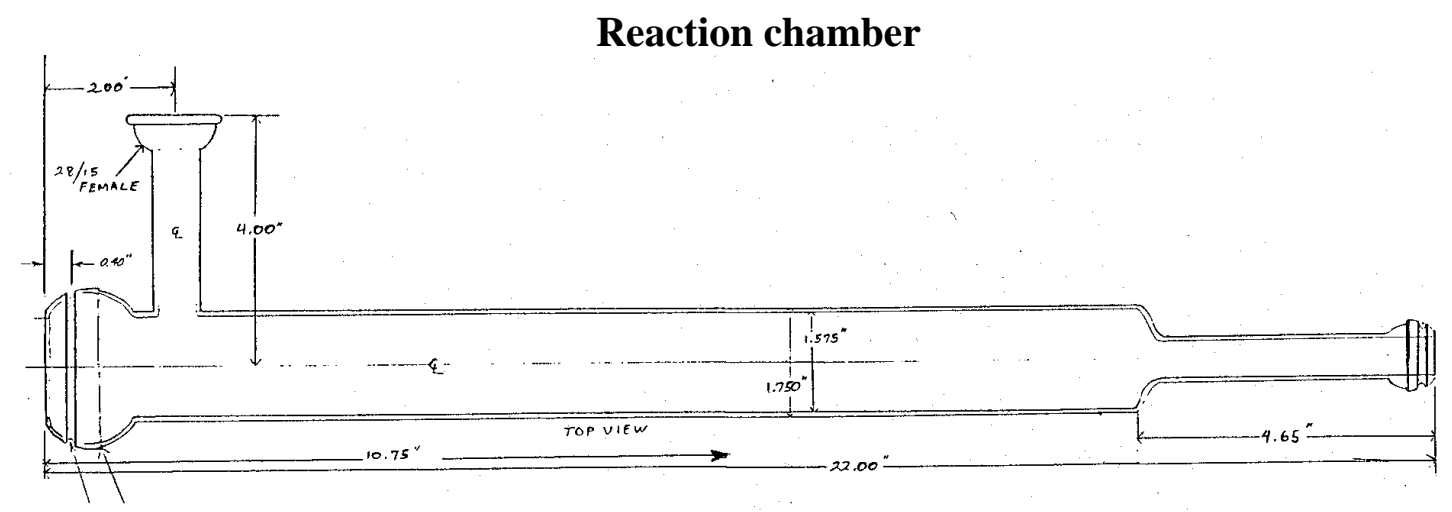

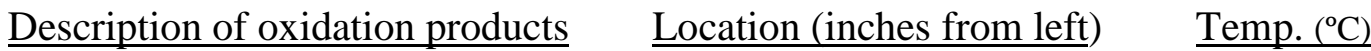

1. Clear over most of the chamber.

2. Silvery crystals on the wall Last 2 inches

3. The amount of crystals are less than those observed for the test with $0.05 \mathrm{lpm}$ flow. 4.

\section{Deposition chamber}

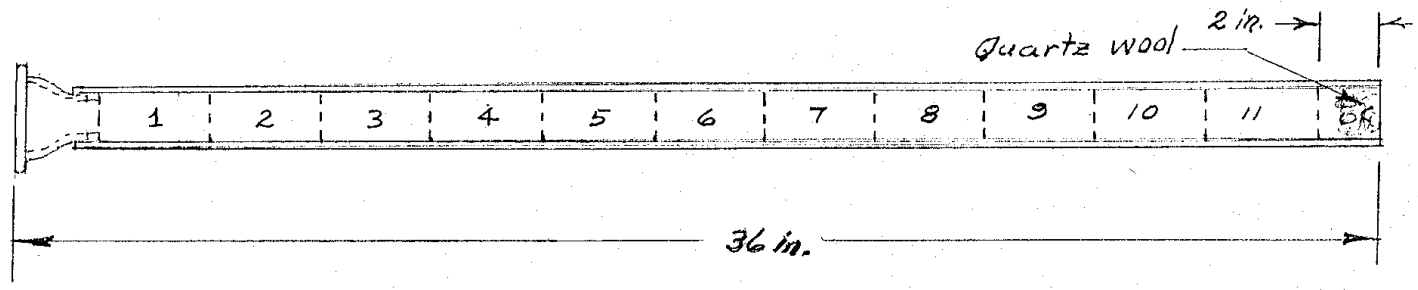

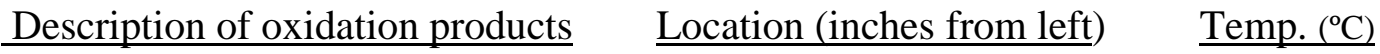

1. Very small crystals on first insert.

2. Clear

3. Larger silvery crystals.

4. White deposit.

5. Very light blue deposit

6. Heavier blue deposit

7. Quartz wool is blue in front, white in back.
2 to 2.5

2.5 to 10

10 to 12.5

12.5 to 17

17 to 31.5

31.5 to 34.5

34.5 to 36. 


\section{Description of Oxidation Products from TZM _ $\underline{12}$}

\begin{tabular}{|c|c|c|}
\hline Test temperature $\left({ }^{\circ} \mathrm{C}\right)$ & Time (h) & Flow rate $(\mathrm{lpm}) \_1$ \\
\hline
\end{tabular}

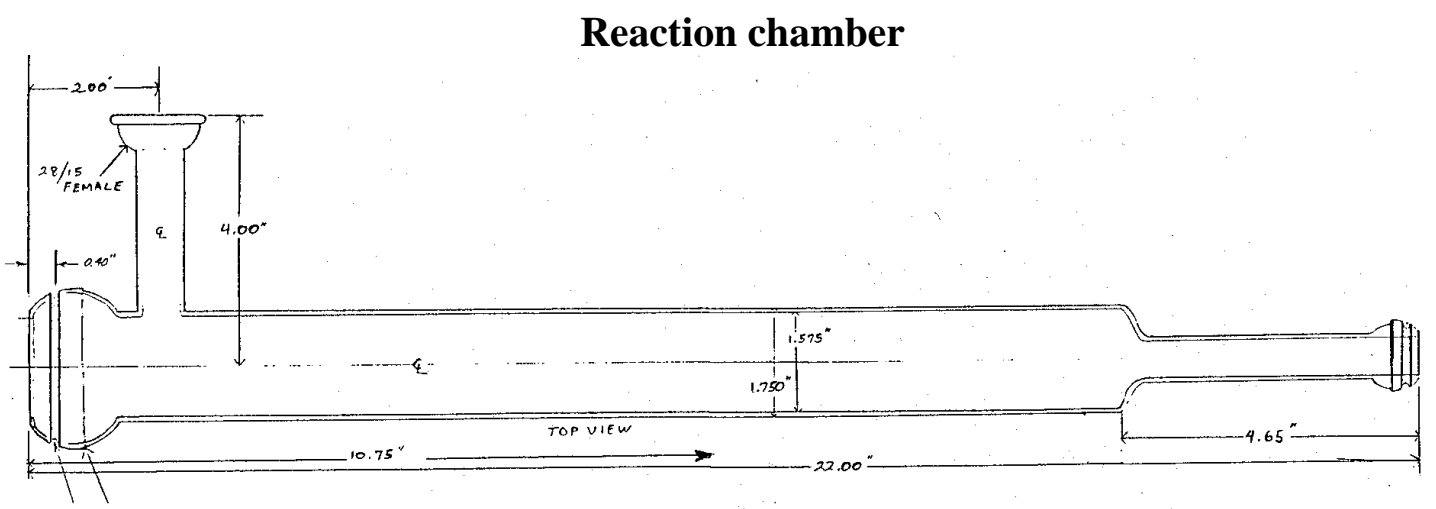

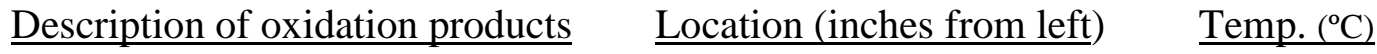

1. There is only a few small clear crystals at one location likely from when the specimen contacted the surface during removal.

\section{Deposition chamber}

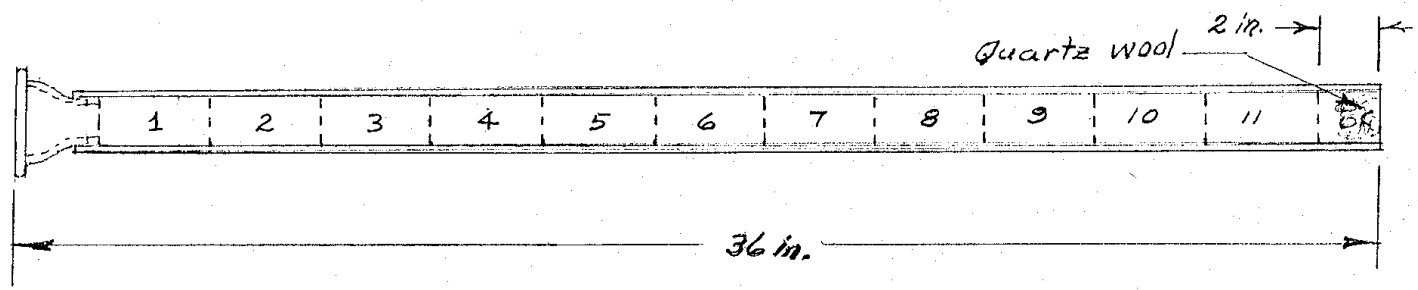

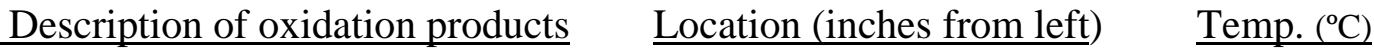

1. Formation of clear crystal start

2. Crystal become larger

4. Crystals become smaller

5. White to smoke color deposit

6. Very light haze

7. Clear region

8. Hazy deposit increases (bluish hue)

9. Quartz wool is blue in front, white in back
9.75 inches

9.75 to 10.75

10.75 to 12.25

12.25 to 16.25

16.25 to 23.5

23.5 to 29

29 to 34

34 to 36 


\section{Description of Oxidation Products from TZM _ 9}

Test temperature $\left({ }^{\circ} \mathrm{C}\right) \_\underline{700} \_$Time $(\mathrm{h}) \_\underline{2} \quad$ Flow rate $(\mathrm{lpm}) \quad \underline{2.5}$ Specimen mass (g): Initial__6.52977 - Final _ 6.52907_ Mass loss _

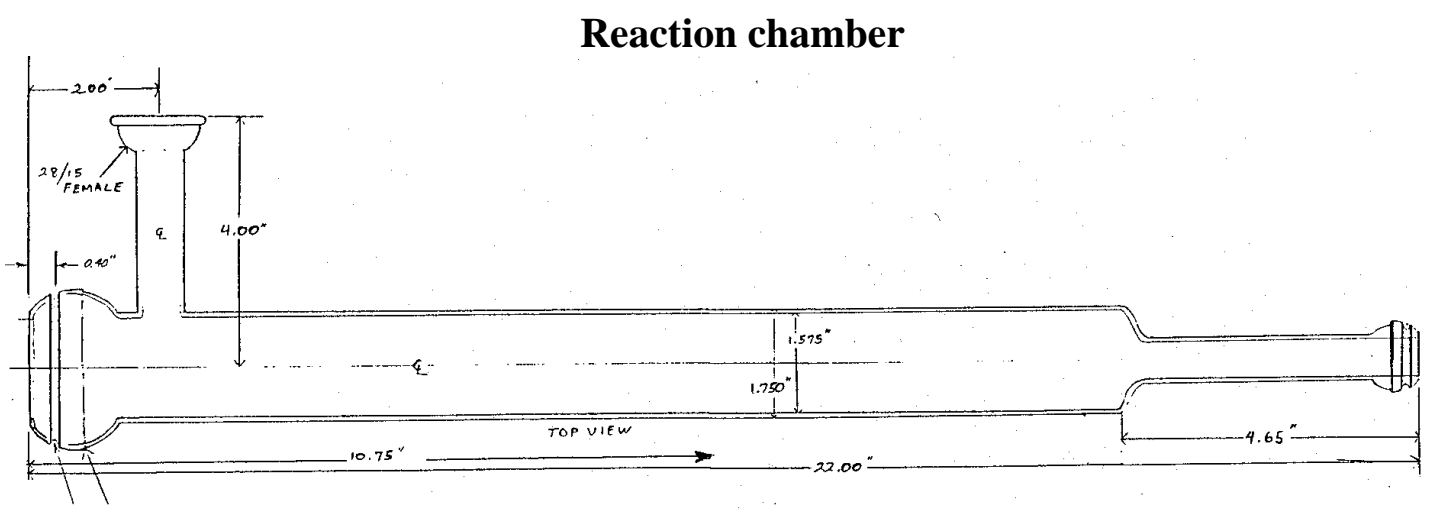

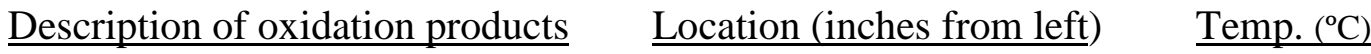

1. No evidence of any deposit in the reaction chamber.

2.

3.

4.

\section{Deposition chamber}

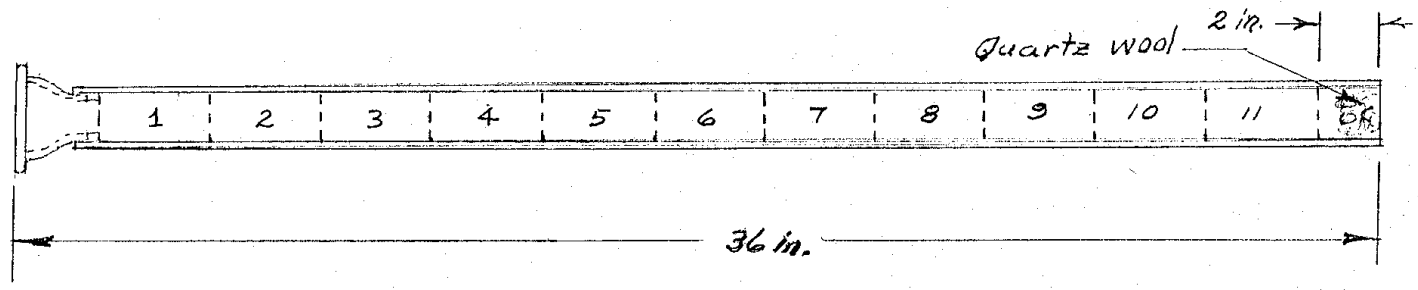

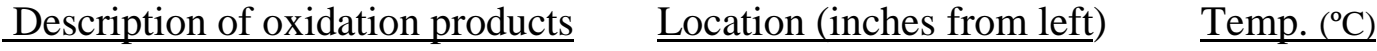

1. Clear, except for a few small needle-like crystals. $\quad 0$ to 10.5

2. Small crystal, heavier deposition.

10.5 to 11.5

3. White deposit on walls.

11.5 to 17

4. Smokey deposit

17 to 33.5

5. Blue deposit

33.5 to 34

6. Blue deposit in front half, white at end of quartz wool.

34 to 36 


\section{Description of Oxidation Products from TZM $\_\underline{3}$}

Test temperature $\left({ }^{\circ} \mathrm{C}\right) \quad-\quad 750 \quad$ Time (h) $\quad \ldots \quad \underline{1}$ Flow rate (lpm) Specimen mass (g): Initial_ $\underline{6.48253}$ Final $\quad 6.1071$ Mass loss $\underline{0.3754}$

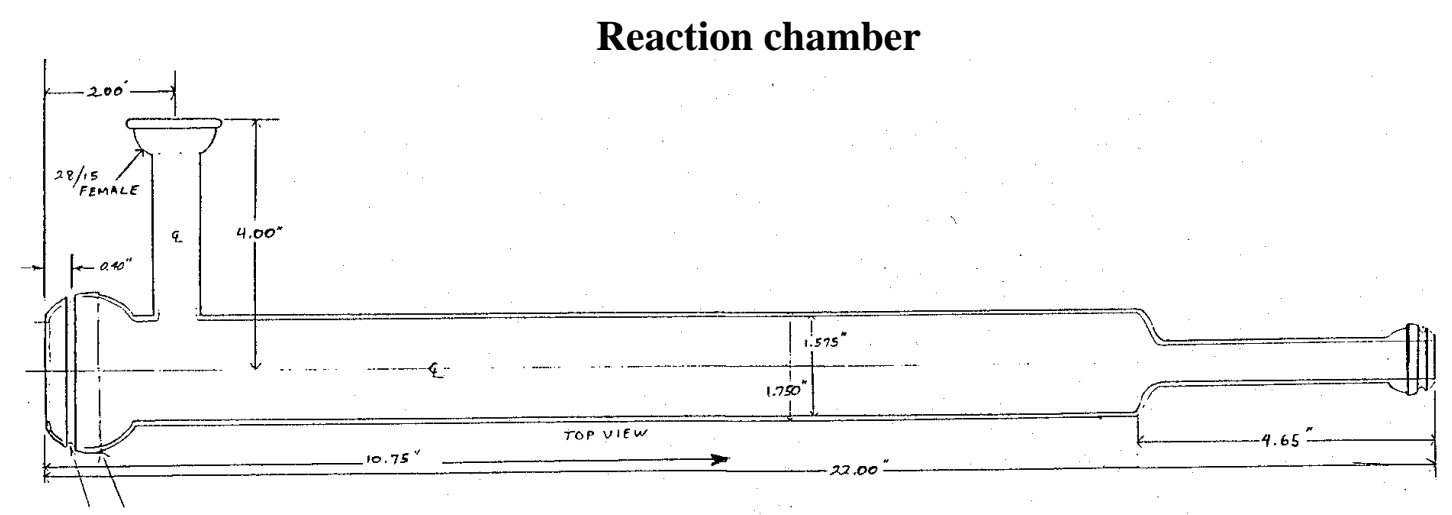

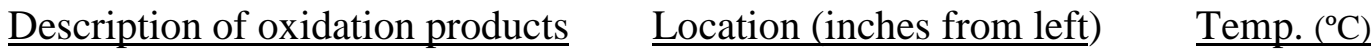

1. Silvery flat needle-like crystals (1/4-in.) at exit. 20.5 to 23

Deposition chamber

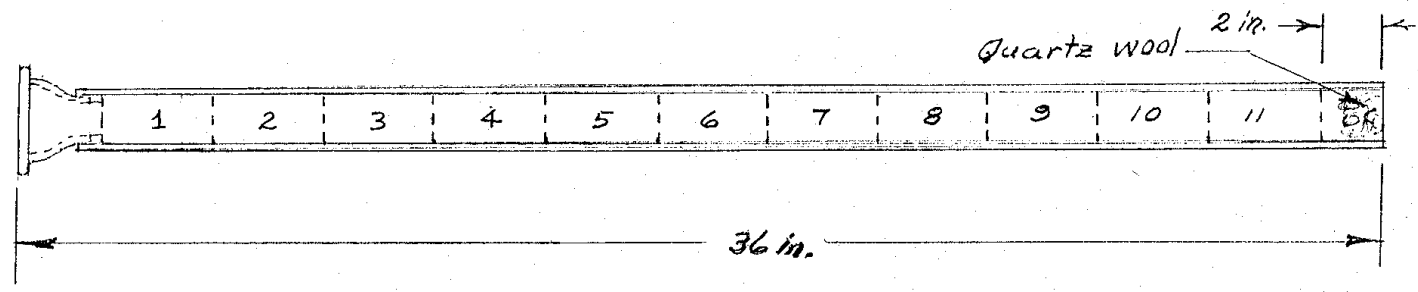

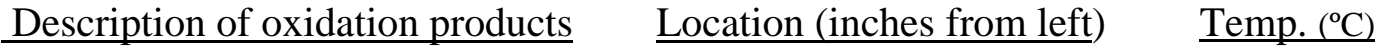

1. Silvery needle-like crystals

2. Clear.

3. Large greenish crystals extending across tube

4. Med. and small crystals, heavy conc.

5. Small crystals with crystalline particles, i.e., white smoky deposit.

6. Heavy white deposit, crystals becoming yellowish

7. White smoky deposit with greenish streaks.

8. Yellow-greenish smoky deposit

9. Greenish smoky deposit becomes heavier.

10. Heavy greenish deposit in quartz wool, the end is still white.
0 to 1

1 to 10

10 to 11.5

11 to 12.25

12.25 to 14

14 to 16

16 to 25

25 to 31

34.25

34.25 to 36 


\section{Description of Oxidation Products from TZM $\_\underline{2}$}

Test temperature $\left({ }^{\circ} \mathrm{C}\right) \_$800 $\quad$ Time (h) $\_1$ Flow rate (lpm) $\_1$

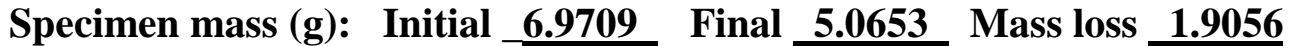
Final weight includes $3.6498 \mathrm{~g}$ from specimen plus 1.4152 from molten oxide.

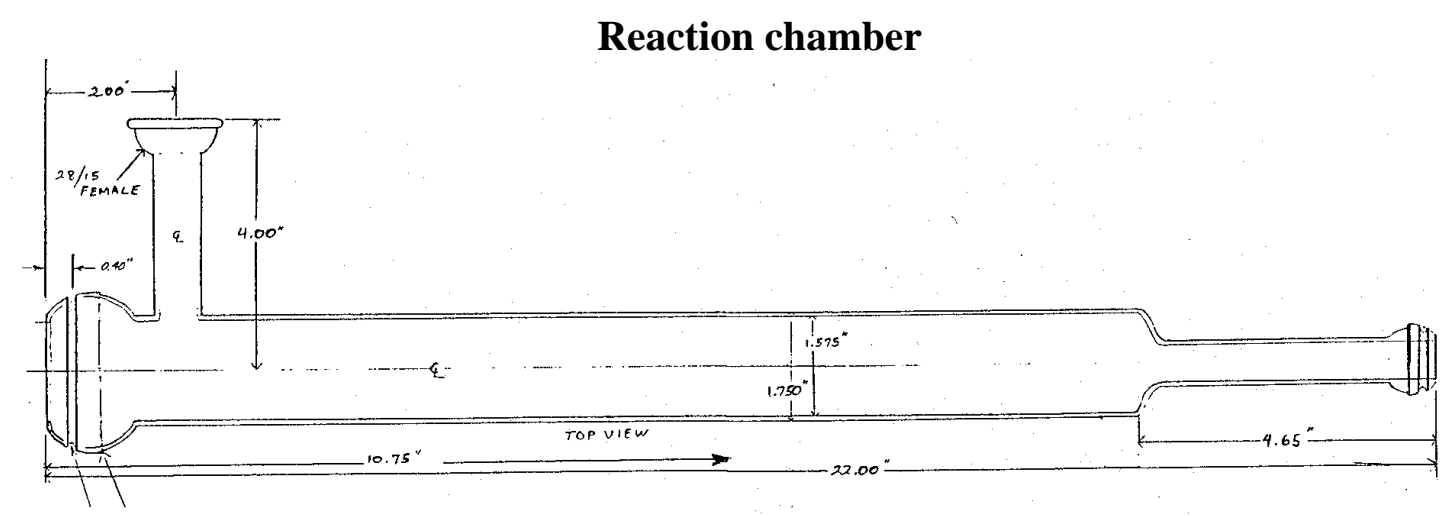

Description of oxidation products $\quad$ Location (inches from left) $\quad \underline{\text { Temp. }\left({ }^{\circ} \mathrm{C}\right)}$

1. Two pieces of molten oxide (1.4152 g) $\quad 13.4$ to 17.5

2. Crystals changing from white, to yellow, to greenish 18.5 to 22

3. Larger greenish crystals appear to nearly block tube at outlet.

\section{Deposition chamber}

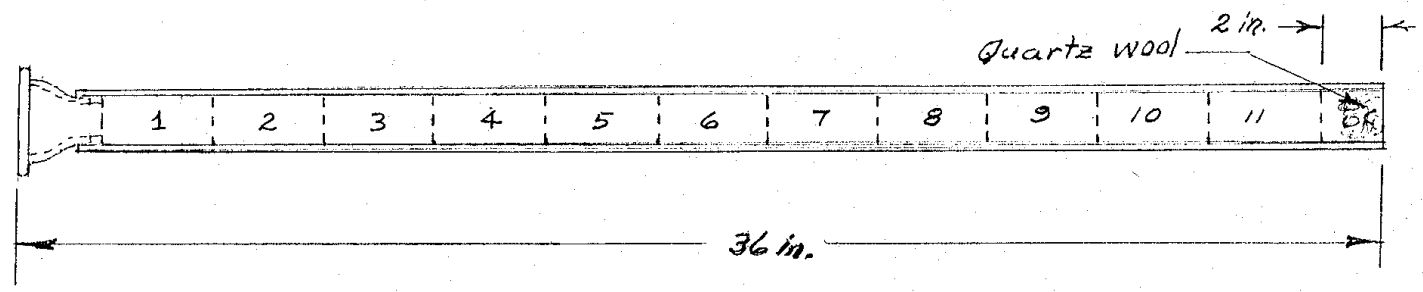

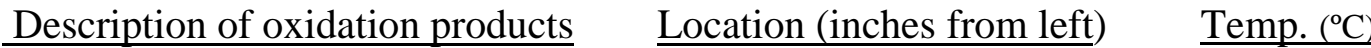

1. Clear.

2. Few, yellow (silver) crystals

3. Heavy yellow, greenish crystals extend across I.D.

4. Heavy white smoky deposit with some crystals

5. Deposit becomes yellow (or light greenish) again with some crystals

6. Heavy conc. of yellow-greenish crystals in front of quartz wool.

7. Heavy yellow-greenish deposit in front of quartz wool. (The back portion to the quartz wool is still white.)
0 to 11

11 to 14

14 to 16

16 to 20

20 to 34

34 to 35

35 to 36 


\section{APPENDIX B}

PROCEDURES FOR CLEANING THE MOLYBDENUM-BEARING TEST COMPONENTS AND PROCESSING THE SOLUTIONS FOR ICP-AES ANALYSES 
Processing and Analytical Procedures for Molybdenum -Bearing Glassware.

for

Molybdenum Oxidation Tests

IHRG\# IRC-99-740

Scope: This procedure describes chemically removing molybdenum oxidation products from quartz test components. The test components the reaction chamber, collection tube, quartz tube inserts, and quartz wool filters as described in IHRG \#IRC-99-740.

The following basic procedures will be used for all components (there will be only minor differences used to handle the various components).

1. Wash the component once or twice with $2.9 \mathrm{Molar}^{\mathrm{NH}} \mathrm{H}_{4} \mathrm{OH}$ solution.

2. Rinse with nanopure water.

3. Heat solutions in covered Teflon beakers on hot plate to drive off $\mathrm{NH}_{3}$.

Transfer solution to 100 -ml volumetric flask.

Add $5 \mathrm{ml}$ of concentrated nitric acid (Normality of 15.8).

Dilute to $100 \mathrm{ml}$ with nanopure water.

Analyze by ICP-AES.

The reaction chamber and 36-long collection tube will be sealed with Parafilm at on end. The $25 \mathrm{ml}$ of the $2.9 \mathrm{M} \mathrm{NH}_{4} \mathrm{OH}$ will then be added and the other end sealed with Parafilm. The component will then be manipulated to wash the inner surfaces. This solution will be transferred to a Teflon beaker and the process repeated with another batch of $2.9 \mathrm{M} \mathrm{NH}_{4} \mathrm{OH}$. The inside surfaces of the component will then be rinsed with nanopure water using a squirt bottle. The rinse water will be drained directly into the Teflon beaker. This rinsing process will be done at least twice. The solution collected in the Teflon beaker will be processes as indicated above.

There are two different sizes of quartz tube inserts: 1-in. long pieces and 3-in. long pieces. Molybdenum oxidation products will be cleaned from these pieces by rinsing them with of $2.9 \mathrm{M} \mathrm{NH}_{4} \mathrm{OH}$ solution dispensed from a squirt bottle. Approximately 50 $\mathrm{ml}$ will be used to rinse each segment directly into a Teflon beaker. Each segment will then be rinsed with about $30 \mathrm{ml}$ of nanopure water. The solution collected in the Teflon beaker will be processes as indicated above.

The quartz wool filter will be placed in a 50-ml plastic disposable beaker. It will be soaked in $25 \mathrm{ml}$ of the $2.9 \mathrm{M} \mathrm{NH}_{4} \mathrm{OH}$ solution overnight. The $25 \mathrm{ml}$ of solution will be transferred to a Teflon beaker. Another $25 \mathrm{ml}$ of $2.9 \mathrm{M} \mathrm{NH}_{4} \mathrm{OH}$ solution will be added to the quartz wool for a second soak (approx. 10 minutes). The quartz wool will then be rinse with $2.9 \mathrm{M} \mathrm{NH}_{4} \mathrm{OH}$ solution from a squirt bottle followed by a nanopure water rinse. All solutions will have been collected in the Teflon beaker which will be processes as indicated above. 


\title{
APPENDIX C
}

\author{
ICP-AES ANALYSES, \\ MASS FLUX CALCULATIONS, \\ MOLYBDENUM DISTRIBUTIONS, \\ TEMPERATURE PROFILES
}




\section{TZM14: Tested at $400^{\circ} \mathrm{C}$ for 24 hours (1000 sccm flow)}

\begin{tabular}{|c|c|c|c|c|}
\hline \multicolumn{5}{|c|}{ ICP-AES measurements for $100 \mathrm{ml}$ aloquits, except RXN Tube is $250 \mathrm{ml}$. } \\
\hline & & & & Mo 202.0 \\
\hline \multicolumn{3}{|c|}{ Calculated per EDF SA-17, i.e., 2 sigma (S.D.) for uncertainities } & & $========$ \\
\hline \multicolumn{3}{|c|}{ and 3 sigma (S.D.) for detection limits. } & & \\
\hline For Data analyzed & & $\%$ SD of Cal. Stds & sigma $\%$ & 3.300 \\
\hline on 6-21-99 & & SD of Blk Std & sigma prime $\mathrm{ug} / \mathrm{ml}$ & 0.005 \\
\hline TZM14 & $400 \mathrm{C} / 24 \mathrm{~h}$ & & $\mathrm{~F} 1, \mathrm{ug} / \mathrm{ml}$ & -0.008 \\
\hline Tested 6-2-99 & air & & $\mathrm{F} 2, \mathrm{ug} / \mathrm{ml}$ & -0.006 \\
\hline \multirow[t]{4}{*}{ time } & 24.000 & & $\mathrm{~F} 3, \mathrm{ug} / \mathrm{ml}$ & -0.006 \\
\hline & & & $\mathrm{F} 4, \mathrm{ug} / \mathrm{ml}$ & -0.008 \\
\hline & & & $\mathrm{F} 5, \mathrm{ug} / \mathrm{ml}$ & -0.007 \\
\hline & & & F6, ug/ml & -0.008 \\
\hline \multirow[t]{6}{*}{ area,cm2 } & 10.34500 & & F7, ug/ml & -0.011 \\
\hline & & & $\mathrm{F} 8, \mathrm{ug} / \mathrm{ml}$ & -0.013 \\
\hline & & & $\mathrm{F} 9, \mathrm{ug} / \mathrm{ml}$ & -0.013 \\
\hline & & & F10,ug/ml & -0.012 \\
\hline & & & $\mathrm{F} 11, \mathrm{ug} / \mathrm{ml}$ & -0.013 \\
\hline & & & QW,ug/ml & -0.010 \\
\hline \multirow[t]{5}{*}{ Flux set by EMFV. } & & & C.T.,ug/ml & 0.000 \\
\hline & & & RXN T,ug/ml & -0.001 \\
\hline & & & subtotal, ug & -11.750 \\
\hline & & & $(+/-)$ ug & 0.228 \\
\hline & & & Blk sub, ug & -8.400 \\
\hline \multicolumn{2}{|c|}{ "IF" statement compares Total } & & $(+/-)$ ug & 3.742 \\
\hline \multicolumn{3}{|c|}{ with $3 * S D(u g)$, and all "FX" \& "Component" } & Total, ug & -3.350 \\
\hline \multicolumn{2}{|c|}{ measurements with $3 * \mathrm{SD}(\mathrm{ug} / \mathrm{ml})$. } & & $(+/-)$ ug of Sum & 3.749 \\
\hline \multicolumn{5}{|c|}{ Total is selected if any of the } \\
\hline \multicolumn{3}{|c|}{ "FX",QW,CT or RXN T measurements are } & DL (3*SD),ug/ml & 0.015 \\
\hline \multicolumn{2}{|c|}{ greater than $3 * \mathrm{SD}(\mathrm{ug} / \mathrm{ml})$} & & DL $(3 * S D)$, ug & 1.500 \\
\hline & & Detection Limit ( EMFV) & $\mathrm{g} / \mathrm{m} 2-\mathrm{h}$ & $6.04 \mathrm{E}-05$ \\
\hline & & Total correct for DL (IF statement), ug & & 1.500 \\
\hline & & Calculated from Total & Mass Flux, g/m2-h & $-1.35 \mathrm{E}-04$ \\
\hline & & Calc. from 'IF" statement & Mass Flux, g/m2-h & $6.04 \mathrm{E}-05$ \\
\hline & & & $\pm \mathrm{g} / \mathrm{m} 2-\mathrm{h}$ & $1.51 \mathrm{E}-04$ \\
\hline & & & $\pm \%$ & 249.91 \\
\hline & & & & \\
\hline
\end{tabular}




\section{TZM15: Tested at $500^{\circ} \mathrm{C}$ for 24 hours (1000 sccm flow)}

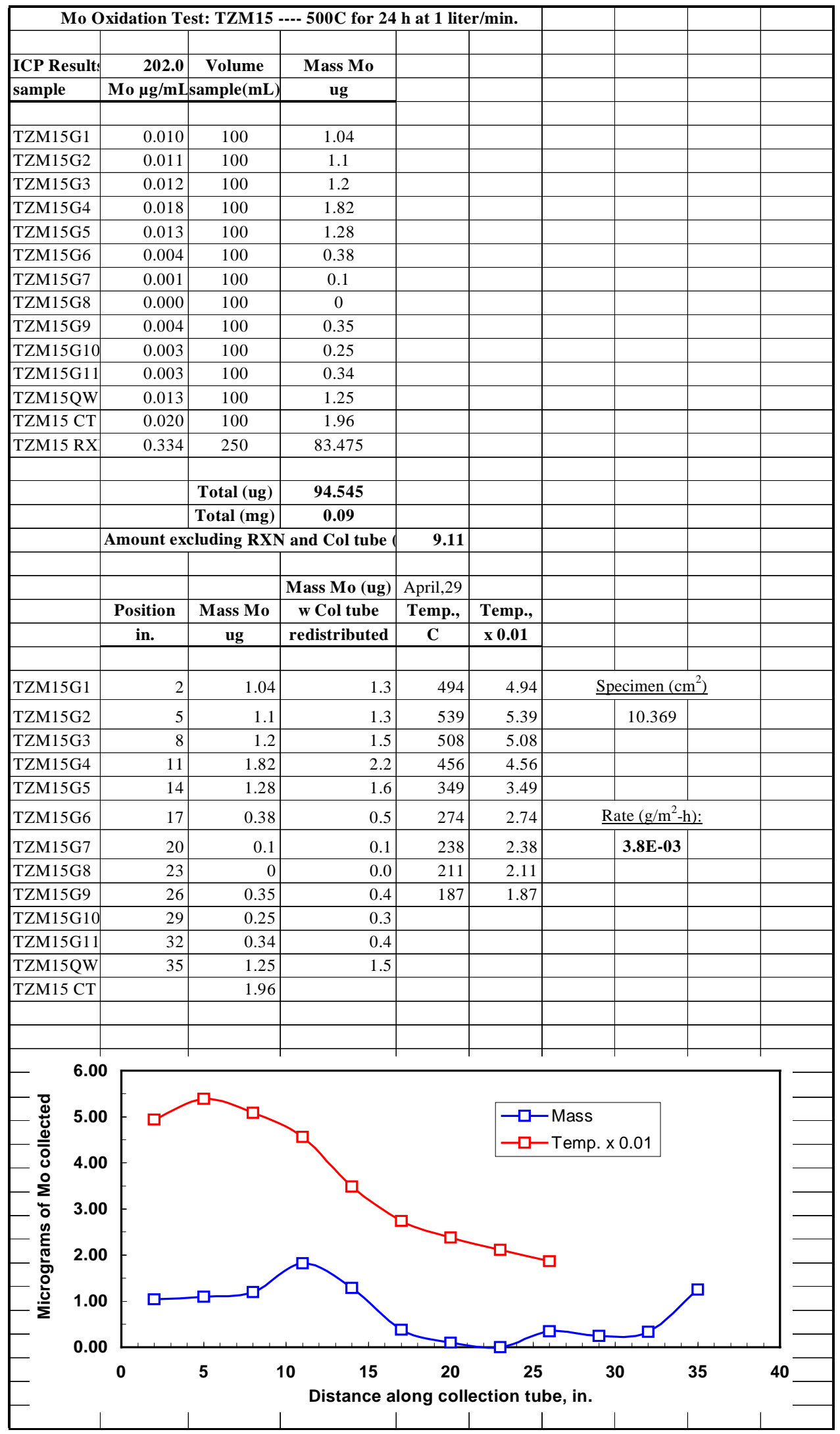




\section{TZM15: Tested at $500^{\circ} \mathrm{C}$ for 24 hours (1000 sccm flow)}

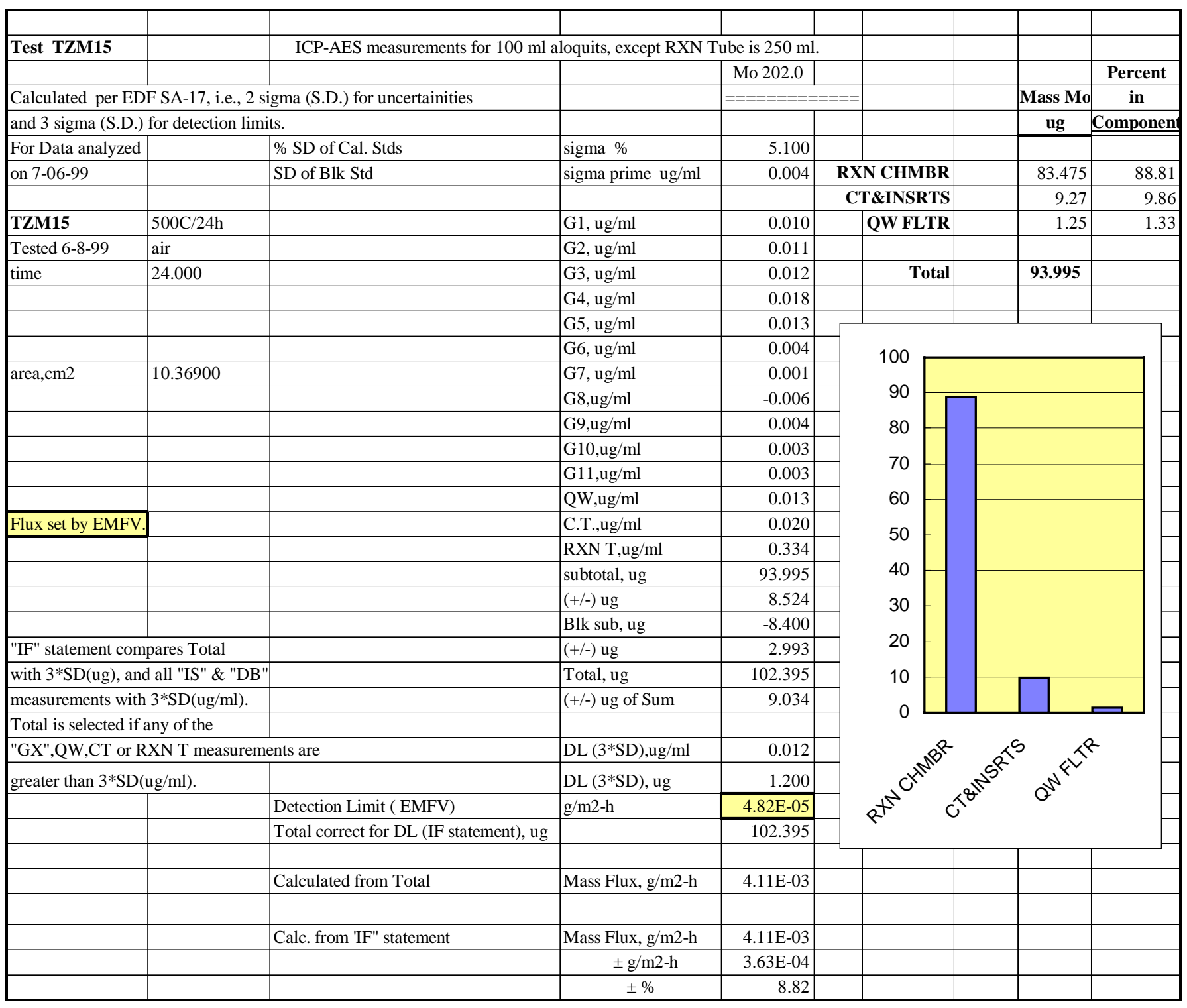


TZM1: Tested at $500^{\circ} \mathrm{C}$ for 24 hours $(1000 \mathrm{sccm}$ flow $)$

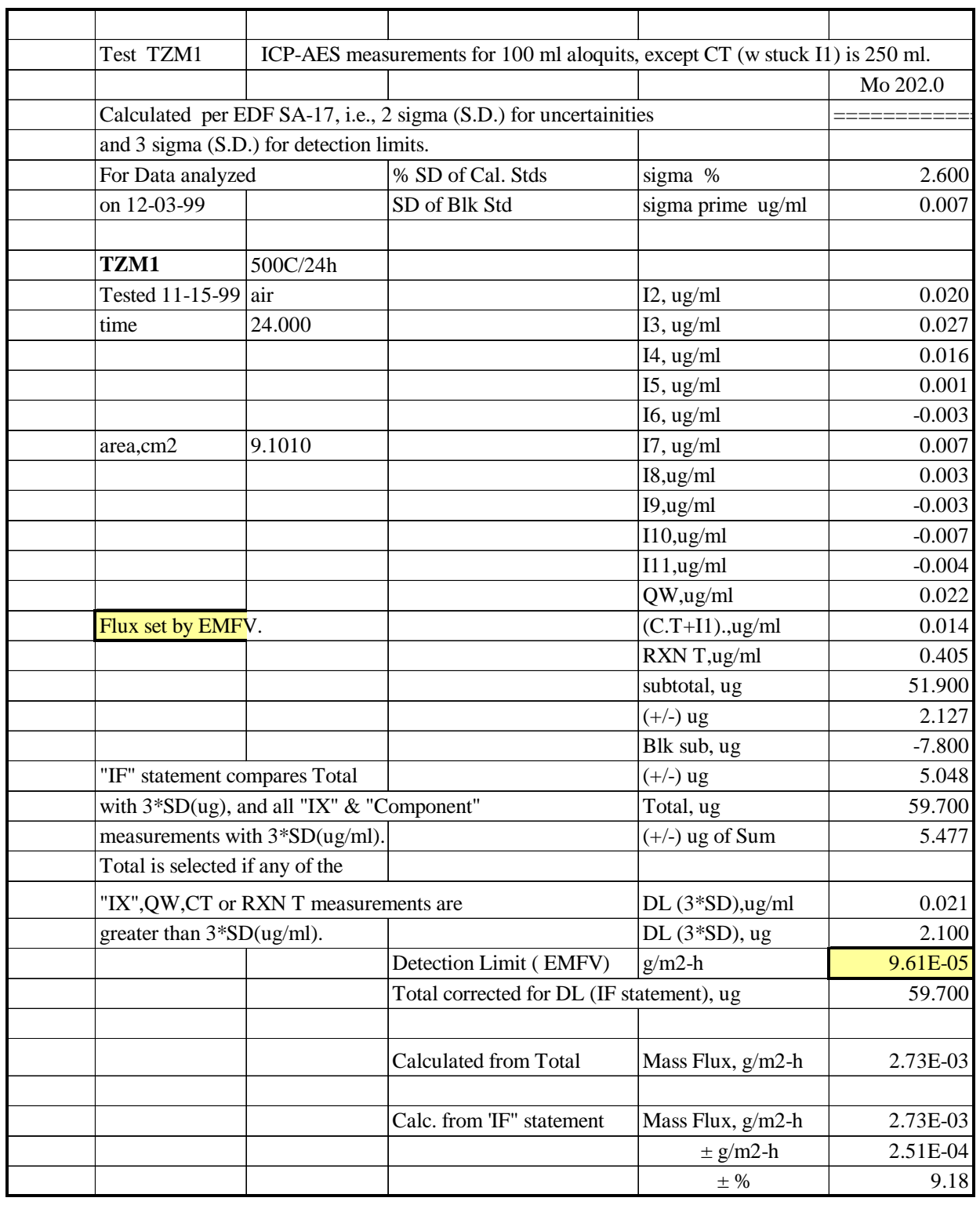


TZM1: Tested at $500^{\circ} \mathrm{C}$ for 24 hours $(1000 \mathrm{sccm}$ flow $)$

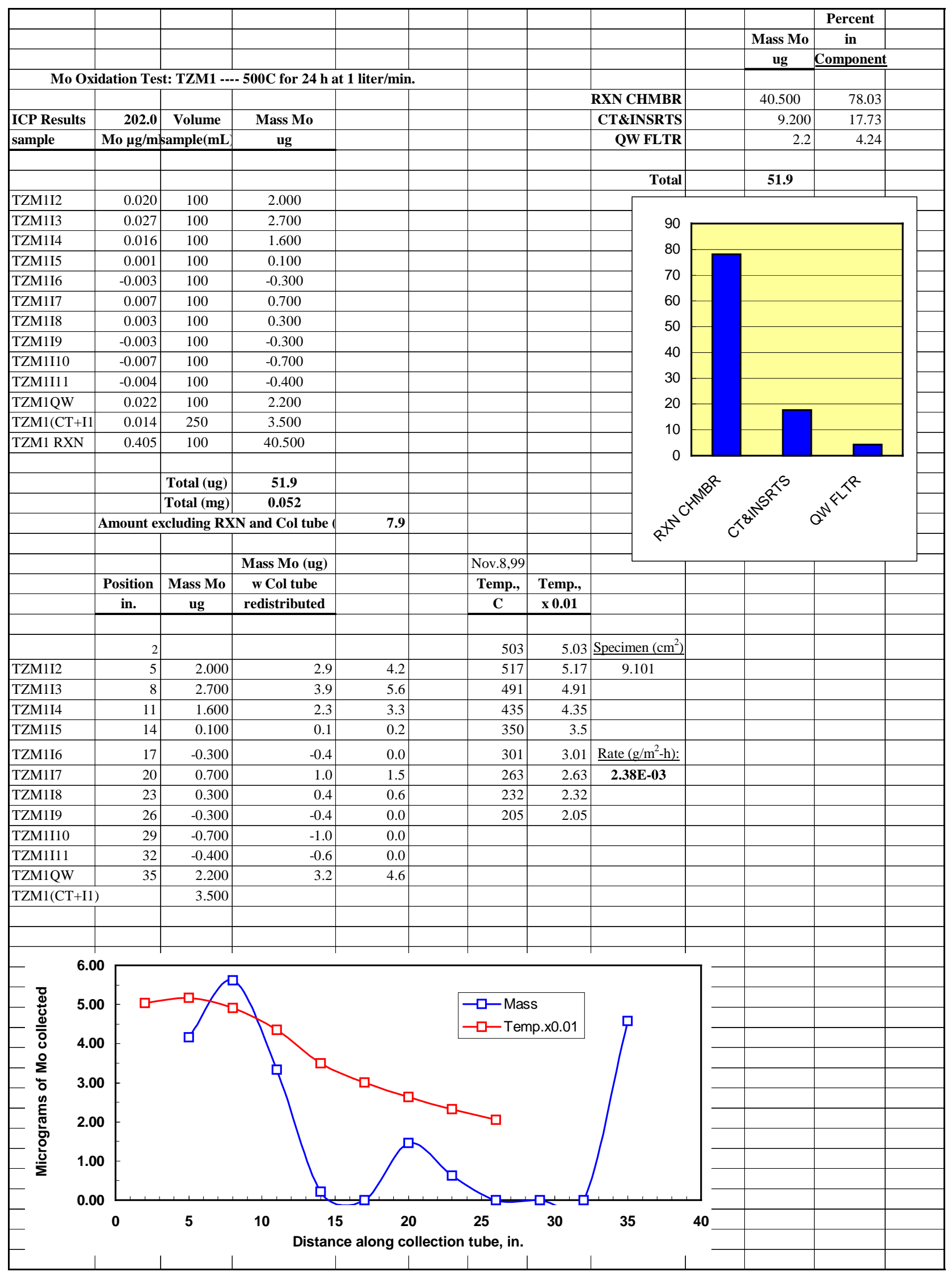


TZM16: Tested at $550^{\circ} \mathrm{C}$ for 24 hours (1000 sccm flow)

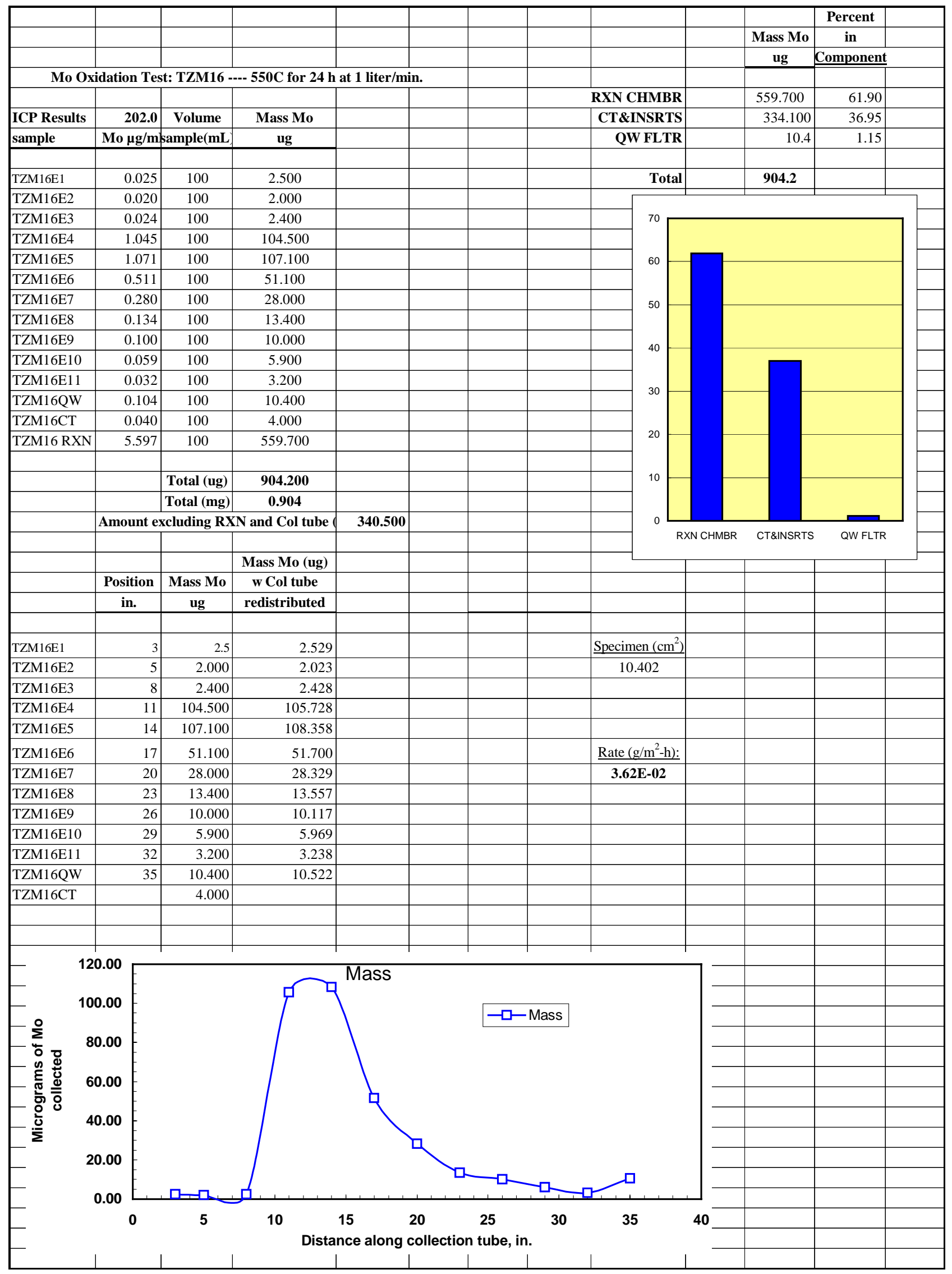


TZM11: Tested at $600^{\circ} \mathrm{C}$ for 8 hours ( $1000 \mathrm{sccm}$ flow)

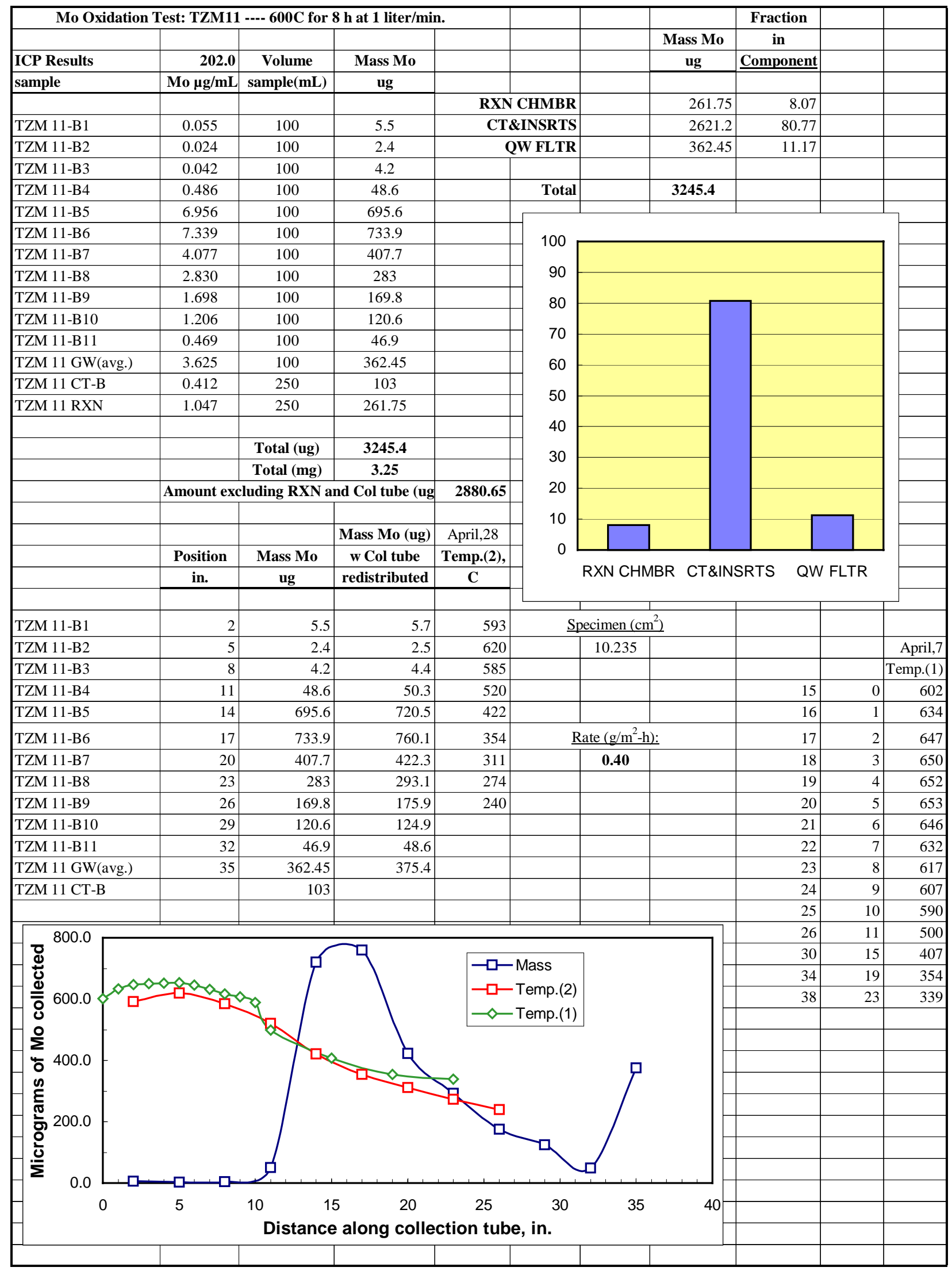


TZM7: Tested at $600^{\circ} \mathrm{C}$ for 24 hours $(1000 \mathrm{sccm}$ flow $)$

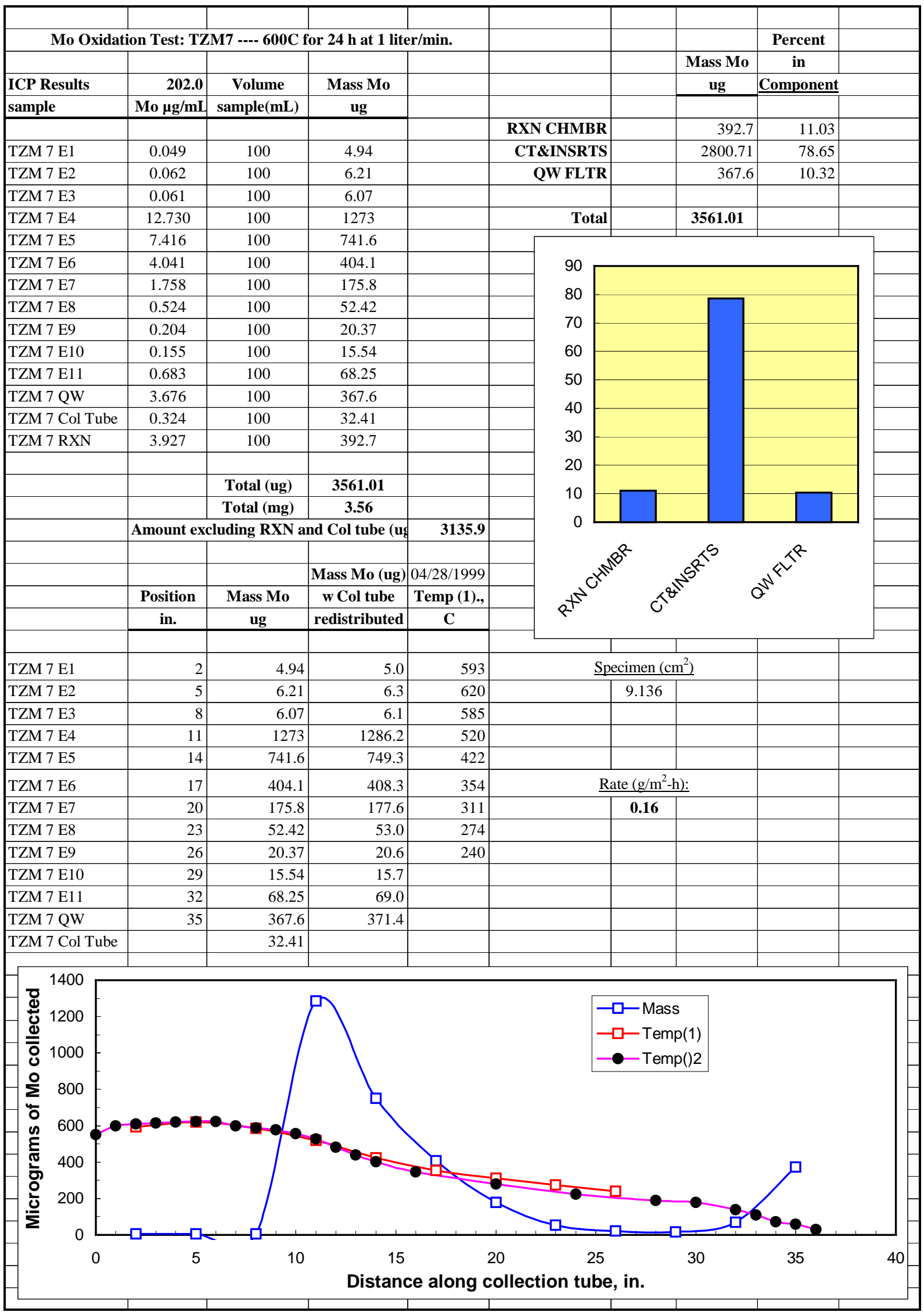


TZM8: Tested at $650^{\circ} \mathrm{C}$ for 8 hours (1000 sccm flow)

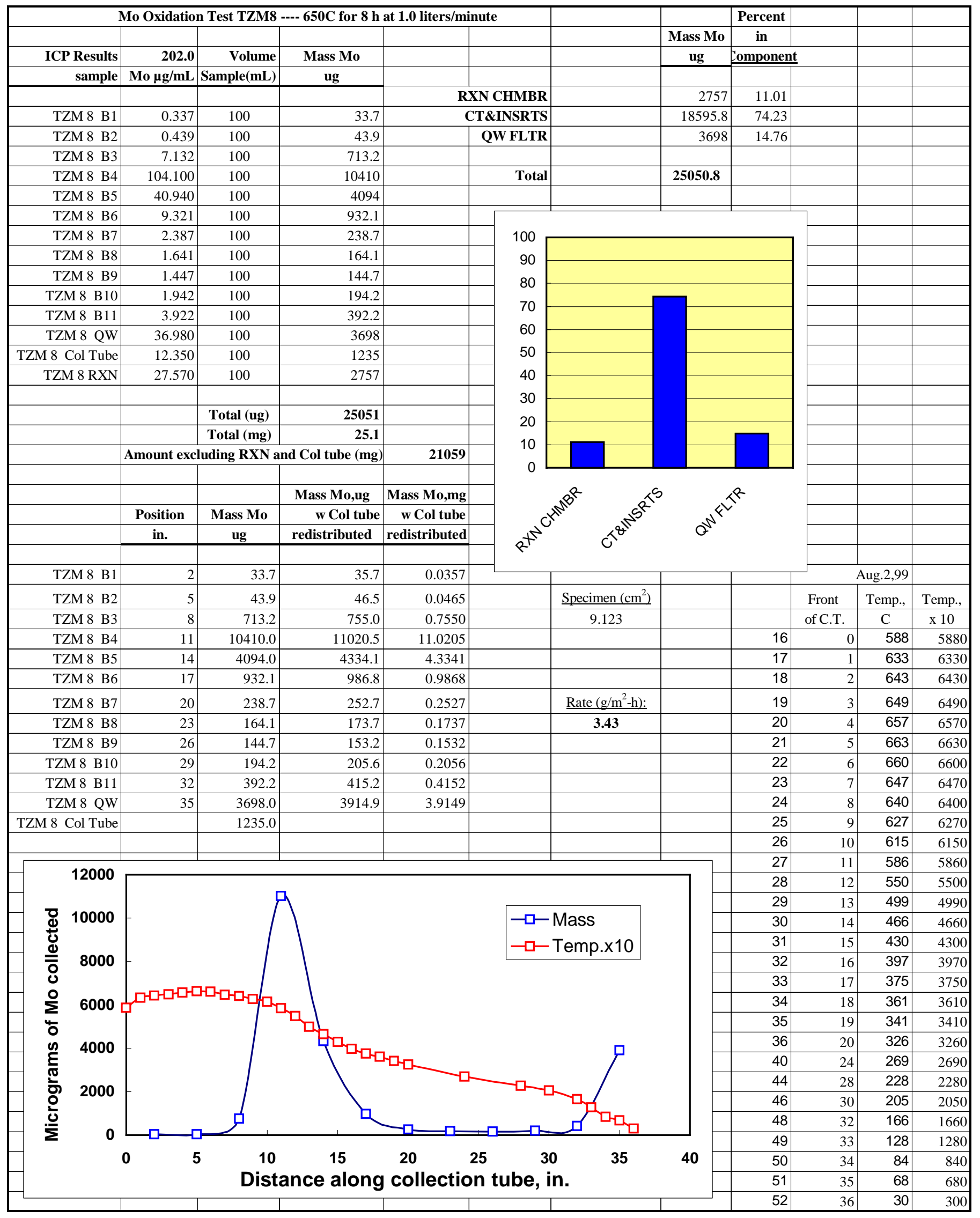


TZM4: Tested at $700^{\circ} \mathrm{C}$ for 2 hours ( 10 sccm flow)

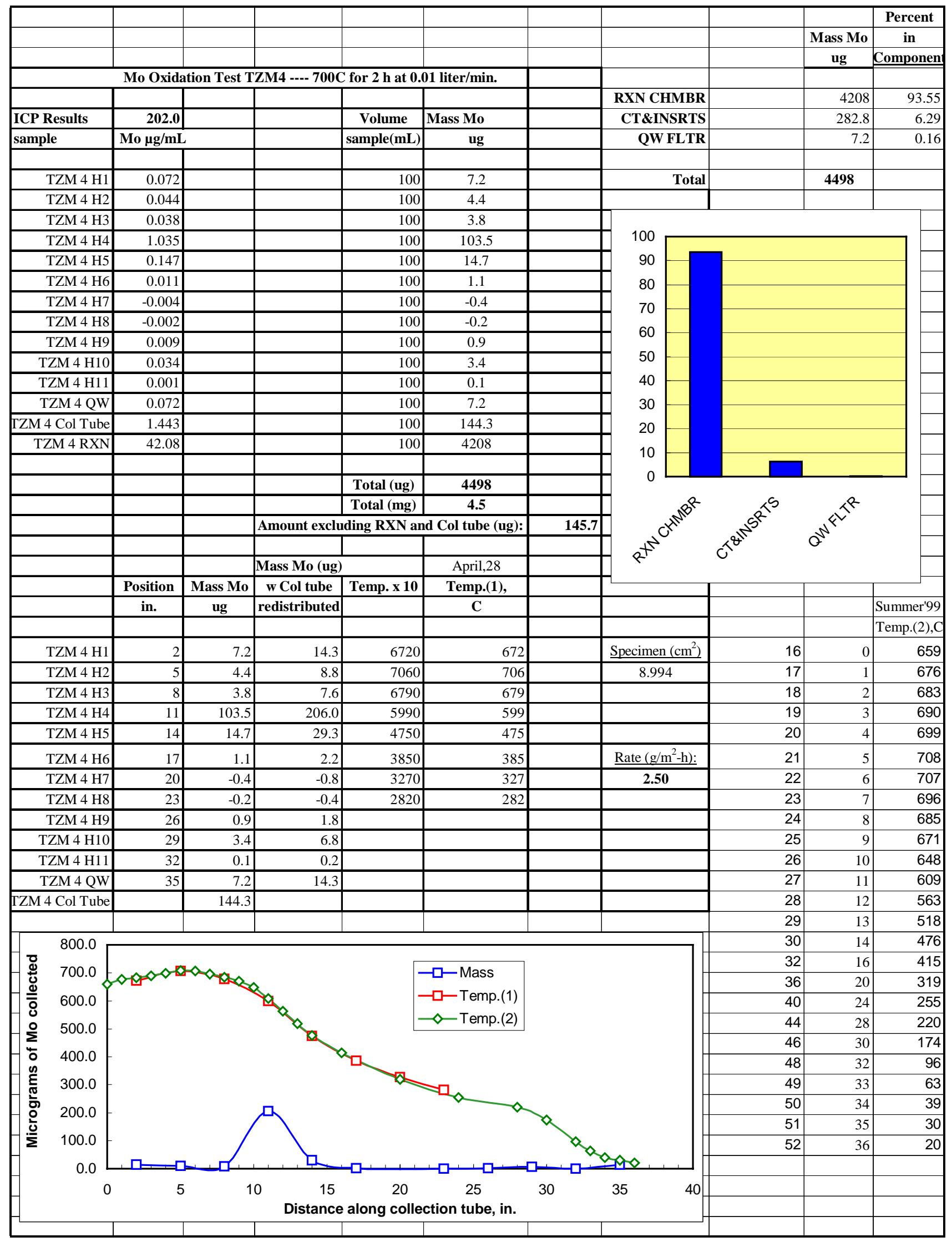


TZM17: Tested at $700^{\circ} \mathrm{C}$ for 8 hours (10 sccm flow)

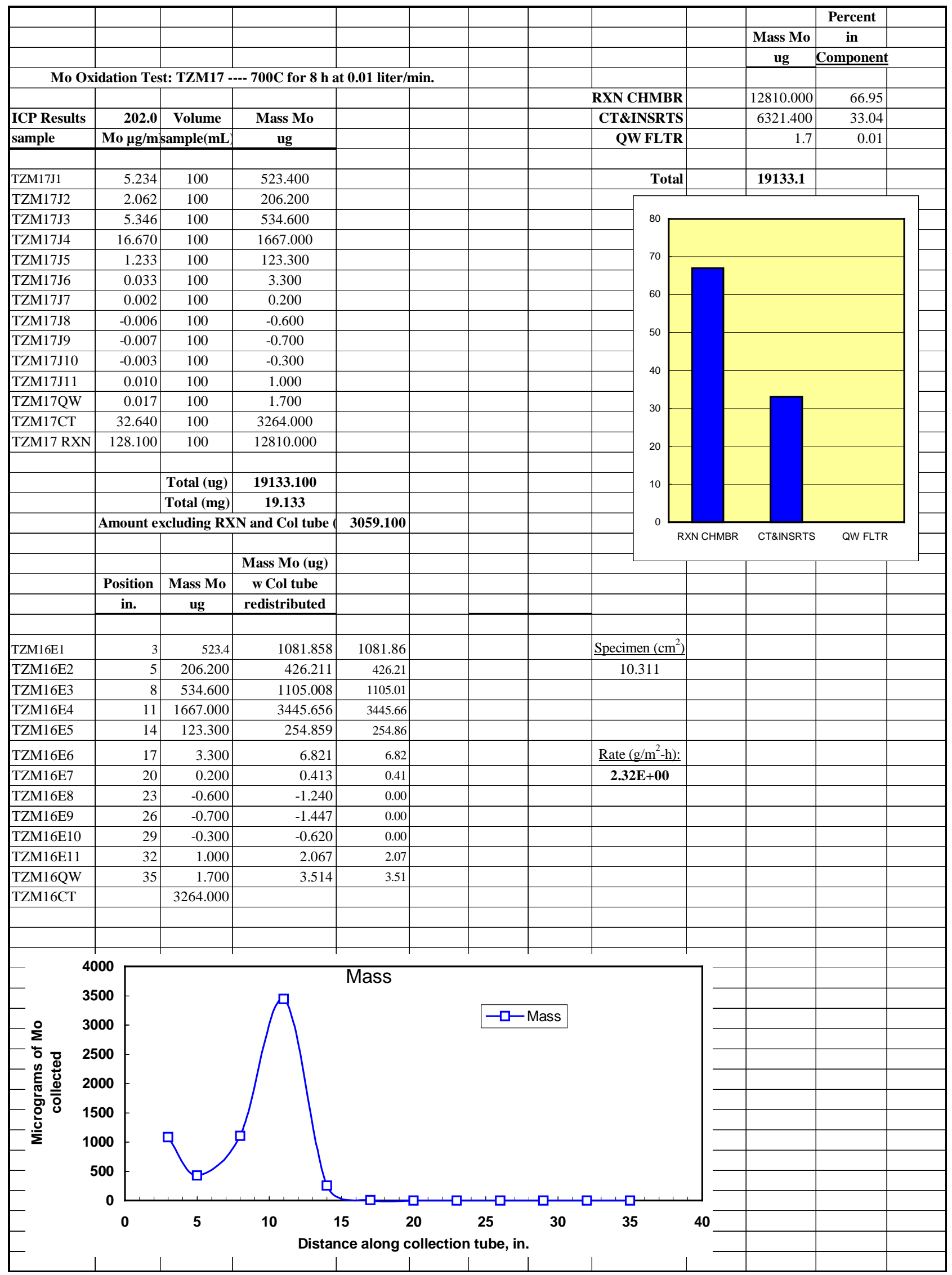




\section{TZM5: Tested at $700^{\circ} \mathrm{C}$ for 2 hours ( $50 \mathrm{sccm}$ flow)}

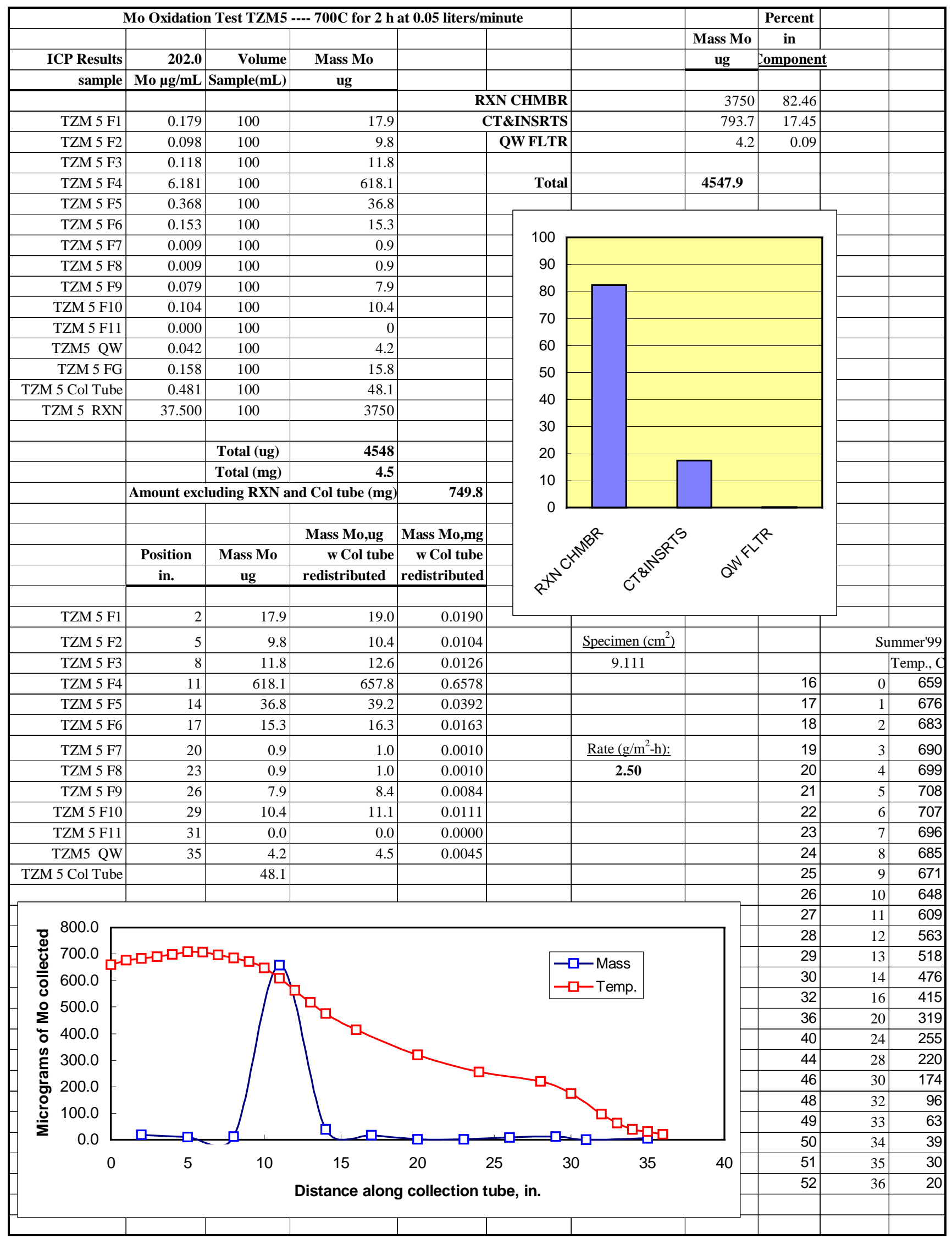




\section{TZM18: Tested at $700^{\circ} \mathrm{C}$ for 8 hours ( $50 \mathrm{sccm}$ flow)}

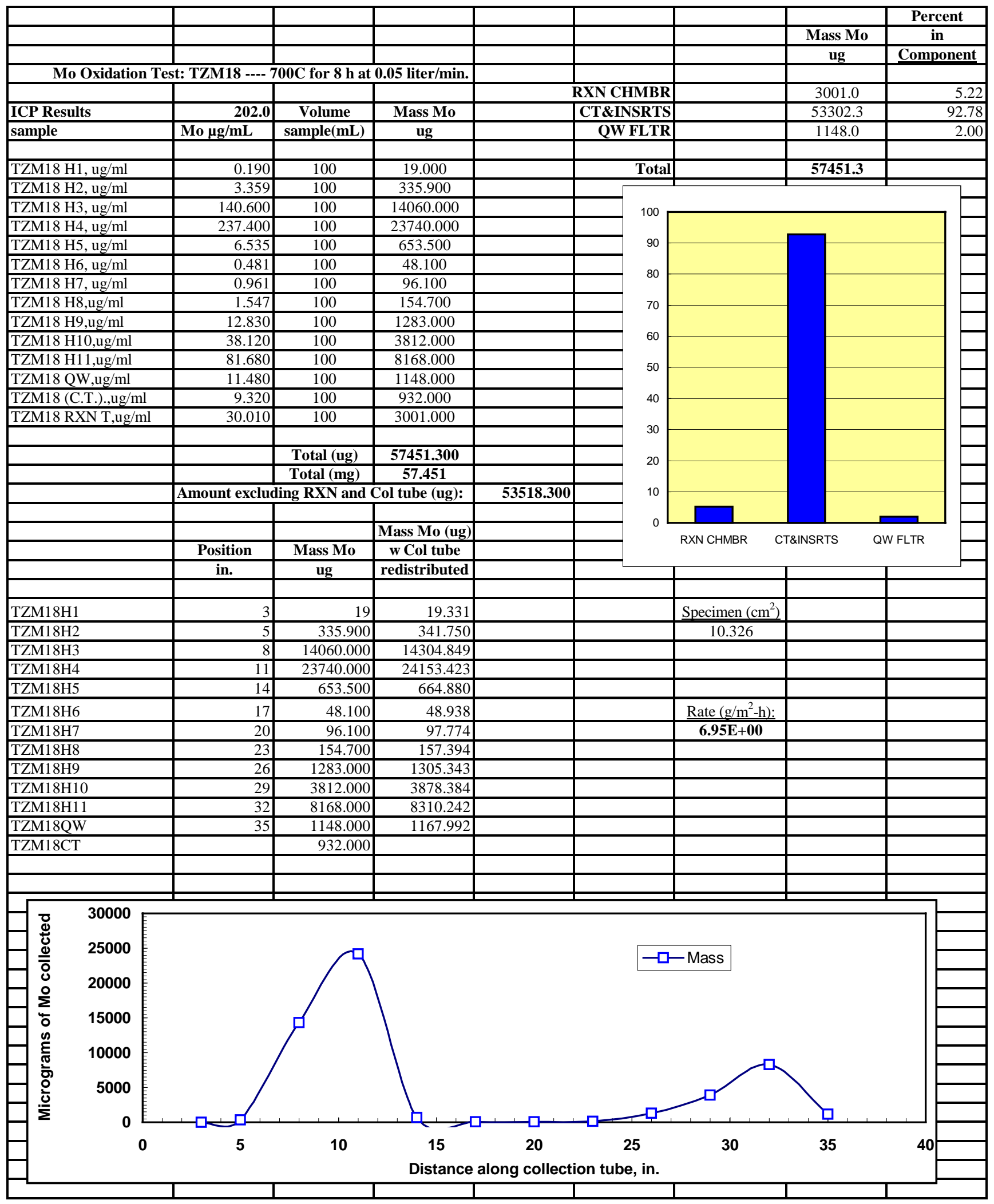


TZM10: Tested at $700^{\circ} \mathrm{C}$ for 2 hours $(100 \mathrm{sccm}$ flow $)$

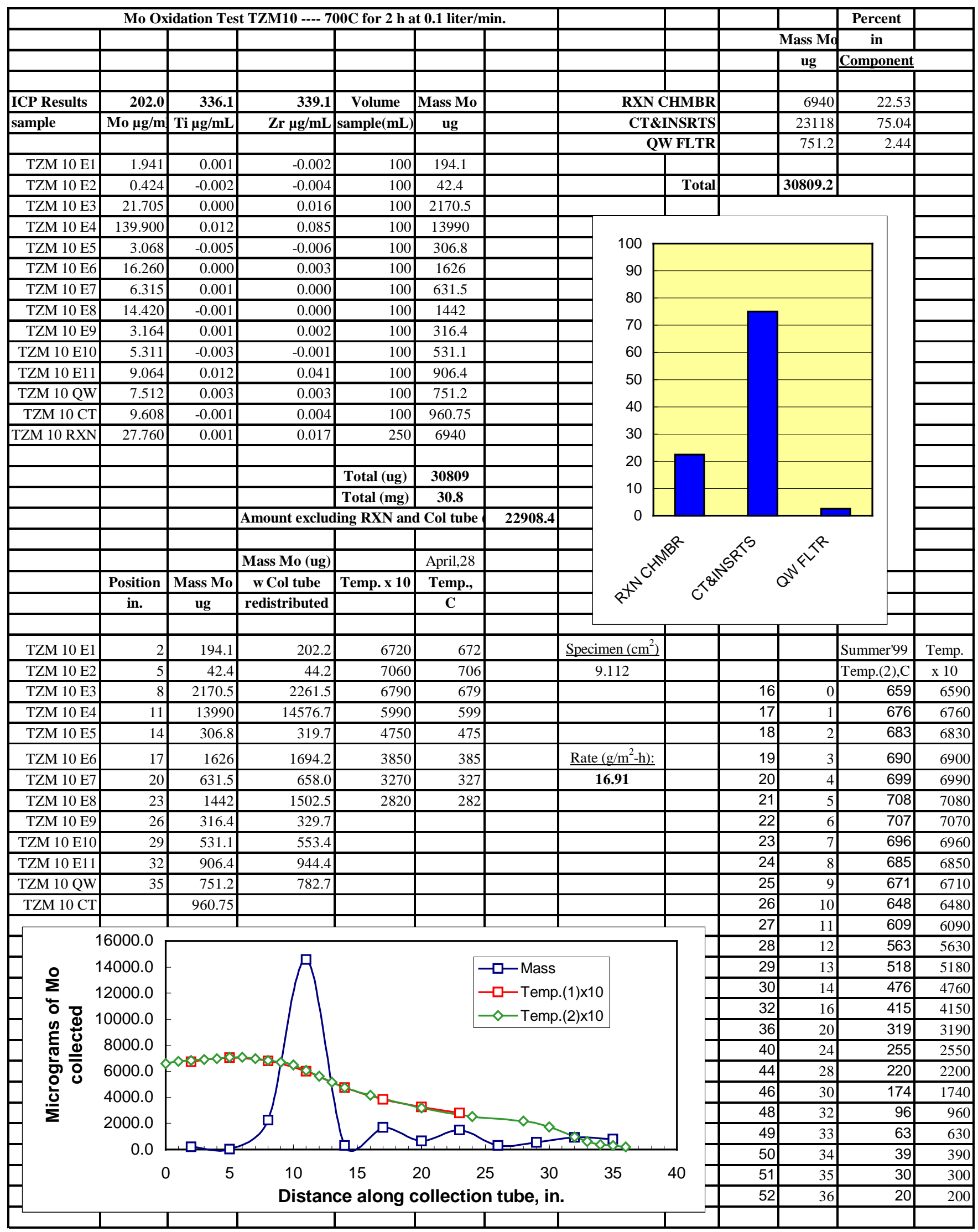




\section{TZM6: Tested at $700^{\circ} \mathrm{C}$ for 2 hours (500 sccm flow)}

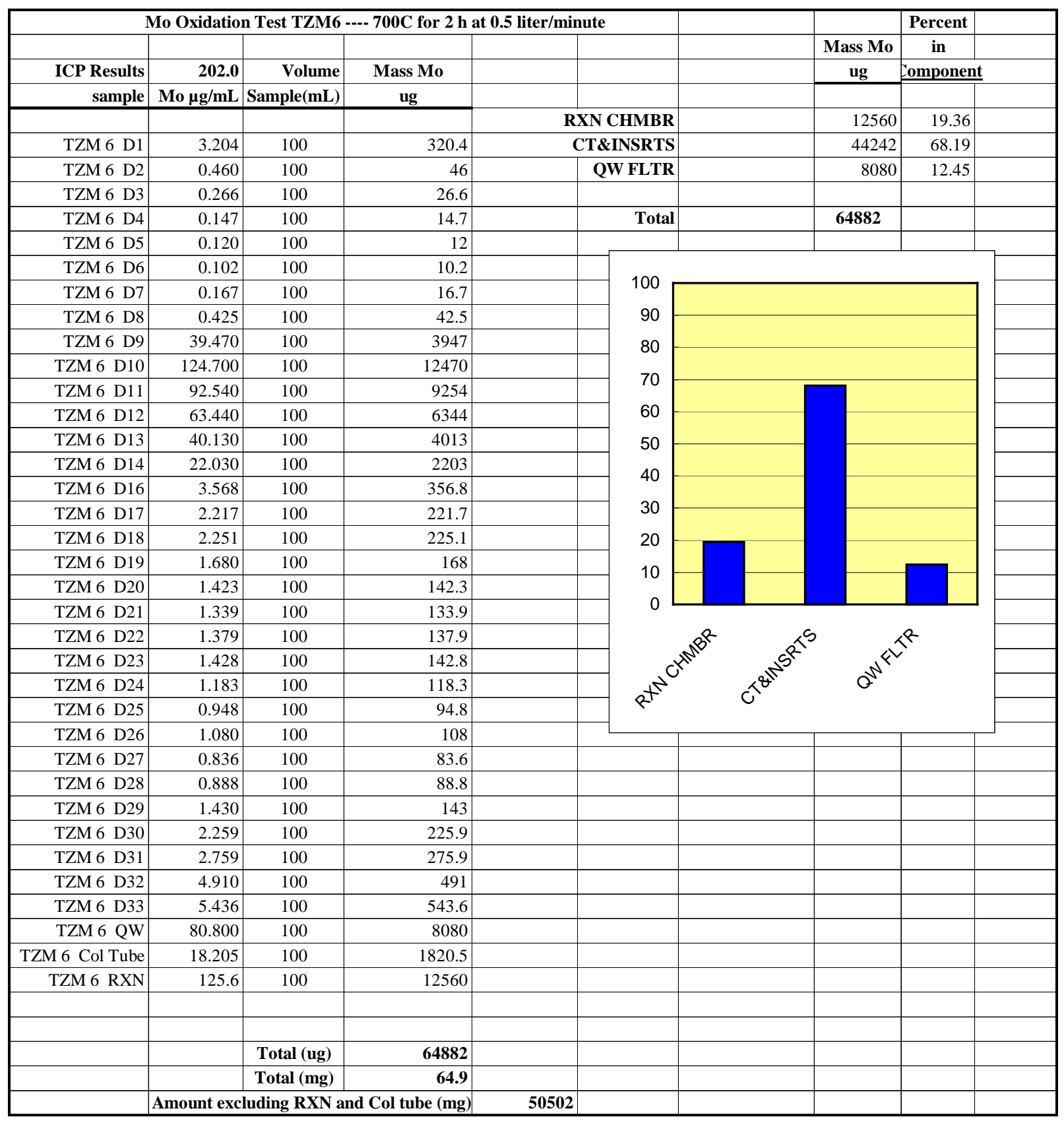


TZM6: Tested at $700^{\circ} \mathrm{C}$ for 2 hours ( $500 \mathrm{sccm}$ flow)

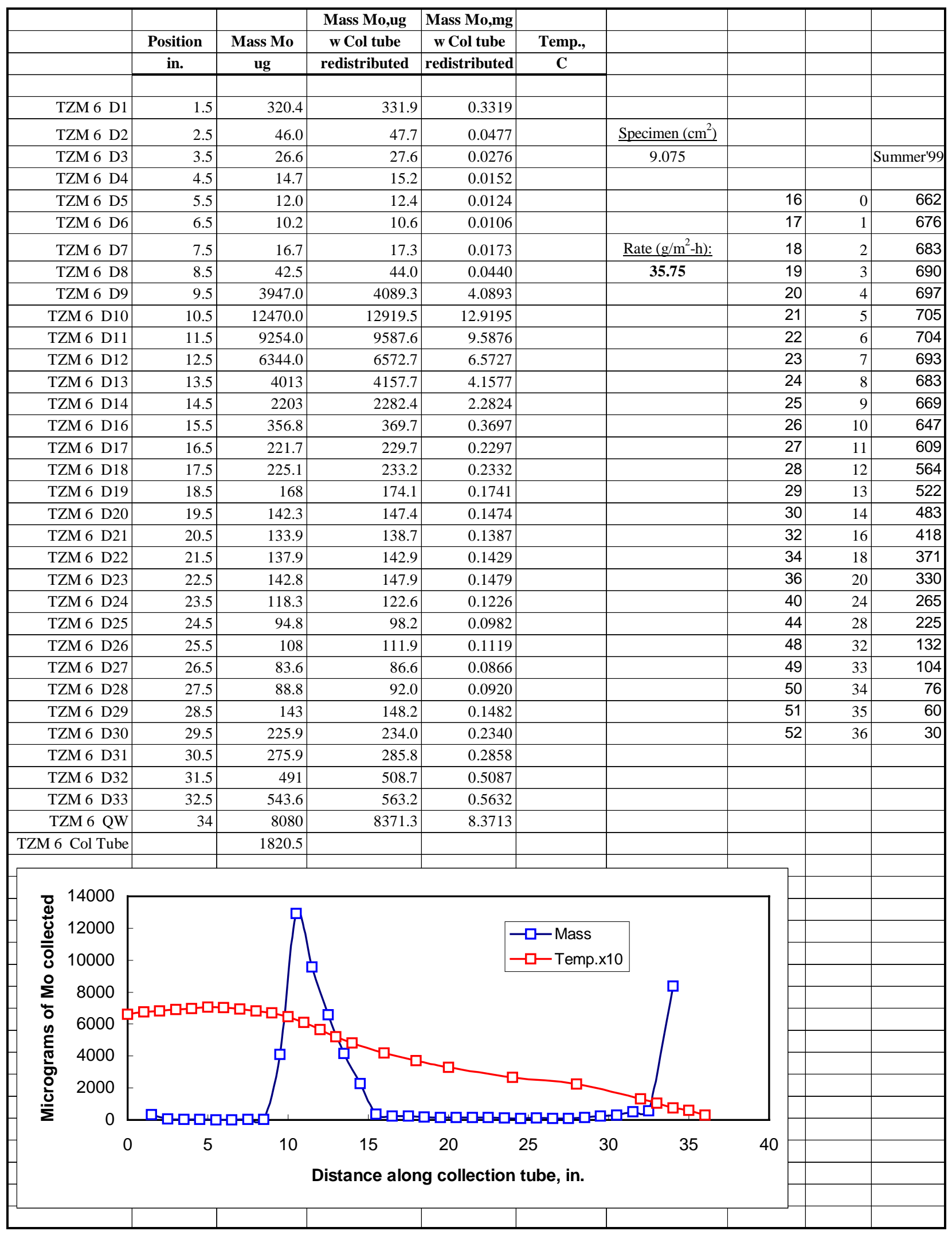


TZM12: Tested at $700^{\circ} \mathrm{C}$ for 2 hours (1000 sccm flow)

\begin{tabular}{|c|c|c|c|c|c|c|c|c|c|c|c|c|}
\hline \multicolumn{7}{|c|}{ Mo Oxidation Test TZM12 --- 700C for $2 \mathrm{~h}$ at 1.0 liters/minute } & & \multirow{2}{*}{ April,28 } & & & \multirow{2}{*}{$\begin{array}{c}\text { Percent } \\
\text { in }\end{array}$} & \\
\hline \multirow[b]{2}{*}{ ICP Results } & \multirow[b]{2}{*}{202.0} & \multirow[b]{2}{*}{ Volume } & \multirow[b]{2}{*}{ Mass Mo } & \multirow[b]{2}{*}{ Position } & \multirow{2}{*}{ Mass Mo } & \multicolumn{2}{|l|}{ Mass Mo (mg) } & & & \multirow{2}{*}{\begin{tabular}{|c|} 
Mass Mo \\
ug \\
\end{tabular}} & & \\
\hline & & & & & & w Col tube & Temp.x10 & Temp(1). & & & Component & \\
\hline sample & Mo $\mu \mathrm{g} / \mathrm{mL}$ & Sample(mL) & ug & in. & ug & redistributed & \begin{tabular}{|l|l}
$\mathbf{C}$ \\
\end{tabular} & $\mathbf{C}$ & & & & \\
\hline & & & & & & & & & RXN CHMBR & 975.25 & 1.80 & \\
\hline D1 & 0.957 & 100 & 95.7 & 1.5 & 95.7 & 98.7 & 6720 & 672 & CT\&INSRTS & 42197.7 & 77.77 & \\
\hline D2 & 0.476 & 100 & 47.6 & 2.5 & 47.6 & 49.1 & 6860 & 686 & QW FLTR & 11090 & 20.44 & \\
\hline D3 & 0.424 & 100 & 42.4 & 3.5 & 42.4 & 43.7 & 6970 & 697 & & & & \\
\hline D4 & 0.415 & 100 & 41.5 & 4.5 & 41.5 & 42.8 & 7060 & 706 & Total & 54262.95 & & \\
\hline D5 & 0.270 & 100 & 27 & 5.5 & 27 & 27.8 & 7040 & 704 & & & & \\
\hline D6 & 0.255 & 100 & 25.5 & 6.5 & 25.5 & 26.3 & 6920 & 692 & & & & \\
\hline D7 & 0.422 & 100 & 42.2 & 7.5 & 42.2 & 43.5 & 6790 & 679 & 100 & & & \\
\hline D8 & 0.513 & 100 & 51.3 & 8.5 & 51.3 & 52.9 & 6620 & 662 & 90 & & & \\
\hline D9 & 14.96 & 100 & 1496 & 9.5 & 1496 & 1542.9 & 6380 & 638 & 90 & & & \\
\hline D10 & 115.000 & 100 & 11500 & 10.5 & 11500 & 11860.8 & 5990 & 599 & 80 & & & \\
\hline D11(avg.) & 78.590 & 100 & 7859 & 11.5 & 7859 & 8105.6 & 5550 & 555 & 70 & & & \\
\hline D12 & 60.370 & 100 & 6037 & 12.5 & 6037 & 6226.4 & 5100 & 510 & & & & \\
\hline D13 & 45.970 & 100 & 4597 & 13.5 & 4597 & 4741.2 & 4750 & 475 & 60 & & & \\
\hline D14 & 34.580 & 100 & 3458 & 14.5 & 3458 & 3566.5 & 4400 & 440 & 50 & & & \\
\hline D16 & \begin{tabular}{l|l|}
17.760 \\
\end{tabular} & 100 & 1776 & 15.5 & 1776 & 1831.7 & 4130 & 413 & 40 & & & \\
\hline D17 & 1.435 & 100 & 143.5 & 16.5 & 143.5 & 148.0 & 3850 & 385 & & & & \\
\hline D18 & 0.937 & 100 & 93.7 & 17.5 & 93.7 & 96.6 & 3660 & 366 & 30 & & & \\
\hline D19 & 0.977 & 100 & 97.7 & 18.5 & 97.7 & 100.8 & 3470 & 347 & 20 & & & \\
\hline D20 & 1.030 & 100 & 103 & 19.5 & 103 & 106.2 & 3270 & 327 & 10 & & & \\
\hline D21 & 1.108 & 100 & 110.8 & 20.5 & 110.8 & 114.3 & 3080 & 308 & & & & \\
\hline D22 & 1.237 & 100 & 123.7 & 21.5 & 123.7 & 127.6 & 2950 & 295 & 0 & & & \\
\hline D23 & 1.271 & 100 & 127.1 & 22.5 & 127.1 & 131.1 & 2820 & 282 & Br & & sp & \\
\hline D24 & 1.184 & 100 & 118.4 & 23.5 & 118.4 & 122.1 & 2690 & 269 & & & & \\
\hline D25 & 1.077 & 100 & 107.7 & 24.5 & 107.7 & 111.1 & 2560 & 256 & to & & $0^{2}$ & \\
\hline D26 & 1.221 & 100 & 122.1 & 25.5 & 122.1 & 125.9 & & & & & & \\
\hline D27 & 0.981 & 100 & 98.1 & 26.5 & 98.1 & 101.2 & & & & & & \\
\hline D28 & 1.035 & 100 & 103.5 & 27.5 & 103.5 & 106.7 & & & & & & Temp.(2) \\
\hline D29 & 1.651 & 100 & 165.1 & 28.5 & 165.1 & 170.3 & & & & & Summer'99 & $\mathrm{x} 10$ \\
\hline D30 & 2.672 & 100 & 267.2 & 29.5 & 267.2 & 275.6 & & & 16 & 0 & 662 & 6620 \\
\hline D31 & 3.994 & 100 & 399.4 & 30.5 & 399.4 & 411.9 & & & 17 & 1 & 676 & 6760 \\
\hline D32 & 4.802 & 100 & 480.2 & 31.5 & 480.2 & 495.3 & & & 18 & 2 & 683 & 6830 \\
\hline D33 & 8.193 & 100 & 819.3 & 32.5 & 819.3 & 845.0 & & & 19 & 3 & 690 & 6900 \\
\hline Quartz Wool & 110.900 & 100 & 11090 & 34 & 11090 & 11437.9 & & & 20 & 4 & 697 & 6970 \\
\hline ZM12 CT-D & 16.210 & 100 & 1621 & & & & & & 21 & 5 & 705 & 7050 \\
\hline ZM12 RXN & 3.901 & 250 & 975.25 & & & & & & 22 & 6 & 704 & 7040 \\
\hline & & & & & & Specimen $\left(\mathrm{cm}^{2}\right)$ & & & 23 & 7 & 693 & 6930 \\
\hline & & Total (ug) & 54263.0 & & & \begin{tabular}{|l|}
10.343 \\
\end{tabular} & & & 24 & 8 & 683 & 6830 \\
\hline & & Total (mg) & 54.263 & & & & & & 25 & 9 & 669 & 6690 \\
\hline & & & & & & Rate $\left(\mathrm{g} / \mathrm{m}^{2}-\mathrm{h}\right):$ & & & 26 & 10 & 647 & 6470 \\
\hline & Amount exclu & uding RXN an & Col tube (u & 51666.7 & & 26.23 & & & 27 & 11 & 609 & 6090 \\
\hline & & & & & & & & & 28 & 12 & 564 & 5640 \\
\hline & 14000.0 & & & & & & & & 29 & 13 & 522 & 5220 \\
\hline & & & & & & & & & 30 & 14 & 483 & 4830 \\
\hline & 12000.0 & 0 & $\square$ & & ]-Mass & & & & 32 & 16 & 418 & 4180 \\
\hline$\stackrel{d}{=}$ & & & & & -Temp.(1 & 1) $\times 10$ & 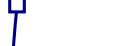 & & 34 & 18 & 371 & 3710 \\
\hline$\overline{0}$ & 10000.0 & 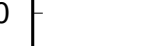 & & & —Temp.(2 & 2) $\times 10$ & & & 36 & 20 & 330 & 3300 \\
\hline 은 & 80000 & 0 & & & & & & & 40 & 24 & 265 & 2650 \\
\hline & 0000.0 & 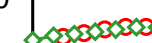 & & & & & & & 44 & 28 & 225 & 2250 \\
\hline$\overleftarrow{0}$ & 6000.0 & & & & & & & & 48 & 32 & 132 & 1320 \\
\hline & & & & & & & & & 49 & 33 & 104 & 1040 \\
\hline & 4000.0 & 0 & & & & & & & 50 & 34 & 76 & 760 \\
\hline$\frac{2}{8}$ & ח 200 & 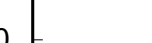 & & & & & & & 51 & 35 & 60 & 600 \\
\hline 을 & 2000.0 & 5 & & & & & & & 52 & 36 & 30 & 300 \\
\hline$\geq$ & 0.0 & ) L吅吅 & Cᄂ & חחקל & $\square[\square \square \square \square$ & 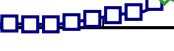 & & & & & & \\
\hline & & 0 & 10 & & 20 & 30 & & 40 & & & & \\
\hline & & & Distanc & along & collectior & n tube, in. & & & & & & \\
\hline & & & & & & & & & & & & \\
\hline
\end{tabular}


TZM9: Tested at $700^{\circ} \mathrm{C}$ for 2 hours $(2500 \mathrm{sccm}$ flow $)$

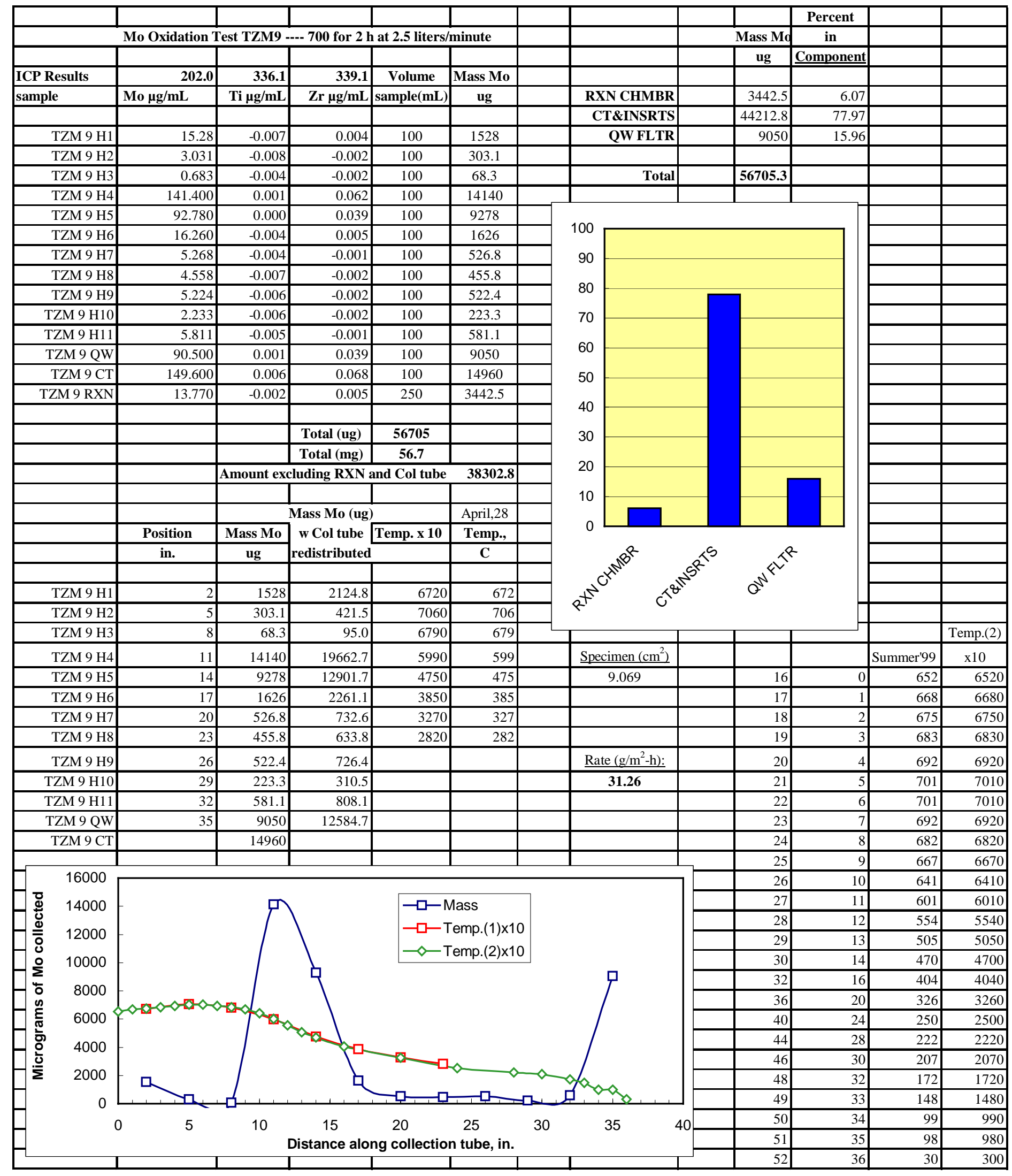


TZM3: Tested at $750^{\circ} \mathrm{C}$ for 1 hour (1000 sccm flow)

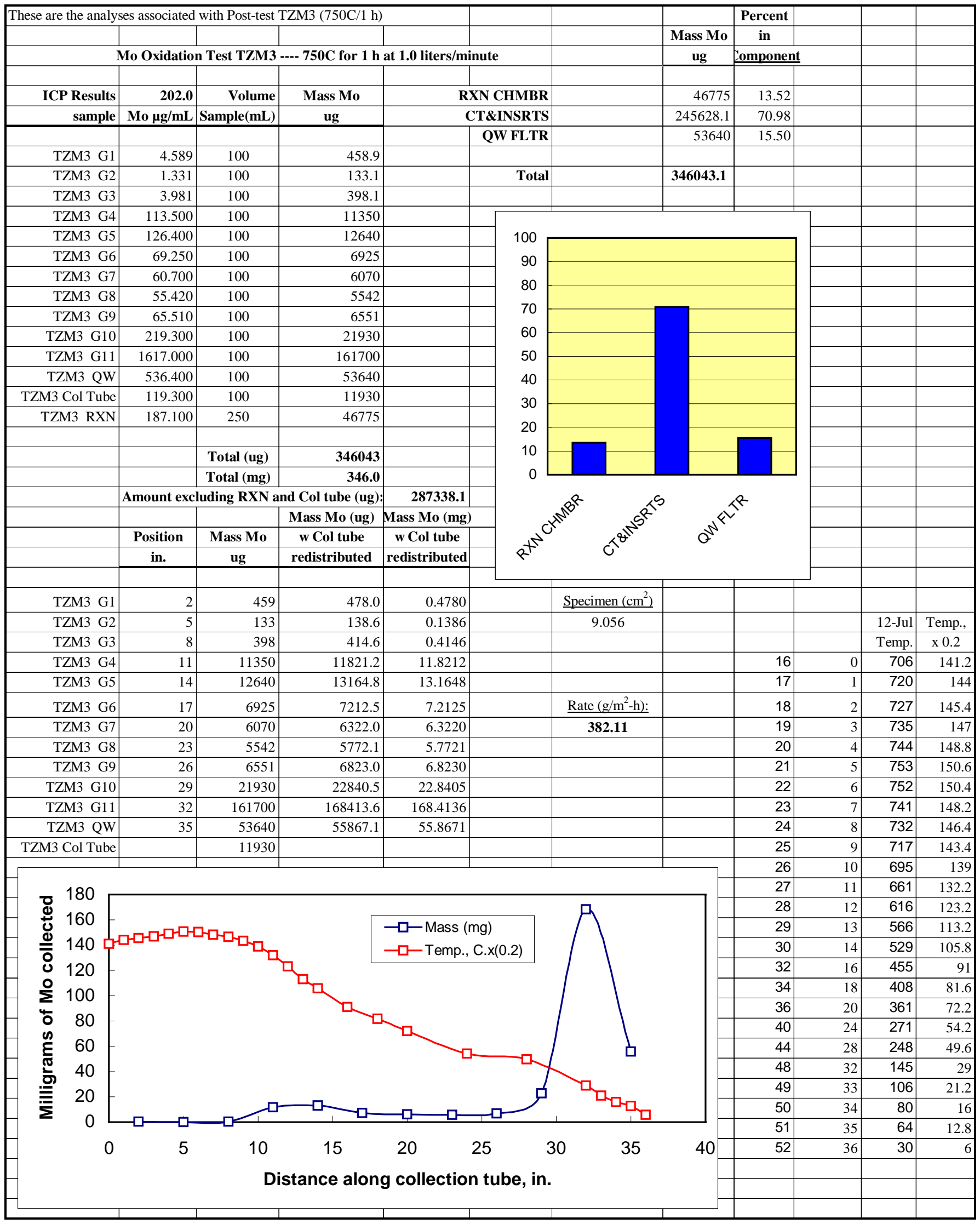




\section{TZM2: Tested at $800^{\circ} \mathrm{C}$ for 1 hour (1000 sccm flow $)$}

\begin{tabular}{|c|c|c|c|c|c|c|c|c|c|c|c|}
\hline \multicolumn{6}{|c|}{ Mo Oxidation Test TZM2 ---- 800C for $1 \mathrm{~h}$ at 1.0 liters/minute } & & & \multirow{2}{*}{\begin{tabular}{|c|} 
Percent \\
in \\
\end{tabular}} & & & \\
\hline & & & & & & & Mass Mo & & & & \\
\hline ICP Results & 202.0 & Volume & Mass Mo & & & & ug & Tomponent & & & \\
\hline sample & Mo $\mu \mathrm{g} / \mathrm{mL}$ & Sample(mL) & ug & & & & & & & & \\
\hline & & & & & XN CHMBR & & 518000 & 23.35 & & & \\
\hline TZM 2 E1 & 6.67 & 100 & 667 & & T\&INSRTS & & 1604391 & 72.32 & & & \\
\hline TZM 2 E2 & 53.78 & 100 & 5378 & & QW FLTR & & 95960 & 4.33 & & & \\
\hline TZM 2 E3 & 121.5 & 100 & 12150 & & & & & & & & \\
\hline TZM 2 E4 & 13030 & 100 & 1303000 & & Total & & 2218351 & & & & \\
\hline TZM 2 E5 & |433.6 & 100 & 43360 & & & & & & & & \\
\hline TZM 2 E6 & 522.4 & 100 & 52240 & & & & & & & & \\
\hline TZM 2 E7 & 67.48 & 100 & 6748 & & 100 & & & & & & \\
\hline TZM 2 E8 & 46.74 & 100 & 4674 & & 90 & & & & & & \\
\hline TZM 2 E9 & 55.94 & 100 & 5594 & & 80 & & & & & & \\
\hline TZM 2 E10 & 1435 & 100 & 143500 & & 70 & & & & & & \\
\hline TZM 2 QW & 959.6 & 100 & 95960 & & 10 & & & & & & \\
\hline TZM 2 Col Tube & 270.8 & 100 & 27080 & & 60 & & & & & & \\
\hline TZM 2 RXN & 2072 & 250 & 518000 & & 50 & & & & & & \\
\hline & & & & & 40 & & & & & & \\
\hline & & & & & & & & & & & \\
\hline & & Total (ug) & 2218351 & & 30 & & & & & & \\
\hline & & Total (mg) & 2218.4 & & 20 & & & & & & \\
\hline & Amount excl & uding $\mathbf{R X N}$ ar & nd Col tube (mg) & 1673271 & 10 & & & & & & \\
\hline & & & & & & & & & & & \\
\hline & & & Mass Mo,ug & Mass Mo,mg & & & & & & & \\
\hline & Position & Mass Mo & w Col tube & w Col tube & & & & & & & \\
\hline & in. & ug & redistributed & redistributed & & & & & & & \\
\hline & & & & & & & & & & & \\
\hline TZM 2 E1 & 2 & 667.0 & 677.8 & 0.6778 & & & & & & & \\
\hline TZM 2 E2 & 5 & 5378.0 & 5465.0 & 5.4650 & & & & & & July,12 & Temp. \\
\hline TZM 2 E3 & 8 & 12150.0 & 12346.6 & 12.3466 & & Specimen $\left(\mathrm{cm}^{2}\right)$ & & & & Temp. & $\mathrm{x} 2$ \\
\hline TZM 2 E4 & 11 & 1303000.0 & 1324087.6 & 1324.0876 & & 9.15 & & 16 & 0 & 777 & 1554 \\
\hline TZM 2 E5 & 14 & 43360.0 & 44061.7 & 44.0617 & & & & 17 & 1 & 790 & 1580 \\
\hline TZM 2 E6 & 17 & 52240.0 & 53085.4 & 53.0854 & & & & 18 & 2 & 793 & 1586 \\
\hline TZM 2 E7 & 20 & 6748.0 & 6857.2 & 6.8572 & & Rate $\left(\mathrm{g} / \mathrm{m}^{2}-\mathrm{h}\right)$ : & & 19 & 3 & 801 & 1602 \\
\hline TZM 2 E8 & 23 & 4674.0 & 4749.6 & 4.7496 & & 2424.43 & & 20 & 4 & 807 & 1614 \\
\hline TZM 2 E9 & 26 & 5594.0 & 5684.5 & 5.6845 & & & & 21 & 5 & 815 & 1630 \\
\hline TZM 2 E10 & 29 & 143500.0 & 145822.4 & 145.8224 & & & & 22 & 6 & 811 & 1622 \\
\hline TZM 2 QW & 35 & 95960.0 & 97513.0 & 97.5130 & & & & 23 & 7 & 797 & 1594 \\
\hline TZM 2 Col Tube & & 27080.0 & & & & & & 24 & 8 & 785 & 1570 \\
\hline & & & & & & & & 25 & 9 & 770 & 1540 \\
\hline & ) & & & & & & & 26 & 10 & 748 & 1496 \\
\hline$\Phi 1600$ & ك-ם & סחיח- & & & & & & 27 & 11 & 713 & 1426 \\
\hline$\stackrel{\Phi}{=} 1400$ & ( & & & & $-\square-1$ & Mass (mg) & & 28 & 12 & 666 & 1332 \\
\hline $\begin{array}{l}\overline{\bar{O}} \\
\end{array}$ & & & & & $-\square-7$ & emp.,Cx(2) & & 29 & 13 & 624 & 1248 \\
\hline$\stackrel{0}{2} 1000$ & & & & & & & & 30 & 14 & 587 & 1174 \\
\hline$\sum 1000$ & 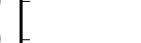 & & & & & & & 32 & 16 & 522 & 1044 \\
\hline $\begin{array}{l}\overline{0} \\
\text { s }\end{array}$ & & & & & & & & 34 & 18 & 466 & 932 \\
\hline$\frac{E}{\sigma} 600$ & & & & & & & & 36 & 20 & 417 & 834 \\
\hline 흔 400 & 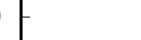 & & & & & & & 40 & 24 & 344 & 688 \\
\hline 言 200 & & & & & & & & 44 & 28 & 296 & 592 \\
\hline $\begin{array}{ll}\Sigma & 0\end{array}$ & $\square$ & & & 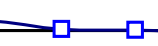 & & & & 48 & 32 & 175 & 350 \\
\hline & 0 & 10 & 15 & 20 & 25 & 35 & 40 & 49 & 33 & 130 & 260 \\
\hline & & & Dictanco aln & colloction & tuhe in & & & 50 & 34 & 90 & 180 \\
\hline & & & Distance alo & ong collection & & & & 51 & 35 & 72 & 144 \\
\hline & $\square$ & $\mathrm{T}$ & & I & & & & 52 & 36 & 30 & 60 \\
\hline
\end{tabular}

